TATIANA MAZZA DA SILVA

\title{
GRAMATICALIZAÇÃO DE JUNTIVOS ADVERSATIVOS NA HISTÓRIA DO PORTUGUÊS
}


TATIANA MAZZA DA SILVA

\section{GRAMATICALIZAÇÃO DE JUNTIVOS ADVERSATIVOS NA HISTÓRIA DO PORTUGUÊS}

Dissertação apresentada para obtenção do título de Mestre em Estudos Linguísticos, área de Análise Linguística junto ao Programa de Pós-Graduação em Estudos Linguísticos do Instituto de Biociências, Letras e Ciências Exatas da Universidade Estadual Paulista "Júlio de Mesquita Filho", Câmpus de São José do Rio Preto.

Bolsa: FAPESP (processo nº 08/52009-3)

\section{BANCA EXAMINADORA}

Prof. Dr. Sebastião Carlos Leite Gonçalves Professor Assistente Doutor UNESP - São José do Rio Preto Orientador

Prof $^{\mathrm{a}}$. Dr ${ }^{\mathrm{a}}$. Mariângela Rios de Oliveira Professor Doutor Universidade Federal Fluminense

Prof $^{a}$. Dra . Gisele Cássia de Sousa Professor Assistente Doutor UNESP - São José do Rio Preto 
Silva, Tatiana Mazza da.

Gramaticalização de juntivos adversativos na história do português / Tatiana Mazza da Silva. - São José do Rio Preto : [s.n.], 2010.

$174 \mathrm{f} . ; 30 \mathrm{~cm}$.

Orientador: Sebastião Carlos Leite Gonçalves

Dissertação (mestrado) - Universidade Estadual Paulista, Instituto de Biociências, Letras e Ciências Exatas

1. Linguística histórica. 2. Gramaticalização. 3. Conjunção adversativa. I. Gonçalves, Sebastião Carlos Leite. II. Universidade Estadual Paulista, Instituto de Biociências, Letras e Ciências Exatas. III. Título.

$$
\text { CDU - 81-112 }
$$

Ficha catalográfica elaborada pela Biblioteca do IBILCE Campus de São José do Rio Preto - UNESP 


\section{DEDICATÓRIA}

Ao meu vovô Mazza (in memorian) e a minha filha, Maria Eduarda, Luzes da minha vida 


\section{AGRADECIMENTOS}

A Deus e a Nossa Senhora por sempre terem me dado a força necessária para seguir.

Ao Prof. Dr. Sebastião Carlos Leite Gonçalves, pela orientação exemplar e pela amizade que construímos ao longo desses dois anos de trabalho. A minha eterna gratidão, pela confiança depositada em meu trabalho.

Ao meu vovô Mazza, mesmo não estando mais entre nós, ensinou-me a acreditar que o querer é um passo para o poder, basta persistir.

Aos meus pais, que, na simplicidade, tentaram entender a minha escolha profissional. Obrigada por sempre darem as condições necessárias para eu seguir essa escolha.

À Maria Eduarda, minha amada filha, pelas vezes que me faz esquecer "um pouco" do trabalho e voltar para o mundo do Era uma vez, num reino muito distante...

A todos os professores da graduação que sempre me incentivaram a seguir pelos caminhos da Linguística.

À professora Gisele, pelo exemplo de professora, pela amizade e pelas sugestões que sempre fez ao meu trabalho, especialmente, no exame de qualificação e na defesa.

À professora Anna Flora, pela amizade, pelas palavras sábias nos momentos difíceis e pela contribuição no exame de qualificação.

À Profa. Dra. Mariângela Rios, pelas contribuições muito sábias feitas na defesa do trabalho.

Ao Prof. Dr. Américo Venâncio Lopes Filho, da UFBa, por ter me enviado o corpus do BITPROHPOR e pelas discussões sobre o rumo da pesquisa diacrônica.

À Profa. Dra. Angélica Rodrigues, à Profa. Dra. Maria Luiza Braga, à Profa. Dra. Mariângela Rios e à Profa. Dra. Maria Helena de Moura Neves que, durante as discussões de congressos, fizeram grandes contribuições para o desenvolvimento dessa pesquisa. 
Aos meus amigos de graduação, Aline, Fernando Henrique, Guilherme, Jaqueline, Natália Feres e Sheila, que sempre estiveram ao meu lado, aguentando as minhas neuroses acadêmicas.

Aos amigos de pós-graduação, Ana Helena, Ana Maria, Carla Fusca, Cássio, Danti, Flávia, Maura, Michel, Marcos, Mircia, Viviane, pela amizade, pelas sugestões ao meu trabalho e por sempre ter tornado as viagens aos congressos mais agradáveis.

Ao amigo-irmão Vinicius, pelos cafés-terapias, pelas horas de conversas, pelas viagens, pela vibração em cada conquista minha. Enfim, obrigado por ser o irmão mais velho que eu sempre desejei ter.

Aos amigos Ana Maria, André, Angélica, Beatriz, Naty, Renata e Wilson, amigos, que sempre estiveram ao meu lado me apoiando nos momentos que foram precisos, mesmo não entendendo do meu trabalho.

Ao lieber Paul, que, no momento mais crítico dessa dissertação, segurou comigo as pontas e me mostrou que era apenas uma etapa a ser cumprida. Danke, mein Schatz!

Aos funcionários da Seção de Pós-Graduação do IBILCE.

À Fundação de Amparo à Pesquisa do Estado de São Paulo, FAPESP, pela bolsa concedida. 
SAÚDE

Apesar, contudo, todavia, mas, porém

As águas vão rolar

Rita Lee 
SILVA, Tatiana Mazza da. Gramaticalização de juntivos adversativos na história do português. 2010. 174f. Dissertação (Mestrado em Estudos Linguísticos) - Instituto de Biociências, Letras e Ciências Exatas. Universidade Estadual Paulista.

\section{RESUMO}

O objetivo geral desse trabalho é investigar a mudança sintático-semântico-pragmática dos juntivos porém, contudo, todavia, entretanto e no entanto, conjuntamente, sob a perspectiva da gramaticalização, a fim de buscar a comprovação da hipótese de uma trajetória do tipo advérbio > conjunção, por meio de análises contextuais que expliquem o surgimento do uso conjuncional adversativo na história do português. Adotamos, nesse trabalho, a concepção mais clássica de gramaticalização, a qual, segundo Hopper e Traugott (2003), prevê que itens lexicais podem, em determinados contextos, passar a assumir funções gramaticais ou, se já gramaticalizados, continuar a desenvolver novas funções gramaticais. Esse processo envolve pragmatização crescente de significados (mudança semântica) e recategorização do item (mudança sintática). A investigação das mudanças pelas quais passaram os itens por nós analisados baseia-se em um corpus composto de textos históricos e textos do português contemporâneo, compreendendo os períodos arcaico (século XIII a XV), moderno (XVI e XVII) e contemporâneo (XVIII a XXI).

Considerando fatores de ordem semântica, sintática e pragmática na recomposição da trajetória de gramaticalização de cada um dos itens, podemos atestar que seus funcionamentos adversativo e conjuncional emergiram em diferentes momentos da história do português, fato que, no português contemporâneo, os colocam em diferentes pontos em uma escala de gramaticalização, a saber: porém > todavia, contudo > entretanto > no entanto.

Palavras-chave: linguística histórica; gramaticalização; conjunção adversativa. 
SILVA, Tatiana Mazza da. Grammaticalization of adversative juntives in the Portuguese history. 2010. 174f. Dissertação (Mestrado em Estudos Linguísticos) - Instituto de Biociências, Letras e Ciências Exatas. Universidade Estadual Paulista.

\begin{abstract}
The aim of this dissertation is to investigate the syntactic, semantic, pragmatic change of the juntives porém, contudo, todavia, entretanto and no entanto under the perspective of grammaticalization in order to search for the evidence of the hypothesis of a trajectory of the kind adverb > conjunction through contextual analysis which can explain the origin of the adversative use as a conjunction in the history of Portuguese. We adopted, in this paper, the most classical concept of grammaticalization, which, according to Hopper and Traugott (2003), foresees that lexical items can, in some contexts, assume grammatical functions or continue to develop new ones. This process involves growing pragmatization of meanings (semantic change) and recategorization of the item (syntactic change). The investigation of the juntives changes analyzed in this paper is based on a corpus composed of historical texts and texts of contemporary Portuguese, which comprehends the archaic (century XIII to XV), modern (XVI and XVII) and contemporary (XVIII to XXI) periods.

Considering the semantic, syntactic and pragmatic factors in the reconstruction of the trajectory of grammaticalization of each one of the juntives, we can attest that the adversative and conjunctional functioning emerged in different moments in the history of Portuguese, a fact that, in contemporary Portuguese, put them in different points on the grammaticalization scale, which is: porém > todavia, contudo $>$ entretanto $>$ no entanto.
\end{abstract}

Keywords: historical linguistics; grammaticalization; adversative conjunction. 


\section{LISTA DE QUADROS, TABELAS E GRÁFICOS}

\section{LISTA DE QUADROS}

Quadro 1: Estágios de evolução da língua (Humboldt (1822, apud HOPPER \&TRAUGOTT, 1993, p. 18-19) ..................................... 20

Quadro 2: Conceitos lexicais e conceitos gramaticais .............................................. 25

Quadro 3: Classificação das formas de discurso. (GONÇALVES et al., 2007)

Quadro 4: Correlação entre categorias metafóricas, classes de palavras e tipos de constituintes (HEINE et al., 1991, p.53-54) ...................... 35

Quadro 5: Diferença entre metonímia e metáfora. (GONÇALVES et al., 2007, p.40)

Quadro 6: Matriz de traços semânticos que se aplicam aos diferentes advérbios juntivos ...

Quadro 7: Fatores identificadores de usos adverbiais e conjuncionais dos itens a serem pesquisados

\section{LISTA DE TABELAS}

Tabela 1: Frequência geral dos itens de XIII a XXI

p.

Tabela 2: Frequência token e type totais de contudo na história do português (séc. XIV a XXI)

Tabela 3: Frequência das posições sintáticas de contudo na história do português (séc. XIV a XXI) .

Tabela 4: $\quad$ U uso de contudo em presença de elemento de negação ao longo da história do português (séc. XIV a XXI)

Tabela 5: Estratégias argumentativas de contudo (adversativo) do século XIV ao XXI

Tabela 6: Frequência token e type totais de todavia na história do português (séc. XIII a XXI)

Tabela 7: Frequência das posições sintáticas de todavia na história do português (séc. XIII a XXI)

Tabela 8: O uso de todavia em presença de elemento de negação ao longo da história do português (séc. XIII a XXI)

Tabela 9: Estratégias argumentativas de todavia (adversativo) do século XIII ao XXI

Tabela 10: Frequência token e type totais de entretanto na história do português (séc. XVI a XXI)

Tabela 11: Frequência das posições sintáticas de entretanto na história do português (séc. XVI a XXI)

Tabela 12: $\mathrm{O}$ uso de entretanto em presença de elemento de negação ao longo da história do português (séc. XVI a XXI) .

Tabela 13: Estratégias argumentativas de entretanto (adversativo) do século $\mathrm{XVI}$ ao XXI

Tabela 14: Frequência token e type totais de no entanto na história do português (séc. XIII a XXI)

Tabela 15: Frequência das posições sintáticas de no entanto na história do português (séc. XIII a XXI) 
Tabela 16: O uso de no entanto em presença de elemento de negação ao longo da história do português (séc. XIII a XXI)

Tabela 17: Estratégias argumentativas de no entanto (adversativo) dos séculos XX e XXI

Tabela 18: Frequência token e type totais de porém na história do português (séc. XIII a XXI)

Tabela 19: Frequência das posições sintáticas de porém na história do português (séc. XIII a XXI)

Tabela 20: $\mathrm{O}$ uso de porém em presença de elemento de negação ao longo da história do português (séc. XVI a XXI)

Tabela 21: Estratégias argumentativas de porém (adversativo) dos séculos XX e XXI

Tabela 22: As funções semânticas dos juntivos distribuídas nos níveis de articulação

Tabela 23: As categorias sintáticas dos juntivos distribuídas nos níveis de articulação

Tabela 24: A relação adversativa para os diferentes itens na história da língua portuguesa

\section{LISTA DE GRÁFICOS}

Gráfico 1: A frequência token dos itens por século

p.

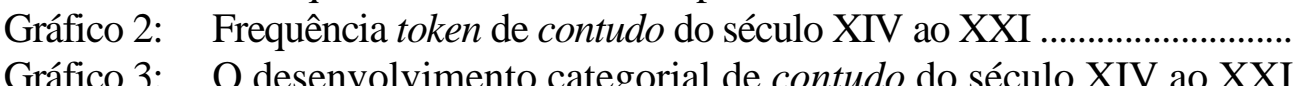

Gráfico 3: O desenvolvimento categorial de contudo do século XIV ao XXI

Gráfico 4: Os valores semânticos de contudo do século XIV ao XXI .....................

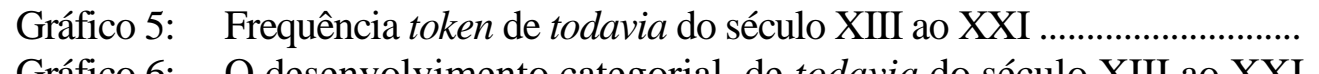

Gráfico 6: O desenvolvimento categorial de todavia do século XIII ao XXI XXI

Gráfico 10: Os valores semânticos de entretanto dos séculos XVI ao XXI ....

Gráfico 11: Frequência token de no entanto do século XIII ao XXI .................

Gráfico 12: O desenvolvimento categorial de no entanto do século XIII ao XXI

Gráfico 13: Os valores semânticos de no entanto dos séculos XIII ao XXI ....

Gráfico 14: Frequência token de porém do século XIII ao XXI ......................

Gráfico 15: O desenvolvimento categorial de porém do século XVI ao XXI

Gráfico 16: Os valores semânticos de porém do século XIII ao XXI ...............

Gráfico 17: A trajetória dos itens investigados na história da língua portuguesa 


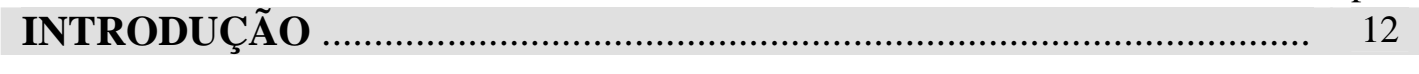

1. FUNDAMENTAÇÃO TEÓRICA …................................................ 19

1.1. Os precursores da gramaticalização .................................................................... 19

1.2. A Gramaticalização ......................................................................................... 23

1.2.1. A distinção entre unidade lexical e unidade gramatical ................................... 23

1.2.2. Gramaticalização: definição ..................................................................... 26

1.2.3. Perspectiva da gramaticalização: sincronia, diacronia ou pancronia ................. 29

1.2.4. O caminho da gramaticalização ...................................................................... $\quad 30$

1.2.5. Mecanismos de mudança da gramaticalização .................................................... 33

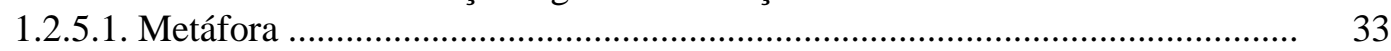

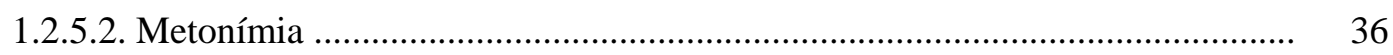

$\begin{array}{ll}\text { 1.2.5.3. Reanálise } & 38\end{array}$

1.2.5.4. Analogia ............................................................................................ 39

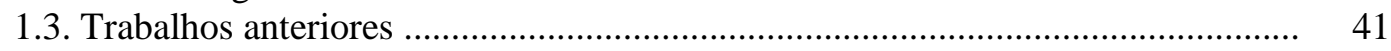

\section{ASPECTOS SINTÁTICO-SEMÂNTICOS DAS CONJUNÇÕES 46 ADVERSATIVAS}

2.1. O estatuto das conjunções adversativas em português ......................................... 46

2.2. Articulação de orações: coordenação ...................................................................... 49

2.3. A mudança semântica das conjunções ................................................................. 54

2.3.1. Eve Sweetser ........................................................................................... 54

2.3.2. Elizabeth Traugott $(1982,1999)$ e E. Traugott \& E. König (1991) - a mudança semântica em gramaticalização ................................................................. 56

\section{PROCEDIMENTOS METODOLÓGICOS ..................................... 61}

3.1. Composição dos corpora ................................................................................. 61

3.2. Apuração de frequência e análise dos dados ....................................................... 63

3.3. Por uma definição dos juntivos mais gramaticalizados ....................................... 66

\section{A GRAMATICALIZAÇÃO DOS ADVÉRBIOS JUNTIVOS ADVERSATIVOS PORÉM, CONTUDO, TODAVIA, ENTRETANTO E NO ENTANTO}

4.1. Apresentação geral 98

o

4.2. A gramaticalização dos advérbios juntivos adversativos .................................... 101

4.2.1 Contudo ................................................................................................... 101

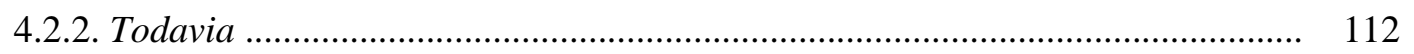

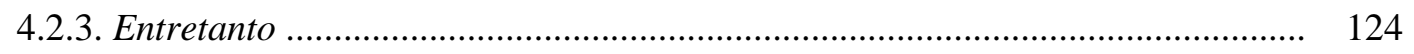

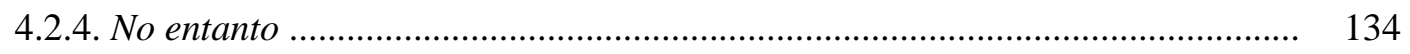

4.2.5. Porém …................................................................................................. 143

4.3. Grupo de fatores pouco relevantes na análise dos juntivos ................................. 155

4.4. Análise comparativa de porém, contudo, todavia, entretanto e no entanto .......... 159

CONSIDERAÇÔES FINAIS ...................................................................... 163

REFERÊNCIAS BIBLIOGRÁFICAS _........................................................... 167

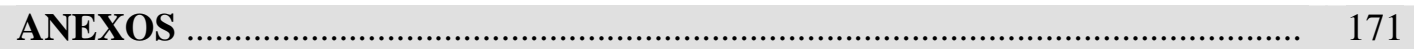




\section{INTRODUÇÃO}

Nesta pesquisa, investigamos, com base em diferentes sincronias da língua portuguesa, as mudanças sintáticas, semânticas e pragmáticas por que passaram os advérbios porém, contudo, todavia, entretanto e no entanto, conjuntamente, sob a perspectiva da gramaticalização, levando em consideração os elementos contextuais que contribuíram para que esses itens assumissem, em determinada sincronia, além do caráter juntivo, também um valor adversativo. Para apreendermos esses contextos, conjugamos as perspectivas sincrônica e diacrônica: por meio da investigação sincrônica, verificamos como os itens se comportam sintática e semanticamente e, pela diacronia, levantamos os contextos que explicam o desenvolvimento conjuncional e adversativo desses elementos. Recorre-se assim ao passado para explicar o presente.

A hipótese investigada é a de que os atuais usos juntivos desses itens são resultantes de um processo de gramaticalização na história do português, que envolve a passagem de advérbio > advérbio juntivo (> conjunção), trajetória que se assemelha à gramaticalização da conjunção adversativa mas, aqui usada como controle para checar o grau de gramaticalidade dos itens em análise.

Para o alcance do objetivo maior, percorremos os caminhos percorridos:

a) descrevemos em cada sincronia as mudanças sintáticas, semânticas e pragmáticas por que passam os itens;

b) analisamos a contribuição dos mecanismos atuantes na mudança via gramaticalização, a metáfora e a metonímia, tendo em vista a polêmica que se estabelece em torno de sancionar quais desses mecanismos prevalecem na mudança das conjunções adversativas; ${ }^{1}$

\footnotetext{
1 Confronte Said Ali (1964), Câmara (1975), Castilho (2004), para a defesa da atuação da metonímia, e Rocha (2006), para a da metáfora.
} 
c) analisamos os valores lógico-argumentativas dos usos adversativos dos itens (DUCROT, 1977 e 1981), relacionadas à distribuição de informação, a fim de depreendermos se, com o aumento da gramaticalização do item, há um aumento dos diferentes tipos de estratégias por ele atualizadas;

d) comparamos os diferentes funcionamentos de cada um dos itens ao o funcionamento da conjunção mas, por meio da possibilidade de paráfrase, com vistas a sancionar os usos que podem ser considerados mais gramaticalizados;

e) a partir dos resultados alcançados para cada item em cada uma das sincronias, propomos escalas que mostram: (i) a gramaticalidade dos diferentes usos de cada item; (ii) para cada um deles, a emergência do uso conjuncional e adversativo na história do português; (iii) entre eles, quais estão mais gramaticalizados e quais estão menos gramaticalizados.

Em seus estudos descritivos a respeito dos itens adversativos em questão, Neves (1998, 2000) observa que esses não se comportam como a conjunção adversativa prototípica mas, pois, diferentemente de mas, eles não têm uma posição fixa no início da segunda oração a que se ligam e podem co-ocorrer com outras conjunções, inclusive com o próprio mas. Segundo gramáticos históricos (SAID ALI, 1964; NUNES, 1975), esse comportamento diferenciado é resquício de origens adverbiais, o que, a nosso ver, parece ser uma justificativa forte o suficiente para não lhes atribuir o estatuto de conjunção prototípica. Neves (2000) prefere classificá-los como advérbios juntivos - advérbio, de valor anafórico, que equivaleria ao papel assumido por uma conjunção, como ilustram as ocorrências de 01 a 05, extraídas de Neves (2000, p.272-281).

(01) Punam-se os maridos que agridem as mulheres, fazendo-o, porém, com imediatismo.

(02) Sim, ele lhe falara no quanto era bela a morte $\boldsymbol{e}$ contudo continuava vivo, ele e Luciana vivos, sozinhos dentro de casa!

(03) Aqui o ódio continuava mais intenso ainda $\boldsymbol{e}$, todavia, foram obrigados a conviver na mesma senzala e como mercadoria de um mesmo proprietário.

(04) Aí está Minas: a mineiridade. Mas, entretanto, cuidado. 
(05) Dante é um homem da Idade Média e Petrarca é um homem do Renascimento $\boldsymbol{e}$, no entanto, são homens da mesma época.

Como se nota nas ocorrências de 1 a 5 , os itens adversativos apresentam uma certa mobilidade na sentença, podendo ocorrer no início, no meio ou no fim da segunda oração e, além disso, co-ocorrer com outras conjunções, inclusive, com a adversativa mas.

Said Ali, ao explicar o caráter fluido dos itens adversativos, afirma que:

como correlativos enfáticos é uma aplicação puramente ocasional dos ditos vocábulos. Resta a saber se fora deste caso servem de conjunção ou de advérbio. À tendência de incluí-los na categoria das partículas adversativas em atenção a terem sentido semelhante ao da palavra mas, objeta-se que a sinonímia é imperfeita e tanto que se usam, ou se podem usar, concomitantemente com esta partícula. Parece antes acharem-se na fronteira indecisa que medeia entre advérbio e conjunção (SAID ALI 1964, p.223).

O autor considera que os itens se encontram na fronteira entre advérbio e conjunção. Diante dessa constatação, consideramos que os itens porém, contudo, todavia, entretanto e no entanto estão em processo de gramaticalização, e, a partir de dados efetivos da língua em uso, podemos estabelecer diferentes estágios desse processo entre usos adverbiais e usos conjuncionais. Comparativamente, é preciso analisar quais itens estão mais avançados no processo de gramaticalização e tentar buscar as motivações dessa mudança.

Os estudos desenvolvidos sobre essa temática (MATTOS E SILVA, 1984; BARRETO, 1999; ROCHA, 2006; CASTILHO, 2004; LONGHIN-THOMAZI, 2006), concluem que porém, contudo, todavia, entretanto, no entanto se encontram ainda em processo de gramaticalização, pois, ao compará-los com a conjunção coordenativa adversativa prototípica mas, observa-se que eles apresentam características não tão bem delimitadas, ou seja, ao mesmo tempo, guardam resquícios das suas fontes adverbiais, como, mobilidade posicional e co-ocorrência com outros juntivos, e estabelecem a coordenação entre orações, propriedade essa dos itens conjuncionais. O caráter fluido desses itens advém do processo de mudança categorial advérbio > conjunção por que eles vêm passando. 
Levando em consideração as observações acima, pode-se considerar que os itens adversativos em questão colaboraram para a "reposição" do quadro conjuncional do português, pois, segundo gramáticos históricos (ALI, 1964; NUNES, 1975; CAMARA, 1975), na passagem do latim para o português, muitas conjunções foram abandonadas e, para compensar essa perda no sistema conjuncional, ocorreram vários processos de gramaticalização, em que palavras de diferentes categorias, em grande parte advérbios, passaram a funcionar como conjunções.

Quanto às conjunções adversativas, Nunes (1975) afirma que a língua portuguesa dispensou várias formas latinas, dando preferência ao item magis, que, desde o latim vulgar, já vinha sendo usado preferencialmente em detrimento de outras. Magis, no latim vulgar, era usado juntamente com a conjunção adversativa sed, dando ideia de "antes, preferência". Com o passar do tempo, magis assimilou, por meio de processo metonímico, o sentido adversativo de sed e passou a ser empregada sozinha, constituindo a conjunção adversativa prototípica mais da fase arcaica e mas da fase atual.

Além da partícula adversativa mais (mas), a língua recrutou, dentre itens pertencentes a outras categorias, principalmente a dos advérbios, itens que viriam a desempenhar uma função adversativa no enunciado, como é o caso de porém, todavia, entretanto, no entanto e contudo. O primeiro advém de um sintagma circunstancial latino constituído de preposição + elemento pronominal - per + inde - e tinha o sentido original de por isso; o segundo, por sua vez, origina-se do sintagma latino tota via, que significa em todo o caminho; os três últimos advêm de sintagmas preposicionados, sendo eles respectivamente: preposição entre + o pronome indefinido tanto; preposição in + pronome indefinido tantum; preposição cum + pronome indefinido totu, com os sentidos respectivos de "entre tantas coisas", "neste meio tempo" e "com todas as/essas coisas" (CUNHA, 1986). 
De acordo com Barreto (1999), os itens analisados adquiriram o sentido adversativo por um processo metonímico, “devido ao emprego do item em sentenças negativas ou em sentenças afirmativas precedidas por sentenças negativas” (p.259).

Para análise da argumentatividade dos itens selecionados, os trabalhos de Ducrot (1977, 1981) sobre argumentação na linguagem constituem fundamental contribuição. De acordo com o autor, a argumentatividade é algo que está inscrito na própria língua, isto é, a linguagem em qualquer instância é usada para fins argumentativos. Ao elaborar um enunciado, o locutor direciona o discurso para determinadas conclusões, excluindo outras. De modo geral, todo enunciado tem uma orientação argumentativa, que indica para quais conclusões esse enunciado pode servir de argumento.

Segundo Ducrot $(1977,1981)$, a língua dispõe de certos elementos que têm como função encadear os enunciados, determinando a sua orientação discursiva. Esses elementos recebem o nome de operadores argumentativos ou discursivos. Entre esses operadores argumentativos, encontram-se elementos que têm a função de marcar uma relação de contrajunção entre os enunciados, tais como, mas, porém, contudo, todavia, no entanto, entretanto, embora etc.

Dentre os itens que marcam essa relação de contrajunção, Ducrot (1977) faz uma análise do item mas (operador argumentativo por excelência), mostrando como esse item estabelece uma relação lógico-argumentativa entre dois enunciados $p$ e $q$. Nos moldes de Ducrot, os enunciados $p$ e $q$ são considerados argumentos para conclusões opostas: conclusão $r$ e não-r, respectivamente. Ducrot, para explicar essa relação entre o enunciado $p$ e $q$, utiliza a metáfora da balança, em que, de um lado, se tem o argumento $p$, considerado mais fraco, e, de outro, o argumento $q$, o mais forte. Como o falante dá maior importância para o enunciado q, a "balança" pende para a conclusão sugerida por esse enunciado (conclusão não-r), e por isso o sentido global do enunciado segue em acordo com a conclusão não-r. 
O diferencial desta pesquisa em relação aos demais trabalhos desenvolvidos sob a temática apresentada fica por conta de estar sendo proposta uma investigação da mudança sintática, semântica e pragmática de cada um dos itens, conjuntamente, isto é, analisar a trajetória de advérbio > conjunção, depreender os elementos que colaboraram para o surgimento da leitura de oposição dos itens e, além disso, discutir as questões pragmáticodiscursivas envolvidas nesse processo, observando, principalmente, as diferentes maneiras com que os itens são empregados para estabelecer relações lógico-argumentativas entre enunciados.

Para a demonstração dos resultados a que chegamos, o trabalho está dividido em quatro capítulos.

No primeiro capítulo, apresentamos o arcabouço teórico que sustenta nossa investigação. Para isso, num primeiro momento, enfocamos os precursores dos estudos em gramaticalização, para, num segundo momento, expormos algumas questões teóricas como a distinção entre unidade lexical e gramatical, o caráter não-dicotômico entre sincronia e diacronia, o princípio da unidirecionalidade e os mecanismos metáfora e metonímia, reanálise e analogia. No final desse capítulo, há uma sessão dedicada a trabalhos anteriores sobre a mesma temática que investigamos, com intuito de apontarmos os avanços do nosso trabalho, em relação a esses.

Dedicamos o segundo capítulo à apresentação dos aspectos sintáticos e semânticos dos itens adversativos. Abordamos, num primeiro momento, a discussão que há na literatura a respeito da inclusão dos itens adversativos investigados no rol das chamadas conjunções coordenativas, principalmente das conjunções adversativas. Discutimos também o modo de articulação das orações coordenadas. Na terceira seção desse capítulo, apresentamos os aspectos mais importantes dos trabalhos de Traugott (1982), Sweetser (1990), Traugott e 
König (1991) e Traugott (1999) sobre mudança semântica de conjunções, relevantes para a nossa investigação.

O terceiro capítulo trata dos aspectos metodológicos desta pesquisa, como a escolha dos corpora sincrônico e diacrônico e os critérios empregados na análise do processo de gramaticalização de cada um dos itens e no estabelecimento do cline de gramaticalidade entre eles.

No quarto capítulo, apresentamos os resultados da análise dos dados dos itens investigados, a partir dos fatores de análises discutidos no capítulo anterior. Numa primeira parte, expomos os resultados da análise de cada juntivo, depreendendo, assim, o processo de mudanças sintáticas, semânticas e pragmáticas de cada um deles. A segunda parte desse capítulo é dedicada à comparação dos itens, que resulta na escala de gramaticalidade entre eles.

Por fim, nas considerações finais, apresentamos os principais resultados da pesquisa. Fecham o trabalho as referências bibliográficas e os anexos, onde constam informações sobre os textos que compõem o corpus diacrônico. 


\section{CAPÍTULO I \\ FUNDAMENTAÇÃO TEÓRICA}

Neste capítulo, são expostos os pressupostos teóricos que guiam o trabalho. Num primeiro momento, nos reportamos aos precursores dos estudos em gramaticalização, para, depois, apresentarmos a distinção entre unidade lexical e unidade gramatical, a qual norteia as principais definições de gramaticalização; além disso, discorremos sobre a necessidade de um tratamento não dicotômico de sincronia e diacronia, sobre o princípio da unidirecionalidade e sobre os mecanismos que regem a gramaticalização - metáfora, metonímia, reanálise e analogia. No final desse capítulo, apresentamos outros trabalhos feitos sobre a mesma temática, a fim de apontarmos os avanços do nosso trabalho.

\subsection{Os precursores da gramaticalização}

Não são recentes os interesses na investigação das origens e do desenvolvimento de categorias gramaticais. Segundo Heine et al. (1991), os estudos que poderiam ser considerados precursores da gramaticalização datam do século $\mathrm{X}$, com os chineses, que reconheciam a diferença entre signos plenos e vazios, afirmando que esses se originam daqueles. Afirmação semelhante é feita no século XVIII pelos filósofos franceses, que apontavam que a complexidade gramatical e o lexema abstrato são derivados, historicamente, de lexemas concretos. No século XIX, Tooke apresenta a noção de "abreviação" ou "mutilação", que consiste no desenvolvimento de advérbios, preposições e conjunções (palavras secundárias) a partir da abreviação de nomes e verbos (palavras necessárias).

O gramático comparatista, Franz Bopp, também no século XIX, estuda, nas línguas européias, o desenvolvimento de auxiliares e flexões a partir de material lexical. Humboldt (1822 apud HOPPER \& TRAUGOTT, 1993, p. 18-19), na palestra intitulada On the genesis 
of grammatical forms and their influence on the development of ideas, afirmava que as estruturas gramaticais das línguas são precedidas de um estágio evolucionário em que só ideias concretas poderiam ser expressas. $\mathrm{O}$ autor propõe a existência de quatro estágios para entender como os significados atingem o estágio morfológico, mais gramatical, como mostrado no quadro 1 , abaixo.

\begin{tabular}{|c|l|}
\hline $\begin{array}{c}\text { Estágio I } \\
\text { (estágio pragmático) }\end{array}$ & $\begin{array}{l}\text { Somente coisas são denotadas, objetos concretos cujas relações não são } \\
\text { feitas de modo explícito no discurso, mas são inferidas pelo ouvinte. }\end{array}$ \\
\hline $\begin{array}{c}\text { Estágio II } \\
\text { (estágio sintático) }\end{array}$ & $\begin{array}{l}\text { A ordem em que os objetos são apresentados torna-se habitual e a ordem } \\
\text { fixa das palavras introduz o presente estágio; algumas palavras começam a } \\
\text { se especializar para funcionar de modo mais relacional no discurso. }\end{array}$ \\
\hline $\begin{array}{c}\text { Estágio III } \\
\text { (cliticização) }\end{array}$ & Nesse estágio, as palavras funcionais ligam-se às palavras materiais. \\
\hline $\begin{array}{c}\text { Estágio IV } \\
\text { (estágio } \\
\text { morfológico) }\end{array}$ & $\begin{array}{l}\text { Os pares aglutinativos se fundem, tornando-se uma única palavra complexa. } \\
\text { Além disso, nesse estágio, algumas palavras funcionais podem continuar } \\
\text { suas trajetórias como indicadores puramente formais de relações } \\
\text { gramaticais. }\end{array}$ \\
\hline
\end{tabular}

Quadro 01: Estágios de evolução da língua

Humboldt (1822, apud HOPPER \&TRAUGOTT, 1993, p. 18-19)

O neogramático alemão Georg von der Gabelentz (1891, apud HOPPER e TRAUGOTT, 1993, p. 20) estudou as origens e a evolução das formas gramaticais, que ao caírem gradativamente em desuso, são substituídas por novas formas. Ele sugere que esse processo de evolução seja o resultado de duas tendências em competição, uma em direção a facilidade da articulação e a outra em direção à distintividade. Segundo o autor, pronúncias relaxadas provocam mudanças que desgastam as palavras, tornando as distinções menos acentuadas. Então novas formas intervêm e assumem funções aproximadas das antigas palavras. Gabelentz aborda também a noção de espiral evolucionária para a explicação do desenvolvimento de categorias gramaticais. Segundo o autor, o processo de recrutamento de formas gramaticais é recorrente, e as condições para esse desenvolvimento espiralado estão sempre presentes nas línguas. 
A ideia de evolução, vista tanto em Humboldt (1822) como em Gabelentz (1891), é muito criticada pelos estudiosos da gramaticalização, pois ficaria subentendido que os estágios iniciais são menos complexos que os mais avançados. Não é demais recordar que essas eram as primeiras ideias sobre mudança e, portanto, não parece adequado afirmar que, de fato, imperasse a crença da existência de estágios mais e menos evoluídos da língua.

Embora as noções fundantes da gramaticalização já se encontrassem nos trabalhos dos autores supracitados, foi Antoine Meillet, em seu artigo L'evolution des formes grammaticales (1948 [1912]), que reconheceu a importância desse processo de mudança linguística e que cunhou o termo gramaticalização tal como é basicamente ainda hoje empregado. Diferentemente da primeira geração dos indo-europeístas, Meillet mostra que a discussão tem de sair do campo da origem das formas gramaticais e ir para o campo de suas transformações. Em seu artigo, Meillet descreve dois processos pelo qual emergem novas formas gramaticais. Um deles é a analogia, que consiste na emergência de novas formas a partir de um paradigma já existente. O outro é a gramaticalização, que se refere à "atribuição de um caráter gramatical a uma palavra anteriormente autônoma". ${ }^{1}$ Essa atribuição se desenvolve por meio de uma espécie de continuum, e, nos casos em que se pode conhecer a origem da palavra gramatical, a fonte era uma palavra lexical. Enquanto a analogia afeta o eixo paradigmático, a gramaticalização opera no eixo sintagmático, ou criando formas novas ou introduzindo categorias gramaticais sem expressão linguística. Sendo assim, a gramaticalização muda o sistema linguístico como um todo. Nas palavras de Meillet:

Enquanto a analogia pode renovar os detalhes das formas, deixando intacto o plano geral do sistema existente, a gramaticalização de certas palavras cria novas formas, introduz categorias que não tinham expressão, e transforma o sistema como um todo. ${ }^{2}$

(MEILLET, 1948 [1912], p. 133)

\footnotetext{
1 "l'attribution du caractere grammatical à un mot jadis autonome" (Meillet, 1948 [1912], p. 131). Essa e as demais versões para o português de textos em língua estrangeira são de nossa responsabilidade.

2 "Tandis que l'analogie peut renouveler le détail des formes, mais laisse lê plus souvent intact le plan d'ensemble du système existent, la <<grammaticalisation>> de certains mots crées des formes neuves, introduit des categories qui n'avaient pas d'expression linguistique, transforme l'ensemble du système.
} 
Segundo o autor, a gramaticalização ocorre devido à necessidade dos falantes de serem expressivos, buscando um modo inovador na linguagem de dizer ideias já conhecidas. Em relação às conjunções, Meillet afirma que essas tendem a enfraquecer pelo uso frequente e velocidade com que são pronunciadas, o que acaba favorecendo o desgaste de material semântico e a perda de expressidade, necessitando, então, a renovação das formas. Os falantes, por sua vez, inconscientemente, reagem à automatização, criando formas alternativas a partir do repertório existente na língua. Lehmann (2002 [1982], p.4) considera que o desgaste e a expressividade, tratados por Meillet, correspondem aos fatores facilidade e distintividade, de Gabelentz (1891).

Para Meillet, a gramaticalização não tem um fim, ou seja, constantemente a necessidade de expressividade faz com que se criem palavras surpreendentes que, em um determinado estágio, vão se desgastar, passando a ser utilizadas apenas como acessórios gramaticais. Como diz Meillet,

as línguas seguem ainda um período de desenvolvimento em espiral: elas empregam palavras acessórias para obter uma expressão intensa, estas palavras se enfraquecem, se degradam e caem ao nível de ferramentas gramaticais simples, o usuário da língua emprega novas palavras ou palavras diferentes no ponto de vista da expressão, o enfraquecimento recomeça, e assim sucessivamente ${ }^{3}$.

(MEILLET, 1948 [1912], p. 140-141)

No final do seu artigo, Meillet, ao se referir à fixação da ordem de palavras na passagem do latim às línguas românicas, dá alguns indícios de que a gramaticalização poderia ser tratada para além do nível do léxico, atingindo também o nível da oração. No latim, os constituintes das frases não seguiam uma ordem canônica, em razão de serem marcados pela morfologia de casos. Na passagem para as línguas românicas, a marcação de casos deixa de

\footnotetext{
${ }^{3}$ les langues suivent ainsi une soire de développement em spirale: eles ajoutent des mots accessoires pour obtenir une expression intense; ces mots s'affaiblissent, se degradent et tombent au niveau de simples outils grammaticaux; on ajoute de nouveaux mots ou des mots différents em vue de l'expression, l'affaiblissement recommence, et ainsi sans fin.
} 
ser empregada, e a ordem de palavras na frase passa a assumir valor gramatical, ou seja, a ser uma instanciação de caso. Por essa mudança, podem-se notar dois fatos a respeito do processo de gramaticalização: (i) envolve mudança de significado gramatical; (ii) cria novos meios gramaticais para designar ideias já existentes. Por meio desse exemplo, observa-se que não há fronteiras no percurso da gramaticalização, podendo ser aplicado tanto ao nível da palavra quanto ao nível da oração.

Segundo Hopper e Traugott (2003), após os trabalhos de Meillet, a linguística foi dominada pelos estudos estruturalistas de base saussureana, fazendo com que a gramaticalização fosse vista com estudos de linguística histórica. Com base no estruturalismo, a descrição linguística é feita sincronicamente, com isso, são descartados aspectos da mudança linguística, principalmente de base diacrônica. Durante esse período, os estudos mais significativos que abordam aspectos da mudança linguística foram de Kurylowicz (1965), de Watkins (1965) e de Benveniste (1965). A gramaticalização voltou a ser discutida na década de 1970, em que havia questionamentos sobre o caráter estático da descrição linguística e começou também um interesse pela pragmática.

\subsection{A Gramaticalização}

\subsubsection{A distinção entre unidade lexical e unidade gramatical}

Segundo Hopper e Traugott (1993, p.4), os linguistas que estudam a gramaticalização trabalham com a distinção entre palavras de conteúdo, também chamadas lexicais, e palavras funcionais, também gramaticais. Categorias como nomes, verbos e adjetivos pertencem à classe dos itens lexicais e servem para descrever coisas, ações e qualidades. Por outro lado, preposições, conjunções, pronomes e demonstrativos pertencem à classe das palavras gramaticais e servem para indicar relações entre nomes, para ligar partes de um discurso, para indicar se as entidades e participantes de um discurso já são ou não identificadas e para 
mostrar se eles estão próximos do falante ou do ouvinte. Em suma, os autores propõem agrupar as palavras em três categorias, a saber: categoria maior, à qual pertencem nomes e verbos plenos, categoria medial, que agrupa adjetivos e advérbios, e categoria menor, à qual se integram preposições, conjunções, auxiliares, demonstrativos etc. Esse modo de divisão do léxico pressupõe uma disposição das categorias numa escala de gramaticalidade que refletiria uma trajetória de gramaticalização entre elas, que teria o seguinte formato: categoria maior > categoria medial > categoria menor. Embora os autores não mencionem claramente, é possível que dentro de uma dada categoria as classes de palavras possam também comportar um arranjo interno de gramaticalidade que, por exemplo, permita reconhecer que uma preposição é mais gramatical (ou gramaticalizada) do que um verbo auxiliar.

Meillet (1948 [1912]) já fazia a distinção de três classes de palavras, as principais (nomes, adjetivos, verbos e complementos circunstanciais), as acessórias e as gramaticais (preposições, conjunções e auxiliares), concebendo que as acessórias e as gramaticais se desenvolvem, diacronicamente, das principais, o que permite associar as principais com os itens lexicais e as acessórias e gramaticais com as palavras gramaticais.

Na distinção entre as propriedades de "ser lexical" e de "ser gramatical", Heine et al. (1991) propõem a noção de conceito fonte, relativamente à categoria alvo de um processo de gramaticalização. Eles apresentam um conjunto de critérios para distinguir conceitos lexicais de gramaticais, os quais seguem ilustrados no quadro 2, à página seguinte. 


\begin{tabular}{|c|c|}
\hline CONCEITOS LEXICAIS & CONCEITOS GRAMATICAIS \\
\hline $\begin{array}{l}\text { - são menos "abstratos"; incluem os } \\
\text { conceitos concretos, tais como objetos, } \\
\text { ações e qualidades. }\end{array}$ & - são mais "abstratos". \\
\hline • são autossemânticos. & - são sinsemânticos. \\
\hline $\begin{array}{l}\text { - } \begin{array}{l}\text { contribuem para o conteúdo da } \\
\text { representação } \\
\text { referencial). }\end{array} \text { cognitiva (função } \\
\end{array}$ & $\begin{array}{l}\text { - tendem a determinar a estrutura da } \\
\text { representação cognitiva (cf. Talmy, 1988). }\end{array}$ \\
\hline - possuem mais material fonológico. & - possuem menos material fonológico. \\
\hline $\begin{array}{l}\text { - são de uso geral e menos frequentes e, por } \\
\text { isso menos previsíveis no discurso. }\end{array}$ & $\begin{array}{l}\text { - são de uso mais frequente e, por isso, mais } \\
\text { previsíveis no discurso. }\end{array}$ \\
\hline - integram classe aberta. & - integram classes fechadas. \\
\hline - são codificados por lexemas. & $\begin{array}{l}\text { - tendem a ser codificados por auxiliares, } \\
\text { partículas, clíticos, afixos, unidades supra- } \\
\text { segmentais, distinções na ordem de } \\
\text { palavras etc. }\end{array}$ \\
\hline
\end{tabular}

Quadro 02: Conceitos lexicais e conceitos gramaticais (Heine et al., 1991)

Os estudiosos da gramaticalização constatam algumas observações interessantes a respeito dos itens lexicais que são candidatos a gramaticalização. Heine et al. (1991) observam que esses termos são culturalmente mais independentes, isto é, são universais da experiência humana. Além disso, eles representam aspectos básicos e concretos da relação humana com o ambiente, com ênfase ao meio espacial, incluindo partes do corpo humano. Como exemplo, têm-se os verbos come e go, em construções de futuro; back (costas), objeto do corpo humano, concreto, que serve de conceito-fonte para um conceito espacial, como em three miles back. No português, temos casos semelhantes, como o verbo ir, usado em construções de futuro, e também as expressões à face de, em face de, de face, que denotam conceitos espaciais, uma posição relativa a outra.

Essas distinções entre conceitos lexicais e conceitos gramaticais, de caráter mais didático do que funcional, tomam por base a prototipia dos itens que integram cada uma dessas classes, uma vez que não há como traçar com nitidez os limites entre as palavras lexicais e as palavras gramaticais, fato reconhecido pelos próprios autores referenciados 
(HOPPER \& TRAUGOTT, 1993; HEINE et al., 1991). O próprio processo de gramaticalização mostra que não há pontos discretos entre o léxico e gramática, mas, sim, uma espécie de continuum, em que a transição do lexical para o gramatical ou do menos gramatical para o mais gramatical é gradual.

\subsubsection{Gramaticalização: definição}

Na literatura sobre gramaticalização, não há um consenso sobre a definição do processo de gramaticalização. A definição dada por Meillet contempla a passagem do lexical para o gramatical e dentro do gramatical há a passagem do sintático para o morfológico, conforme esquema abaixo, extraído de Gonçalves (2003).

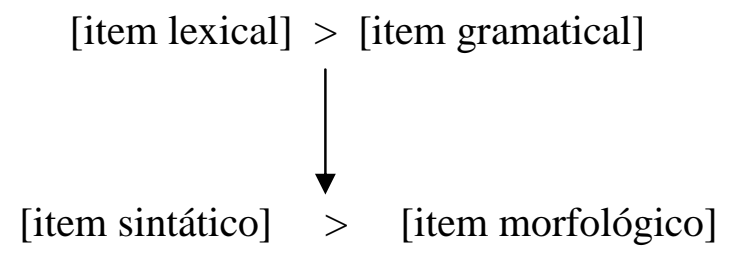

Kurylowicz (1965, p.52, apud LEHMANN, 2002[1982], p.6) define o processo como "o aumento do uso de um morfema, que avança de um status lexical para um status gramatical ou de um menos gramatical para um mais gramatical, por exemplo, de um formante derivacional para um formante flexional ${ }^{4,}$.

Givón (1979), baseado na proposta de Hodge (1970, apud LEHMANN, 2002 [1982], p.7), distingue dois estágios intervenientes na gramaticalização: o primeiro refere-se a uma sintaxe forte e uma morfologia fraca, enquanto o segundo, a uma sintaxe fraca e uma morfologia forte. Segundo ele, a gramaticalização aconteceria do discurso em direção à morfossintaxe. Num primeiro momento, o autor apresenta o slogan "a morfologia de hoje é a sintaxe de ontem", ampliando-o, posteriormente, para considerar que "a sintaxe de hoje é a

\footnotetext{
${ }^{4}$ the increase of the range of a morpheme advancing from a lexical to a grammatical or from a less grammatical to a more grammatical status, e.g. from a derivative formant to an inflectional one.
} 
pragmática discursiva de ontem”. Esse último slogan foi apropriado pela linguística funcionalista como uma forma de se contrapor ao formalismo vigente. $\mathrm{O}$ autor propõe a seguinte escala de mudança: Discurso $>$ Sintaxe $>$ Morfologia $>$ Morfofonêmica $>$ Zero

Givón também apresenta a tese de que as estruturas discursivo-pragmáticas, tipicamente mais "frouxas", se desenvolvem, ao longo do tempo, em estruturas sintáticas gramaticalizadas, tipicamente mais “ajustadas". Esse desenvolvimento se dá via sintaticização, ${ }^{5}$ em que as formas do discurso são vistas em clines e variantes entre os pólos pragmático e sintático.

\begin{tabular}{|c|c||}
\hline Pólo pragmático, “frouxo" & Pólo sintático, “ajustado" \\
\hline Pidgin & Crioulo \\
\hline Linguagem Infantil & Linguagem adulta \\
\hline Linguagem informal & Linguagem formal \\
\hline Discurso oral, não-planejado & Discurso escrito, planejado \\
\hline
\end{tabular}

Quadro 03: Classificação das formas de discurso (GONÇALVES et al., 2007)

Os estudos givonianos tiveram um importante papel nos estudos da gramaticalização pela ênfase dada ao componente discursivo. Com isso, os estudos deixaram de ter o foco na passagem do lexical para o gramatical e começaram a se ater na passagem do discursivo para o gramatical.

Hopper e Traugott (2003 [1993]), por sua vez, afirmam que a gramaticalização é um processo pelo qual itens e construções lexicais passam, em determinados contextos, a assumir funções gramaticais, e, uma vez gramaticalizados, continuam a desenvolver novas funções gramaticais. Os autores sugerem o seguinte cline de mudança, que enfatiza o caráter categorial do léxico: [item de conteúdo] > [palavra gramatical] > [clítico] > [afixo flexional]. Valendo-se dessa definição, podemos pensar sobre o caso dos itens investigados,

\footnotetext{
${ }^{5}$ Givón prefere o termo sintaticização a gramaticalização.
} 
uma vez que eram itens lexicais que funcionavam como advérbio e passam em determinados contextos, que serão investigados no capítulo IV, a desempenhar papel de conjunção que seriam mais gramaticais que os advérbios.

Traugott e König (1991) referem-se à gramaticalização como um processo dinâmico, unidirecional e histórico, por meio do qual itens lexicais, no curso do tempo, adquirem um estatuto novo como o de formas gramaticais, morfossintáticas.

Bybee (2002) define gramaticalização como o processo pelo qual "um item lexical torna-se um morfema gramatical dentro de construções particulares ${ }^{6}$. Bybee, assim como Traugott, em seus trabalhos mais recentes, acredita que a gramaticalização está atrelada à criação de novas construções. Para a autora, a gramática não é estática, fechada, nem tem um conteúdo próprio, mas, sim, está suscetível à mudança e é altamente afetada pelo uso linguístico. A autora apresenta algumas características do processo de gramaticalização, quais sejam:

i. palavras e sintagmas que sofrem gramaticalização são reduzidos foneticamente, por meio de assimilações e eliminações de consoantes e vogais, produzindo sequências que exigem menos esforço muscular.

ii. significados concretos que entram no processo tornam-se generalizados e mais abstratos e, como resultado, tornam-se apropriados a uma crescente gama de contextos.

iii. a frequência de uso das construções gramaticalizadas aumenta radicalmente conforme a gramaticalização se desenvolve, fazendo crescer também os tipos de contexto em que as novas construções são possíveis.

iv. as mudanças na gramaticalização ocorrem muito gradualmente e são acompanhadas por muitas variações na forma e na função.

\footnotetext{
${ }^{6}$ a lexical item becomes a grammatical morpheme within a particular construction.
} 
Segundo Bybee (2002), o desenvolvimento de construções gramaticais está relacionado à linguagem em uso, uma vez que os significados e as funções das construções não são fixos e categóricos, permitindo a variação, que acaba levando a uma mudança gradual no tempo. As construções gramaticais são consideradas unidades automatizadas e convencionalizadas e, devido à alta frequência de repetições dos itens lexicais, seus significados sofrem mudança, via os processos de generalização e inferência pragmática. Quanto às implicações da gramaticalização, Bybee classifica os universais de mudança como universais cognitivos e comunicativos, sendo eles:

i. habilidade para automatizar sequência neuromotoras por meio da repetição;

ii. habilidade para categorizar elementos linguísticos recorrentes;

iii. tendência em inferir mais do que é dito;

iv. tendência a habitualizar estímulos repetidos.

Como se nota, essas definições se completam e podem ser consideradas variantes aprimoradas da definição clássica dada por Meillet (1948 [1912]). Gonçalves et al. (2007, p. 27) resumem as definições apresentadas acima na seguinte escala evolutiva dos estudos da gramaticalização:

(i) Meillet: lexical > gramatical

(ii) Kurylowicz: [-gramatical] $>$ [+gramatical]

(iii) Versões atuais: [qualquer material linguístico] > [+gramatical]

\subsubsection{Perspectiva da gramaticalização: sincronia, diacronia ou pancronia}

Segundo Heine (1991, p.10-11), até 1970, a gramaticalização foi vista como parte da linguística histórica, disciplina dentro da qual se estudava a evolução linguística, reconstruindo a história de uma determinada língua ou grupos de línguas. Após 1970, os 
estudos sobre gramaticalização passaram a ser considerados também como meios para explicar a gramática sincrônica.

Hopper \& Traugott (1993, p.2) apresentam duas perspectivas de estudo de gramaticalização: a dimensão sincrônica, sob a qual se estuda o fenômeno do ponto de vista dos padrões fluidos de uso linguístico; e a histórica ou diacrônica, que permite abordar as origens das formas gramaticais e as mudanças típicas que as afetam. Os autores, no entanto, admitem também a conjugação dessas duas perspectivas, numa chamada perspectiva pancrônica.

Heine et al. (1991) defendem a ideia de que não há uma separação nítida entre sincronia e diacronia, uma vez que uma não pode ser entendida independentemente da outra. Esses autores, juntamente com Hopper \& Traugott (2003 [1993], defendem uma posição pancrônica nos estudos da gramaticalização. Essa visão, segundo Burridge (1993 apud NEVES, 1997), se dá a partir de relação de interdependência entre o sistema linguístico e o uso, e entre os padrões fluidos da gramática e a importância do estudo diacrônico para a compreensão da gramática sincrônica.

Sendo assim, a teoria da gramaticalização juntamente com os estudos recentes da linguística não admite a rigidez da dicotomia saussureana, podendo a gramaticalização ser abordada a partir da conjunção das duas perspectivas, como será feito neste trabalho.

\subsubsection{O caminho da gramaticalização: a unidirecionalidade}

$\mathrm{Na}$ maioria das definições clássicas de gramaticalização, os autores partem do pressuposto de que o processo se dá num caminho unidirecional, ou seja, sempre do lexical para o gramatical ou do menos gramatical para o mais gramatical, e não ao contrário. Antes de apresentar a importância da unidirecionalidade nos estudos da gramaticalização, é necessário expor a noção de cline oferecida por alguns autores. 
Hopper \& Traugott (1993, p.6) afirmam que, do ponto de vista da mudança, as formas não mudam abruptamente de uma categoria para outra, mas, sim, passam por uma série de transições graduais, acompanhadas de variação na forma e na função. Para tanto, lançam mão da noção de cline, que tem implicações históricas e sincrônicas. Sincronicamente, o cline seria uma linha imaginária em que, de um lado, estariam os itens lexicais e, de outro lado, os itens gramaticais. De uma perspectiva histórica, o cline representa a trajetória de desenvolvimento de um item.

Os autores afirmam que não se deve concluir a partir da disposição do cline que tudo está em sequência, pois, como se sabe, há estágios de sobreposição entre seus pontos focais, ou seja, entre forma antiga e nova ou entre as funções desempenhadas pela forma. Para mostrar a não-linearidade do cline, Heine et al. (1991b) preferem usar o termo chaining (cadeia).

A unidirecionalidade é vista como uma característica básica do processo de gramaticalização, em que os itens migram de uma categoria para outra seguindo uma trajetória específica, que não pode ser revertida.

Hopper \& Traugott (1993), ao definir unidirecionalidade, mostram a importância do contexto na trajetória de mudança e afirmam que a passagem do lexical para o gramatical não é direta. Essa passagem segue a trajetória: item lexical usado em contextos específicos > sintaxe > morfologia. Os itens lexicais que se tornam gramaticalizados devem, primeiramente, servir a funções discursivas, tornando-se sintaticamente fixos para, depois, virem a se constituir um morfema.

A postulação básica é a de "que há uma relação entre dois estágios $A$ e $B$, tal que $A$ ocorre antes de $B$, mas não vice e versa. Isso é o que se entende por unidirecionalidade"7 (HOPPER \& TRAUGOTT, 1993, p.95). A esse respeito, Meillet (1948 [1912]) já falava de

\footnotetext{
${ }^{7}$ that there is a relationship between two stages A e B, such that A occurs before B, but not vice versa. This is what is meant by unidirecionality.
} 
um curso previsível que norteia a gramaticalização. Segundo o autor, as palavras principais (nomes, adjetivos, verbos e advérbios) da língua servem como fonte das palavras acessórias e gramaticais (auxiliares, preposições, conjunções, etc), e não o inverso.

Segundo Gonçalves et al. (2007), os teóricos que defendem a hipótese da unidirecionalidade já a assumem previamente, uma vez que ela é definitória do próprio processo de gramaticalização, o qual invariavelmente pressupõe aumento de gramaticalidade, e ao mesmo tempo é propriedade dos mecanismos que regem o processo: sintaticização (menos fixo > mais fixo), morfologização (item lexical > morfema), generalização de significados (concreto > abstrato), erosão fonética (mais material fonológico > menos material fonológico).

Hopper \& Traugott (1993) afirmam que

a hipótese da unidirecionalidade é forte. Há evidências de um grande número de exemplos de surgimento de estruturas gramaticais que envolveram o desenvolvimento de itens ou sintagmas lexicais ou, por meio do uso discursivo, de sintagmas lexicais em itens gramaticais, e desse para um item mais gramatical. Outro fator notado é que essas mudanças são acompanhadas pela descategorização de uma categoria maior para uma menor. ${ }^{8}$

(HOPPER \& TRAUGOTT, 1993, p. 128)

Os autores afirmam que não há nada de determinístico sobre a gramaticalização e a unidirecionalidade, uma vez que as mudanças podem não ocorrer. A mudança de um item pode não se completar, ou seja, ela não precisa atingir o final do cline ou passar por todos os estágios de um cline.

Na consideração da unidirecionalidade em gramaticalização, contra-exemplos com base em uma trajetória do tipo mais gramatical > menos gramatical são tão raros e obscuros que não chegam a constituir contra-evidência forte o suficiente para desbancar esse princípio

\footnotetext{
${ }^{8}$ the unidirecionality is a strong hypothesis. The evidence is overwhelming that a vast number of known instances of the development of grammatical structures involved the development of a lexical item or phrase through discourse use into a grammatical item, and then into an even more grammatical item, and that these changes were accompanied by decategorialization from a major to a minor category.
} 
fundamental. Casos identificados como de poligramaticalização são por vezes inapropriadamente apontados como contra-exemplo da trajetória da unidirecionalidade. Por poligramaticalização, entende-se os múltiplos caminhos que uma mesma forma pode seguir e não a reversibilidade do processo, como ilustra o estudo de Craig (1991) sobre os diferentes caminhos percorridos por *bang "ir", em Rama, do qual resultam : (i) um morfema de tempo; (ii) uma adposição de finalidade em nomes; (iii) uma conjunção. Todos esses são de caráter mais gramatical do que o verbo do qual originam.

\subsubsection{Mecanismos de mudança da gramaticalização}

Nesta subseção, serão expostos os principais mecanismos cognitivos envolvidos nos processos de gramaticalização, a metáfora e a metonímia, a fim de, no capítulo IV, mostrarmos a contribuição desses dois mecanismos para o processo de gramaticalização dos adversativos.

A metáfora, de modo geral, é o mecanismo por meio do qual itens abstratos são entendidos a partir de itens concretos, a metonímia, conhecida também como reinterpretação induzida pelo contexto, refere-se à mudança que uma determinada forma sofre devido ao contexto em que está sendo utilizada.

Hopper \& Traugott (1993, p.32) reconhecem também a importância da reanálise e da analogia para mudança em geral, principalmente para mudança morfossintática.

\subsubsection{Metáfora}

Os processos metafóricos podem ser definidos como processos de transferência de sentidos por meio de fronteiras conceituais. Essa transferência envolve uma abstratização de significados, uma vez que itens de um domínio mais concreto são utilizados para se referir a 
itens de um domínio mais abstrato. Nesse processo, é identificado o bleaching semântico da forma fonte de um processo de gramaticalização.

O processo metafórico tem sido visto por muitos autores (SWEETSER, 1990; HEINE et al., 1991; LICHTENBERK, 1991 apud BYBEE, 1994) como o principal mecanismo de mudança em gramaticalização.

Heine et al. (1991) afirmam:

Nós tentaremos demonstrar que a transferência metafórica é uma das principais forças condutoras do desenvolvimento de categorias gramaticais, isto é, para expressar funções mais abstratas, entidades concretas são recrutadas. ${ }^{9}$

(HEINE et al., 1991, p. 48)

$\mathrm{Na}$ literatura sobre gramaticalização, muitos trabalhos relacionam os processos metafóricos com a mudança semântica, no entanto alguns autores, entre eles Hopper \& Traugott (1993), argumentam que os processos metafóricos, por serem baseados na comunicação, estão relacionados à pragmática.

Heine et al. (1991) propõem uma escala na qual se dispõem algumas categorias cognitivas básicas num crescente de abstratização. Essa disposição revela como a cognição humana opera metaforicamente com tais categorias: pessoa > objeto > processo > espaço > tempo > qualidade.

Segundo os autores, cada uma dessas categorias representa um domínio de conceituação relevante para a estruturação da experiência humana e, assim, uma categoria mais à direita pode ser conceitualizada a partir de uma mais à esquerda. Com base nessa escala, surge a noção de metáfora categorial, por meio da qual, por exemplo, a noção de tempo pode ser estruturada a partir da noção de espaço.

\footnotetext{
${ }^{9}$ We try to demonstrate that metaphorical transfer forms one of the main driving forces in the development of grammatical categories; that is, in order to express more "abstract" functions, concrete entities are recruited.
} 
Neves (1997), para explicar essa escala de abstratização, mostra alguns exemplos do português, como: o nome pé (pé da Maria), que se refere a uma parte do corpo, é utilizado para designar uma parte de um objeto (pé da mesa); ou perto, que indica uma posição no espaço (perto da minha casa), passa a designar uma posição no tempo (perto do Natal).

Heine et al. (1991) apresentam um tipo de correlação entre essas categorias metafóricas, a divisão de classes de palavras e os tipos de constituintes, como ilustrado no quadro 04.

\begin{tabular}{||lll||}
\hline Categoria & Tipo de Palavra & Tipo de Constituinte \\
PESSOA & Nome humano & Sintagma nominal \\
OBJETO & Nome concreto & Sintagma nominal \\
ATIVIDADE & Verbo dinâmico & Sintagma verbal \\
ESPAÇO & Advérbio, adposição & Sintagma adverbial \\
TEMPO & Advérbio, adposição & Sintagma adverbial \\
QUALIDADE & Adjetivo, verbo & Modificador \\
& de estado, advérbio & \\
\hline
\end{tabular}

Quadro 04: Correlação entre categorias metafóricas, classes de palavras e tipos de constituintes

(HEINE et al., 1991, p.53-54)

Heine et al (1991, p.48) reconhecem que a transferência metafórica acarreta uma mudança abrupta de um domínio para o outro, enquanto a gramaticalização sugere uma mudança gradual. A metáfora e a metonímia não só são compatíveis uma com a outra, mas também formam aspectos complementares que estão necessariamente presentes no processo de gramaticalização. Dessa forma, a metáfora é interpretada como uma estratégia cognitiva que nos auxilia no entendimento da gramaticalização, porém não explica a gramaticalização ou o comportamento gramatical. 


\subsubsection{Metonímia}

A metonímia ocorre quando um item, em determinado contexto, adquire um sentido adicionado ao seu sentido original, e este segundo sentido torna-se gradualmente convencionalizado ao sentido do item.

Heine et al. (1991, p.61) definem a metonímia como "uma figura de linguagem por meio da qual o nome de uma entidade é usado para outra entidade de algum modo contígua à primeira". 10

Traugott e König (1991, p.70) argumentam que a metonímia serve ao mecanismo de fortalecimento de informatividade. De acordo com autores, a mudança semântica desse tipo contrasta com a metáfora, que está associada à solução de um problema de representação. A metonímia, por sua vez, está associada a resolução de um problema de informatividade e de relevância na comunicação.

Segundo Heine et al. (1991, p.71), o surgimento da metonímia deve-se à manipulação discursivo-pragmática dos conceitos que estão sujeitos a fatores contextuais na interpretação. A esse processo, os autores dão o nome de reintepretação induzida pelo contexto. No processo de gramaticalização, os autores afirmam que há a coexistência do processo metonímico e metafórico, que tem a seguinte estrutura:

$$
\mathrm{A} \Rightarrow \mathrm{A}, \mathrm{B} \Rightarrow \mathrm{B}
$$

(HEINE et al.,1991, p.74)

Essa coexistência do processo metafórico e metonímico pode ser vista no desenvolvimento de algumas conjunções, como o since do inglês, conforme Traugott e König (1991). Essa conjunção, que originalmente tem um sentido temporal, passa a assumir, em

\footnotetext{
${ }^{10}$ a figure of speech whereby the name of an entity is used to refer to another entity that is contiguous in some way to the former entity.
} 
determinados contextos, uma noção causal, até adquirir um sentido puramente causal, como mostrado nos exemplos de 06 a 08 fornecidos pelos autores.

(06) I have done quite a bit of writing since we last met. (temporal)

(07) Since Susan left him, John has been very miserable. (temporal/causal)

(08) Since you are not coming with me, I will have to go alone. (causal)

Como se vê, em (6), since estabelece o marco temporal para a execução da atividade feita pelo locutor, na ocorrência (7), a conjunção since pode ser interpretada como temporal ou como causal. Como temporal, temos que John se torna miserável, no momento em que Susan o deixa, já, como causal, temos que Susan deixar John é a causa para ele se tornar miserável. Por fim, em (8), since apresenta a causa para o locutor ter de ir sozinho.

A passagem do domínio tempo para o domínio causa é representante de um processo metafórico, enquanto o estágio intermediário, em que, a partir de um determinado contexto, o sentido causal emerge, é representante de um processo metonímico. Essa mudança de since pode ser representada pelo seguinte cline: tempo $>$ tempo/causa $>$ causa.

Tanto a metáfora quanto a metonímia estão relacionadas à informatividade, mas em diferentes eixos. A mudança metafórica, como já foi dito, define certas noções em termos de outras não presentes no contexto; já a mudança metonímica envolve também a definição de certas noções em termos de outras, mas, ao contrário da metáfora, essa relação está presente no contexto.

No quadro, à página seguinte, extraído de Gonçalves et al. (2007), há um resumo dos principais pontos de atuação da metáfora e da metonímia. 


\begin{tabular}{|l|l|}
\hline \multicolumn{1}{|c|}{ Metonímia } & \multicolumn{1}{c|}{ Metáfora } \\
\hline $\begin{array}{l}\text { Indicia, aponta significados que estão } \\
\text { implícitos. }\end{array}$ & $\begin{array}{l}\text { Representa membros de um domínio } \\
\text { semântico em termos de outro }\end{array}$ \\
\hline $\begin{array}{l}\text { Especifica um significado em termos } \\
\text { de outro que está presente, ainda que } \\
\text { de forma não explícita no contexto. }\end{array}$ & $\begin{array}{l}\text { Especifica uma coisa, usualmente mais } \\
\text { complexa, em termos de outra não } \\
\text { presente no contexto. }\end{array}$ \\
\hline Opera através da reanálise & Opera através da analogia \\
\hline
\end{tabular}

Quadro 05: Diferença entre metonímia e metáfora

(GONÇALVES et al., 2007, p.40)

A inferência metonímica e metafórica são complementares, são processos que ocorrem no nível cognitivo e estão relacionadas a dois mecanismos de mudança, a saber: reanálise e analogia, respectivamente.

\subsubsection{Reanálise}

Segundo Langacker (1977, apud HOPPER \& TRAUGOTT, 1993, p.40), a reanálise é definida como a "mudança na estrutura de uma expressão ou classe de expressões que não envolve qualquer modificação imediata ou intrínseca na sua manifestação superficial". ${ }^{11}$ Segundo Hopper \& Traugott (1993), um dos tipos mais simples de reanálise, e também o mais frequente em gramaticalização, é a fusão de duas ou mais formas, alterando, assim, as fronteiras das formas envolvidas. Quando uma forma sofre a alteração de fronteira, ela passa a ser reanalisada como pertencente a uma categoria diferente da sua original.

Em muitos trabalhos, a reanálise é vista quase como sinônimo de gramaticalização. Heine et al. (1991b) afirmam que tipicamente a reanálise acompanha a gramaticalização, visto que, quando um dado morfema é gramaticalizado, não somente sua posição sintáticopragmática é afetada, mas também os contextos dos quais o constituinte faz parte. Heine \& Reh (1984, p.95) propõem que haja uma separação entre reanálise e gramaticalização, devido

11 change in the structure of an expression or class of expressions that does not involve any immediate or intrinsic modification of its surface manifestation. 
ao princípio da unidirecionalidade, que é uma propriedade pertencente à última, mas não à primeira.

\subsubsection{Analogia}

Diferentemente da reanálise, a analogia refere-se à atração de formas existentes a construções também já existentes. Segundo Hopper \& Traugott (1993), para Meillet (1948 [1912]), a analogia era entendida como um processo pelo qual irregularidades na gramática, particularmente no nível morfológico, eram regularizadas. O mecanismo era visto como uma proporção ou equação do tipo: cat $:$ cats $=$ child $: X, X=$ childs $($ HOPPER \& TRAUGOTT, 1993, p.56).

Embora apenas a reanálise possa criar novas estruturas gramaticais, não se deve subestimar o papel da analogia nos estudos de gramaticalização, pois, segundo Hopper \& Traugott (1993), em muitos casos, a analogia é a primeira evidência para falantes de uma língua de que a mudança está ocorrendo.

Um exemplo da interação reanálise/analogia é o desenvolvimento da negação do francês ne...pas, citado por Hopper \& Traugott (1993, p.58):

i. a negação era realizada pela colocação da partícula negativa ne antes do verbo;

ii. um verbo de movimento negado pelo ne poderia opcionalmente ser reforçado pelo pseudo-objeto nominal pas (passo), no contexto de verbos de movimento: Il ne va (pas) (ele não vai mais nenhum passo);

iii. A palavra pas foi reanalisada como uma partícula negativa, em uma estrutura do tipo ne $\mathrm{V}_{\text {movimento }}($ pas);

iv. pas foi estendido analogicamente para novos verbos que não tinham relação com movimento, passando a ter a estrutura ne V (pas): Il ne sait pas (ele não sabe nada); 
v. A partícula pas foi reanalisada como obrigatório juntamente com ne para a negação em geral: ne V pas;

vi. Na fala vernacular, pas vem assumindo completamente a função de ne, via dois estágios: (ne) V pas (reanálise de ne como opcional), V pas (reanálise pela perda de $n e$ ), resultando: Il sait pas (ele não sabe).

Hopper \& Traugott concluem que a reanálise tem diferentes efeitos. Envolve essencialmente uma reorganização linear e sintagmática e uma mudança na regra, que não é diretamente observável. Por outro lado, a analogia envolve essencialmente uma organização paradigmática, uma mudança na colocação superficial e nos padrões de uso. A analogia torna observáveis as mudanças não observáveis da reanálise.

Um outro exemplo dados pelos autores é o desenvolvimento do auxiliar de futuro be going to:

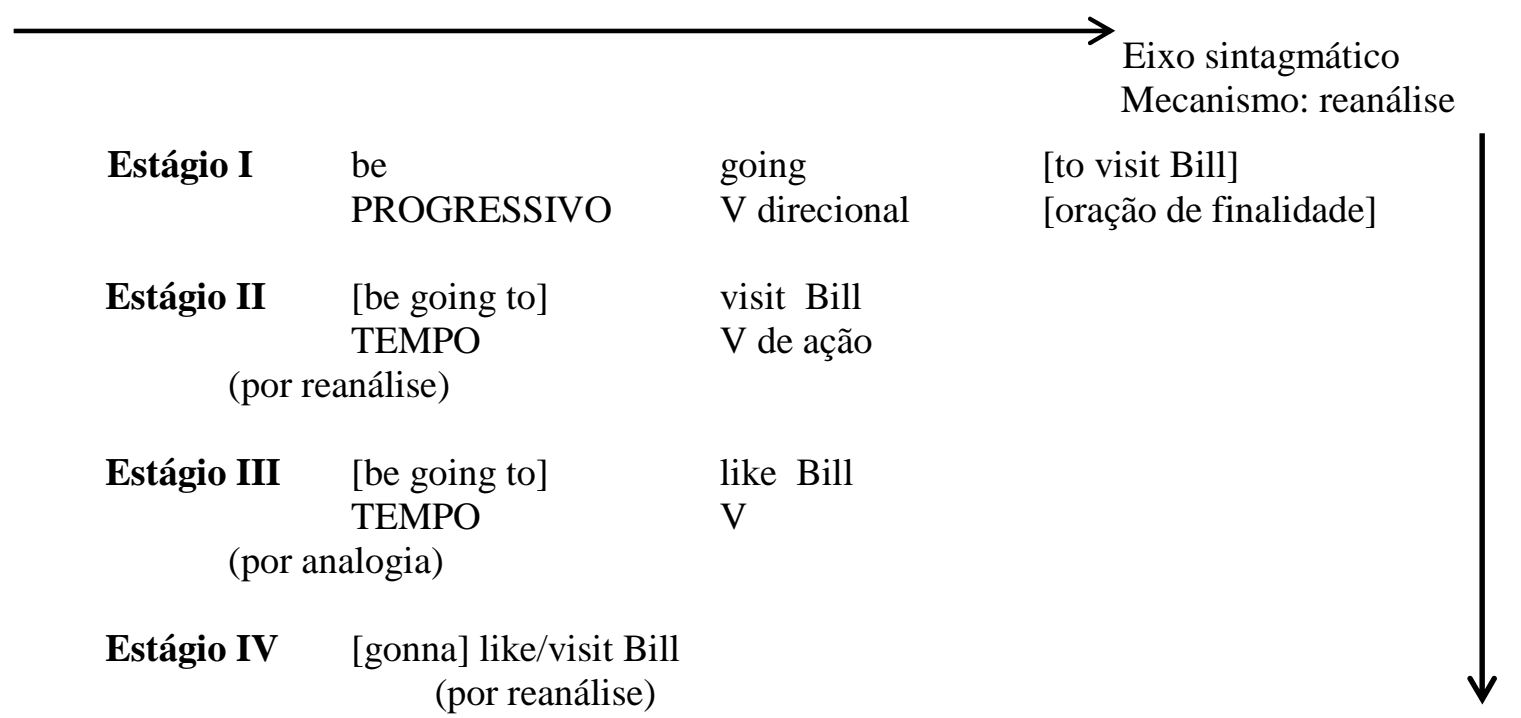

Eixo paradigmático Mecanismo: analogia 
No estágio I, há um verbo direcional e uma oração de propósito; em II, como resultado da reanálise, há um auxiliar de futuro com um verbo de atividade; em III, há uma ampliação dos tipos de verbos, via analogia; em IV, ocorre a reanálise do auxiliar complexo em um único morfema gonna.

Por meio dos exemplos acima, pode-se notar a importância da reanálise e da analogia para a mudança linguística, que são considerados importantes mecanismos da gramaticalização.

\subsection{Trabalhos anteriores}

Dedicamos esta seção à apresentação de alguns trabalhos que estudaram os itens adversativos separado ou conjuntamente de uma perspectiva diacrônica, a fim de apresentar os avanços do nosso trabalho em relação aos demais.

No tocante ao tratamento das conjunções sob o viés da gramaticalização, o trabalho pioneiro é o de Barreto (1999), intitulado Gramaticalização das conjunções na história do português. Nesse trabalho em que prevalecem análises qualitativas do fenômeno, a autora aborda o processo de mudança de 136 itens conjuncionais (24, coordenativos, 71, subordinativos, 41, correlações conjuncionais) entre os séculos XIII e XVII e século XX, agrupando-as de acordo com a semelhança de origem.

Por ser um trabalho qualitativo, a autora faz apontamentos a respeito dos processos de mudança sintático-semânticos das conjunções, não apresentando respostas conclusivas de como ocorreu ou vem ocorrendo o processo. Em relação aos itens adversativos, Barreto já os considera como conjunções adversativas, apresentando indícios de como o processo de gramaticalização foi implementado, mas, como não trabalha com análise quantitativa, não apresenta dados empíricos que comprove tal processo de mudança, que, segundo ela, se deu via metonímia. 
Na exposição que Barreto (1999) faz sobre o item porém, ela compara-o com a conjunção arcaica pero, que apresenta trajetória de mudança semelhante a de porém, conclusivo-explicativa > adversativa, mas que desaparece da língua portuguesa a partir do século XVI.

Somente no final de seu trabalho, a autora se vale de percentuais para mostrar que o processo de formação de conjunções via metonímia é altamente produtivo para $58,4 \%$ das conjunções estudadas.

O trabalho de Barreto (1999), embora referência nos estudos sobre gramaticalização de conjunções, carece de análises mais aprofundadas de itens específicos, que mostrem seus desenvolvimentos sintático, semântico e pragmático, em razão de seus objetivos que eram investigar conjuntamente diferentes tipos de conjunção.

Outro trabalho dedicado às conjunções é o de Rocha (2006), que aborda apenas as conjunções adversativas. Sua tese de doutorado intitulada Gramaticalização de conjunções adversativas em português: em busca da motivação conceptual do processo tem como objetivo analisar como ocorreu o processo de mudança semântica de mas, porém, contudo, todavia, entretanto e no entanto, via metáfora, até atingir o rótulo de conjunções adversativas. Embora Rocha as chame de conjunções, ela chama a atenção para o fato de que esses itens, com exceção de mas, não apresentam todas as características de uma conjunção, por exemplo, a fixação na fronteira oracional. Segundo ela, os itens que não concluíram o processo de gramaticalização dificilmente o concluirão, pois, como apresentam baixa frequência de uso e, quase exclusivamente, restringem-se à modalidade escrita, não serão afetados por mudanças típicas da fala.

Para defender a hipótese de motivação conceptual, metafórica, atuante na mudança das conjunções adversativas, Rocha começa por questionar a hipótese de motivação metonímica, defendida por Barreto (1999). Baseada em exemplos dados por Barreto, Rocha 
aponta algumas análises equivocadas, segundo ela, e conclui que Barreto está utilizando o mecanismo de metonímia como similar à reanálise. A autora critica o fato de Barreto não fazer uma análise quantitativa em defesa da motivação metonímica, mas também não a apresenta em defesa da motivação conceptual. Por fim, para autora, todas as hipóteses que defendem a motivação metonímica relacionam, diretamente, gramaticalização e frequência, relação essa não presente no trabalho de Barreto (1999).

A autora faz outra crítica à motivação metonímica defendida por Barreto, que seria resultante de uma derivação linear e escalar da trajetória percorrida pelo item mas. Barreto (1999) apresenta a escala de mudança de mas, a fim de esquematizar sua trajetória, mas não afirma que essa trajetória é linear e escalar. Para Rocha (2006), a metáfora atuou na mudança de magis > mas e nas mudanças que possibilitaram que o item adquirisse caráter polissêmico ao longo do tempo e também, por meio desses mecanismos, pode-se explicar o emprego de mas em contextos negativos e o motivo que fez com que mas fosse usado em contexto nos quais anteriormente era empregado sed magis.

Para buscar confirmação à sua hipótese de mudança das conjunções adversativas via metáfora, a autora faz uma análise dos adversativos que estuda, com maior ênfase para o mas, levando em consideração também o modelo cognitivo de Sweetser (1991), o qual prevê um percurso de mudança motivado por processos que contemplam mundo do conteúdo $>o$ mundo epistêmico > mundo conversacional. Ao final, por meio de análises apenas qualitativas, a autora comprova que a mudança dos itens analisados ocorreu via metáfora, na trajetória espaço (espaço do texto $)>($ tempo $)>$ texto, em que o valor semântico original dos itens são abstratizados para atingir a ideia de contrajunção.

Longhin-Thomazi (2009), no artigo intitulado Grammaticalization of conjunctions, analisa o item porém em dados do século XIII a XVI, adotando a hipótese de base metonímica da reinterpretação induzida pelo contexto, conforme aparece em Heine (2002). 
Heine (2002) propõe quatro diferentes estágios de desenvolvimento do significado mais gramatical de expressões linguísticas, quais sejam: estágio inicial, em que o item mantém o significado fonte; contexto brindging, em que há um uso específico que permite uma inferência em favor de novo significado; contexto switch, em que o novo uso é incompatível com o significado anterior; convencionalização, em que o novo significado já não precisa ser usado apenas no contexto que deu origem a ele, podendo estender-se a outros e outros contextos.

Aplicando essa trajetória de mudança a porém, Longhin-Thomazi, primeiramente, descreve o comportamento sintático-semântico do item nos séculos investigados e, por fim, analisa as ocorrências do item dentro dos quatro estágios e chega à seguinte conclusão: (i) no estágio inicial, a) porém é um advérbio juntivo fórico, participando em sentenças coordenadas, acompanhando, algumas vezes, a conjunção $e$ e, algumas vezes, completando a fronteira de diferentes componentes, b) porém é um advérbio enfático que faz correlação entre ele e orações causais/explicativas, c) porém é uma conjunção coordenativa; (ii) no contexto bridging, porém é um correlativo enfático de uma construção concessiva, podendo ser precedido de item negativo, contexto que permite a inferência de um novo significado, devido a leitura ambígua entre explicativo e adversativo; (iii) no contexto switch, porém é advérbio correlativo enfático em construções concessivas, tanto negativas quanto afirmativas. Esse contexto é imcompatível com o significado fonte; (iv) na convencionalização, porém é uma mistura de advérbio juntivo e conjunção adversativa, estágio no qual o item não requer contextos concessivos ou negativos.

Nesse trabalho, a autora não analisa a importância de determinados contextos em que porém ocorre para sua mudança linguística. Por exemplo, a autora aponta o uso de porém em contextos negativos, mas não explica a importância desse contexto para a trajetória conclusivo-explicativo > adversativo; o uso como advérbio correlativo enfático concessivo 
também é apontado como estágio intermediário para o item se tornar uma conjunção adversativa, mas não há nenhuma explicação do contexto que propiciou o uso conjuncional.

Considerando os resultados dos trabalhos brevemente expostos nesta seção, o presente trabalho deles se diferencia por analisar qualitativa e quantitativamente a trajetória advérbio > conjunção, depreendendo os elementos que contribuíram para o surgimento do significado de oposição dos itens. Além disso, discutiremos também questões pragmático-discursivas envolvidas no processo, observando as relações lógico-argumentativas veiculadas por eles.

Baseados nas diferenças que há entre os trabalhos de Rocha (2006), que advoga por uma mudança dos itens adversativos de base metafórica, e de Barreto (1999), que advoga em favor de uma mudança de base metonímica, e nas semelhanças que há entre esses dois trabalhos e o de Longhin-Thomazi (2009), propomos uma análise qualitativa e quantitativa que verifique o papel da metáfora e da metonímia no processo de mudança dos adversativos e que aponte, sincronicamente, o estatuto gramatical dos itens, por meio de uma escala comparativa entre eles. 


\section{CAPÍTULO II}

\section{ASPECTOS SINTÁTICO-SEMÂNTICOS DAS CONJUNÇÕES ADVERSATIVAS}

O objetivo desse capítulo, como já sugerido em seu título, é apresentar aspectos sintáticos e semânticos das conjunções adversativas em português, mostrando a discussão que há na literatura acerca da inclusão de itens adversativos de naturezas distintas no rol das conjunções coordenativas. Após essa discussão, trataremos do modo de articulação das orações coordenadas e, por fim, discutimos o tratamento da mudança semântica de conjunções, a partir dos trabalhos de Sweetser (1990), Traugott $(1982,1999)$ e Traugott \& König (1991).

\subsection{O estatuto das conjunções adversativas em português}

Segundo gramáticos tradicionais, entre eles Cegalla (1967), a conjunção “é uma palavra invariável que liga orações ou palavras da mesma oração. Quando a conjunção liga as orações sem fazer que uma dependa da outra, sem que a segunda complete o sentido da primeira, dizemos que a conjunção é coordenativa". Nessa definição de Cegalla não estão contemplados certos itens da língua que têm função de ligar orações semântica e/ou sintaticamente, mas que não apresentam todas as características de uma conjunção prototípica. Esses itens não contemplados por Cegalla são dotados de uma certa mobilidade dentro da oração e podem co-ocorrer com outras conjunções; exemplos desses seriam: contudo, porém, todavia, pois, no entanto, entretanto.

Já Bechara (1999, p.323) explora os itens que são considerados conjunções, mas, de fato, são unidades adverbiais que desempenham relações interoracionais e intertextuais. Segundo o autor: 
levada pelo aspecto de certa proximidade de equivalência semântica, a tradição gramatical tem incluído entre as conjunções coordenativas certos advérbios que estabelecem relações inter-oracionais ou intertextuais. É o caso de entretanto, contudo, todavia, não obstante, porém. Não incluir tais palavras entre as conjunções coordenativas já era lição antiga na gramaticografia de língua portuguesa. Perceberam que tais advérbios marcam relações textuais e não desempenham o papel conector das conjunções coordenativas, apesar de alguns manterem com elas certas aproximações ou mesmo identidade semânticas.

O autor supracitado defende a ideia de que esses itens adverbiais estabelecem apenas relações semânticas, pois eles não compartilham com as conjunções a função de ligar orações. Veja o exemplo abaixo, extraído de Bechara (1999).

"Não queremos pensar na morte, e por isso ocupamos tanto da vida"

Bechara (1999), por meio desse exemplo, explica que a conjunção $e$ tem a função de reunir as duas orações num mesmo grupo, e a conjunção por isso, como item adverbial, estabelece a relação semântica entre as duas orações.

Como se nota, enquanto alguns gramáticos não relatam a existência de diferentes itens com a função de conjunção, outros apenas mencionam a ocorrência de certos advérbios entre as conjunções, não respondendo por que esses itens, apesar de ligarem orações, têm características diferentes das conjunções prototípicas $e$, ou e mas.

Carone (1988), num estudo descritivo, explica por quais motivos itens como porém, todavia, portanto e tantos outros comportam-se de maneira diferente das demais conjunções. Segundo a autora, eles preservam algumas características da fonte adverbial, uma vez que esses itens, na fase arcaica, eram advérbios. Uma das características desses itens que se mantém é sua mobilidade posicional, o que lhes permitem ocorrer no início, no meio ou no fim da segunda oração a que se ligam. 
Neves (2000) classifica esses itens de caráter fluido como advérbios juntivos. Segundo a autora, seriam itens de valor anafórico que funcionam na oração como uma conjunção.

Entre as consideradas "conjunções" adversativas, encontra-se boa parte desses advérbios juntivos, sendo eles: porém, todavia, no entanto, contudo, entretanto. Todos eles atendem à definição clássica de uma conjunção adversativa, que é aquela que, segundo Cunha e Cintra (2001, p. 580), "liga dois termos ou duas orações de igual função, acrescentandolhes, porém, uma ideia de contraste”. Entretanto, como já discutido, essas partículas não são consideradas conjunções prototípicas, devido à mobilidade posicional e à co-ocorrência com outras conjunções, sobretudo, com a conjunção adversativa prototípica mas.

Perini (1995) elenca algumas características do adversativo porém, que podem ser estendidas para os demais itens estudados aqui, em relação a outros conectores, a saber:

- nas orações coordenadas por porém, a pontuação é obrigatória, diferentemente do que ocorre com a conjunção $e$;

- porém só coordena construções binárias;

- $\quad$ porém como o mas não coordena sintagmas nominais; ${ }^{1}$

- porém pode ocorrer em diferentes posições da segunda oração, não só no início da oração coordenada, fato esse que o aproxima dos advérbios.

Como se pode notar pela exposição acima, a literatura acerca do estatuto categorial dos itens estudados mostra que esses, embora apresentem características de conjunção, ainda preservam traços da fonte adverbial. Essa fluidez no comportamento das adversativas pode ser considerada como indício de gramaticalização que serão investigados no capítulo IV. Na

\footnotetext{
${ }^{1}$ Diferentemente de Perini (1995), Neves (2000), na Gramática de usos do Português, mostra que mas pode coordenar dois sintagmas nominais, desde que o primeiro sintagma esteja negado, como em: "não o menino mas a mãe", exemplo extraído de Neves (2000, p.756).
} 
próxima seção, continuaremos abordando essa problemática juntamente com a discussão acerca de articulação de orações.

\subsection{Articulação de orações: coordenação}

A articulação de orações é assunto de muitos estudos, entre eles Bally (1965), Carone (1988), Azeredo (1990), Hopper \& Traugott (1993), Neves (1998, 2000). Nesta seção, trataremos apenas de aspectos coordenativos da articulação, uma vez que os itens analisados no presente estudo são considerados juntores coordenativos.

Algumas gramáticas normativas (CUNHA e CINTRA, 1985; KURY, 1987; BECHARA, 1988) distinguem as orações coordenadas das orações subordinadas por meio da noção de dependência entre as orações, isto é, elas consideram as orações subordinadas dependentes, e as coordenadas, independentes.

As orações coordenadas são, no nível estrutural, independentes, mas, no nível semântico, estabelecem uma interdependência, pois o sentido que as duas orações veiculam juntas é diferente do sentido veiculado por elas separadamente. Veja o exemplo abaixo.

(10) Eu fui à aula.

Não teve aula.

Coordenação: Eu fui à aula, mas não teve.

Como se vê, a relação de sentido da terceira oração é diferente das demais. $\mathrm{Na}$ primeira e segunda orações, há apenas um relato dos fatos, já, na terceira oração, estabelecese uma noção de quebra de expectativa, pois, ao enunciar "eu fui à aula", cria-se uma expectativa de que teve-se aula, mas essa suposição não é confirmada com a oração "mas não teve". 
Na literatura linguística, há o trabalho de Hopper \& Traugott (1993) que trata do modo como as orações se articulam. Os autores dividem as orações em três modos de articulação:

a) Parataxe: independência relativa, exceto pelos limites pragmáticos de "fazer sentido" ou relevância. Os itens analisados neste trabalho se encontram dentro desse modo;

b) Hipotaxe: interdependência, em que há um núcleo e uma ou mais margens, ou orações, que não se sustentam sozinhas e são, por esse motivo, dependentes. No entanto, elas não estão totalmente incluídas dentro de qualquer constituinte do núcleo;

c) Subordinação: em sua forma extrema, encaixamento. Em outras palavras, dependência completa, em que uma margem está totalmente incluída dentro de um constituinte nuclear.

Os autores organizam esses três grupos em um cline de combinação de orações, com características definidas a partir da combinatória de traços de dependência e de encaixamento, como mostrado abaixo.

$\begin{array}{rcc}\text { Parataxe } & \text { Hipotaxe } & \text { Subordinação } \\ \text { - dependente } & + \text { dependente } & + \text { dependente } \\ \text { - encaixada } & \text { - encaixada } & + \text { encaixada }\end{array}$

Embora reconheçamos a relevância da proposta de Hopper \& Traugott acerca da articulação de orações, o foco deste trabalho é mostrar o comportamento de alguns itens, apenas, dentro da parataxe, uma vez que não há usos deles em outros modos de articulação.

Bally (1965 apud CARONE, 1991) afirma que um critério importante para explicar a coordenação é a relação de sentido que essa veicula. Para ele, a colocação de dois enunciados lado a lado é justificada, primordialmente, pelo sentido que surge dessa junção, mesmo nas orações chamadas justapostas, aquelas que ocorrem unidas sem a intermediação de qualquer elemento conectivo. 
Para o autor, duas orações se coordenam quando X (primeira oração) é retomado por Y (segunda oração) por meio de uma oração explícita ou por meio de uma conjunção coordenativa, a que o autor denomina "anafórico". Sendo assim, a coordenação é caracterizada por um movimento retrojetivo, ou seja, o representante de $\mathrm{X}$ dentro de $\mathrm{Y}$ "olha para trás" e conclui o que será dito. Por causa desse movimento retrojetivo, a ordem das orações não pode deixar de ser rígida: primeiramente $\mathrm{X}$ e, depois, Y. O autor considera também o fato de que esse representante de X é um item que, no início, tem características de adjunto adverbial, trazendo circunstância para a oração. Esse item só se cristaliza como conjunção quando perde as características da fonte adverbial e assume as características de uma conjunção coordenativa prototípica.

As conjunções coordenativas prototípicas $e, o u$, mas têm suas posições fixas no início de Y, enquanto a maioria dos outros elementos juntivos - porém, contudo, todavia, entretanto, no entanto, etc -, como apontado na seção anterior, é dotada de certa mobilidade, traço característico de sua fonte adverbial, podendo ocorrer no início, no meio ou no fim de Y. Além dessa característica, itens como porém admitem co-ocorrência com os outros elementos coordenativos, como, e porém, mas contudo, e todavia, em que o coordenativo prototípico ocupa a primeira posição e outros, a segunda. De uma forma geral, itens como porém, entretanto, todavia, por conseguinte são considerados casos de gramaticalização e, quanto mais avançado no processo se encontram esses itens, maior a probabilidade de eles se fixarem no início de Y.

Neves (1998, p.51) constata que itens como entretanto, contudo, todavia permitem a co-ocorrência com as conjunções $e$, mas, fato esse que, num cline de gramaticalidade, os afasta do rol das conjunções prototípicas. Já porém permite a co-ocorrência com a conjunção 
mas, no entanto rejeita a combinação com a conjunção $e^{2}$, comportamento que faz com que porém não faça parte do mesmo grupo de entretanto. Segundo a autora, essa diferença no comportamento dos itens analisados em relação à co-ocorrência com as conjunções $e$ e mas faz com que porém se encontre num estágio de gramaticalização mais avançado que os itens à sua esquerda.

A autora apresenta um cline de gramaticalidade das conjunções coordenativas, no qual ela as dispõe em diferentes pontos, pois essas se encontram em diferentes estágios em direção do valor conjuncional.

\section{entretanto, contudo, todavia, etc $\longrightarrow$ porém $\longrightarrow$ mas $\longrightarrow$ e, ou}

Quanto ao tipo de unidades articuladas numa estrutura coordenada, há consenso que as conjunções coordenativas coordenam unidades funcionalmente equivalentes. Neves (1998) aponta que a diferença entre as conjunções $e$, ou e mas está no tipo de elementos que coordenam. As conjunções $e$ e ou permitem coordenar não só frases, orações, sintagmas de diversos tipos, mas também quaisquer elementos que tenham o mesmo estatuto; mas, por sua vez, guardando traços de sua fonte adverbial, não coordena elementos de mesmo estatuto gramatical, como *de mas para, *dois mas três, ou seja, mas não aceita qualquer tipo de coordenação, coordena preferencialmente predicados.

Uma característica típica da coordenação é a presença de pausa, morfema suprasegmental, que separa Y de X. As conjunções como $e$ e $o u$ são precedidas por uma pausa leve, dispensando o registro desta na escrita. Já com as conjunções mas, pois e logo ocorre uma pausa mais marcante que as precede, fazendo com que essas conjunções se liguem mais fortemente a Y do que a X. Para certas conjunções como contudo, porém, portanto, entretanto há registro de pausa antes e, às vezes, depois delas. A ocorrência dessa última pausa torna a pausa anterior mais profunda, sendo marcada na escrita com ponto final ou ponto-e-vírgula.

\footnotetext{
${ }^{2}$ Numa busca rápida pela internet de casos em que porém combina com $e$, foram encontrados, em média, 103.000 casos, como "Comprei um celular motorola V3 e, porém a qualidade da foto dele é bem INFERIOR que o do motorola V3 BLACK!".
} 
Carone (1988, p.57) afirma que a pausa mais profunda é reforçada por uma entoação descendente no primeiro segmento, e ascendente no início do segundo.

Em relação aos coordenativos adversativos, a característica semântico-pragmática presente em todos eles é a relação de contraste por quebra de expectativa, o que faz com que o interlocutor se surpreenda com a informação dada pelo locutor. Van Dijk (1977), ao analisar alguns conectivos contrastivos ingleses, como but, though, although, yet, nevertheless, whereas, in spite of, notwithstanding, anyway, descreve algumas características deles: (i) expressam o contraste estabelecido entre as propriedades e os cursos do evento com as expectativas normais do mundo; (ii) indicam estados ou cursos que são inesperados ou indesejáveis; (iii) expressam a não-satisfação de condições possíveis, prováveis ou necessárias. Ao quebrar a pressuposição, o locutor cancela qualquer conteúdo pressuposto pelo interlocutor, mudando, consequentemente, a informação pragmática desse. Segundo Dik (1989), essa mudança pode acrescentar, substituir ou eliminar peças de informação prévia do interlocutor ou torná-lo consciente de alguma informação que tinha, mas de que não estava consciente.

As características aqui apresentadas que permitem definir uma estrutura coordenada adversativa são:

- construção binária: a estrutura coordenada é constituída por um par de orações - X e Y (PERINI, 1995; CARONE, 1988);

- relação de sentido entre $X$ e Y: o sentido emergido do todo é diferente do sentido de cada uma das partes (AZEREDO, 1990);

- movimento retrojetivo: o elemento que faz a ligação das duas orações precisa "olhar" para a primeira oração para, a partir daí, concluir a idéia (BALLY, 1965); 
- rigidez na sequência: para o elemento coordenativo estabelecer a relação de sentido entre as orações, é necessário que X venha antes de Y (BALLY, 1965);

- pausa: ocorre uma pausa mais marcante que antecede os itens adversativos, registrado na escrita por vírgula, ponto-e-vírgula ou ponto final (CARONE, 1988);

- relação de contraste por quebra de expectativa (coordenação por adversatividade): nessa relação, o interlocutor se surpreende com o que o locutor afirma na oração adversativa, pois não era esperada a conclusão apresentada (VAN DIJK, 1977; DIK, 1989).

\subsection{A mudança semântica das conjunções}

\subsubsection{A proposta de Sweetser $(1988,1990)$}

Em seu texto de 1988, Sweetser questiona afirmações em gramaticalização a respeito do enfraquecimento semântico ou perda semântica e também sobre a regularidade da mudança semântica. Para ela, um item, ao passar por um processo de mudança semântica, não perde totalmente traços do domínio fonte; alguns traços são mantidos de forma opaca. Um exemplo dado pela autora para sustentar essa afirmação é a mudança semântica do verbo to go, do inglês, que, do sentido fonte de movimento espacial, físico, passa, por meio de uma projeção metafórica, a significar futuridade. Ainda que o verbo tenha perdido alguns traços do domínio fonte, são mantidos traços como: linearidade entre dois pontos, antes, de caráter espacial, agora, de caráter temporal; posição do falante, que sempre se coloca na base e estabelece a projeção, seja espacial ou temporal.

Em estudo de 1990, baseada em trabalhos de semântica histórica, Sweetser (1990, p. 18) afirma que os resultados desses trabalhos atestam regularidades na mudança semântica e constituem evidência de que ela é estruturada pela cognição. Diante dessa constatação, a autora propõe um modelo de projeção metafórica que estrutura os itens da língua em três 
domínios, a saber: conteúdo (sócio-físico), epistêmico (raciocínio lógico) e conversacional (ato de fala). Esses domínios são organizados unidirecionalmente, do conteúdo [+ físico] para o conversacional [+ psicológico], passando pelo epistêmico, segundo o cline: conteúdo (sociofísico) > epistêmico (raciocínio lógico) > conversacional (ato de fala).

Segundo a autora, a passagem de um domínio a outro é marcada por estágios de polissemia, devido ao uso metafórico de um item em diferentes domínios, ou seja, se um item tem um significado A e depois passa a ter um significado B, houve um estágio em que esse item significou A e B simultaneamente. Para ela, as transferências metafóricas são reflexos das nossas experiências no mundo físico que se organizam para representar ideias abstratas.

Ao tratar das conjunções and, or e but, a autora defende que elas podem ser interpretadas de modo diferente, a depender do seu emprego. Os exemplos da conjunção adversativa inglesa $b u t$, dados pela autora, ilustram o funcionamento da conjunção em dois domínios, o epistêmico e o conversacional, como mostram (11) e (12), respectivamente.

(12) John keeps six boxes of pancake mix on hand, but never eats pancakes. John tem seis misturas de panquecas, mas ele nunca come panquecas. (= Do fato de ter seis misturas de panquecas conclui-se que John come panquecas, informação que se choca com a outra informação de que ele nunca come panquecas.)

(13) King Tsin has a great mu shu pork, but China First has excellent dim sum. King Tsin tem um ótimo mu shu pork, mas o China First tem um excelente dim sum. (= A sugestão indireta inicial de comer no King Tsin choca aparentemente com a sugestão indireta subsequente de comer no China First; ambas sugestões não podem, presumivelmente, ser seguidas simultaneamente.)

Em (12), ocorrência representativa do nível epistêmico, a premissa disponível de que John tem seis misturas de panquecas se choca com a conclusão de que ele nunca comeu panqueca. Já em (13), representativa do nível conversacional, o uso de but (mas) sinaliza a consciência do falante de apresentar lado a lado, pelo menos, dois atos de fala parcialmente discordantes. O choque aparente, em (13), está no fato de oferecer ao interlocutor opções , já 
que, segundo Lakoff (1972, 1973 apud SWEETSER, 1990), é educado apresentar algumas opções e permitir que o interlocutor escolha.

Segundo a autora, o motivo de não ter exemplo de but no domínio do conteúdo é devido ao fato de que, se dois estados coexistem no mundo real e a conjunção but apresenta ambos como verdadeiros, então esses estados não podem se chocar no nível do mundo real.

Retomando a ideia de que os traços do significado fonte de um item são mantidos, é preciso esclarecer que não necessariamente eles serão percebidos pelo falante, como, por exemplo, no caso de algumas adversativas com porém, em que o significado fonte de conclusivo-explicativo já está tão opacificado que o falante não consegue recuperá-lo.

\subsubsection{Elizabeth Traugott $(1982,1999)$ e E. Traugott \& E. König (1991) - a mudança semântica em gramaticalização}

Traugott (1982) aborda algumas mudanças linguísticas de palavras da língua inglesa sob o prisma dos componentes funcionais da linguagem, propostos por Halliday e Hasan (1976). Esse modelo semântico-funcional apresenta três componentes, a saber:

- Proposicional (ideacional para Halliday e Hasan): engloba os recursos linguísticos que permitem falar do mundo exterior à linguagem como, por exemplo, elementos sujeitos à verificação referencial (dêiticos de lugar, tempo e pessoa).

- Textual: refere-se aos recursos disponíveis para a criação de um discurso coeso, tais como conectivos, anafóricos, catafóricos, topicalizadores e complementizadores.

- Expressivo (interpessoal para Halliday e Hasan): diz respeito aos recursos que a língua tem para o falante expressar atitudes/avaliações pessoais sobre o que está sendo dito, sobre o próprio texto ou sobre os participantes da situação discursiva. Inclui os 
modalizadores, operadores argumentativos, marcadores de pressuposição e índices de polifonia.

Tendo em mente esse três componentes semântico-funcionais, a mudança de significado ocorrerá de um componente para o outro. Para explicar melhor a trajetória de mudança de alguns itens, segundo esse modelo, Traugott (1982) apresenta duas hipóteses:

- Hipótese A: se ocorrer uma mudança semântica no processo de gramaticalização, é mais provável ser do menos pessoal ${ }^{3}$ para o mais pessoal do que o contrário.

Essa hipótese pode ser comprovada por meio de vários exemplos de muitas línguas. Um dos exemplos citados pela autora é a trajetória aspecto > tempo, em que tempo é mais pessoal que aspecto, no sentido de estar ancorado deiticamente no ato de fala.

- Hipótese B: se ocorrer uma mudança semântica no processo de gramaticalização, será de um componente semântico-funcional para outro. Então tal mudança é mais provável ocorrer do nível proposicional para o expressivo, por meio do textual, do que na direção inversa.

Segundo a autora, nos processos de gramaticalização, a mudança de significado tem, então, a seguinte trajetória: proposicional $>$ (textual $)>$ expressivo.

Um exemplo que ilustra a passagem do proposicional para o expressivo por meio do componente textual é o desenvolvimento do item while, que pode ser descrito da seguinte maneira:

\footnotetext{
${ }^{3}$ Entenda "mais pessoal" como "mais ancorado no contexto do ato de fala".
} 
(14)

$\begin{array}{ccccc}\begin{array}{c}\text { pa hwile pe } \\ \text { (uso nominal e adverbial) }\end{array} & > & \text { While } & \text { while } \\ \text { Proposicional } & > & \text { Textual } & > & \text { Expressivo }\end{array}$

Traugott \& König (1991, p.208), revisando essa proposta inicial, identificaram três tendências semântico-pragmáticas em gramaticalização:

Tendência I: significados baseados em descrições de situações exteriores > significados baseados em situações internas (avaliativas, perceptivas, cognitivas).

Essa mudança segue de uma situação física (concreta) para uma situação perceptual (cognitiva). Tem-se como exemplo o desenvolvimento de termos espaciais em advérbios ou preposições, podendo se desenvolverem em conjunções.

Tendência II: significados baseados em situações externas ou internas > significados baseados em situações textuais (coesivas).

Os autores citam como exemplo dessa segunda tendência o item after, que, de conectivo temporal, passa a funcionar como marcador textual, desempenhando relações coesivas.

Tendência III: significados tendem a ser fundados nas crenças subjetivas ou atitudes dos falantes a respeito da situação.

Como exemplo dessa tendência, tem-se relações causais e concessivas expressam, essencialmente, atitudes subjetivas do falante em relação ao que está sendo dito. 
Diante dessas tendências, os autores chegam à formulação de que as mudanças semânticas que acompanham os processos de gramaticalização seguem uma trajetória unidirecional, que aponta para o crescente fortalecimento da expressão subjetiva do falante, numa trajetória do tipo:

Significados
identificáveis nas
situações extralin-
guísticas $\quad \begin{gathered}\text { Significados fundados } \\ \text { na marcação textual }\end{gathered} \quad \begin{gathered}\text { Significados fundados na } \\ \text { atitude ou crença do falante a } \\ \text { respeito do que é dito }\end{gathered}$

Para os autores, a motivação do processo está no princípio da informatividade ou relevância, que é o fator responsável por fazer com que os falantes busquem maior clareza, por meio dos itens gramaticais, e que selecionem a interpretação mais informativa ou relevante.

Os autores também argumentam contra a noção de perda semântica que é muito apontada na literatura recente. Para eles, o processo de mudança semântica pode ser acompanhado de uma perda de significado, por um lado, mas há sempre um ganho, por outro, e é nesse último ponto que o pesquisador tem de se basear.

Em Traugott (1999), a autora apresenta os processos de subjetivização e intersubjetivização como meios para o processo de mudança semântica de um item. A subjetivização é definida, pela autora, como o processo pelo qual significados novos são desenvolvidos para lexemas já existentes, com o propósito de codificar as atitudes baseadas no mundo comunicativo do evento do ato de fala, e não em aspectos do evento ou situação referente ao mundo real.

Alguns autores abordam a noção de intersubjetividade que pode ser entendida como uma propriedade da subjetivização. Para Schiffrin (1990), a intersubjetividade emerge da interação entre o que o agente faz e a interpretação pública de toda a informação disponível. 
Nuyts (1998) define a "intersubjetividade" como a evidência conhecida ou acessível ao grande número de pessoas que dividem a mesma conclusão com o falante. Por último, Traugott (1999) concebe a intersubjetividade como a atenção do falante para as atitudes do ouvinte. A intersubjetivização é o processo pelo qual os significados, com o tempo, passam a codificar as atitudes do falante com relação a atenção do ouvinte.

Em suma, enquanto a subjetivização está centrada no falante, a intersubjetivização está centrada no ouvinte. Esses dois processos são complementares, no sentido de que a intersubjetivização não existe sem um grau de subjetivização, e vice-versa. 


\section{CAPÍTULO III \\ PROCEDIMENTOS METODOLÓGICOS}

Apresentamos, nesse capítulo, os procedimentos metodológicos adotados em nossas análises. Num primeiro momento, relatamos os procedimentos para a composição dos corpora. Na segunda seção, atemos-nos aos procedimentos para a apuração da frequência considerando os critérios de análise adotados no presente trabalho. Por fim, apresentamos em detalhe esses critérios de análise, em formato de grupo de fatores.

\subsection{Composição dos corpora}

Os dados dos itens adversativos porém, contudo, todavia, entretanto e no entanto foram extraídos de textos escritos, representativos dos três períodos da língua portuguesa, sendo: período arcaico (séc XIII ao XV), período moderno (séc XVI e XVII) e período contemporâneo (séc XVIII ao XXI). ${ }^{1}$

Para abarcarmos todos esses períodos, foram selecionados textos de natureza diversa dos séculos XIII ao XIX ${ }^{2}$, pertencentes ao Banco Informatizado de Textos, do Projeto para a História do Português (BIT-PROHPOR) ${ }^{3}$, organizado pelos pesquisadores da Universidade Federal da Bahia, sob responsabilidade da Professora Doutora Rosa Virgínia Mattos e Silva, os quais foram complementados pelo "Corpus diacrônico do Português", organizado por Longhin-Thomazi $(2007)^{4}$, uma vez que o primeiro não apresentava muitas páginas editadas por século. Para a amostra do século XX, foram coletados dados de textos escritos (crônicas e

\footnotetext{
${ }^{1}$ Essa periodização é a mesma adotada pelos pesquisadores do BIT-PROHPOR para organização do corpus que nos serviu de fonte para o levantamento dos dados.

${ }^{2}$ Os tipos de textos encontrados nas sincronias investigadas são: carta oficial, crônica, relatório de repartição pública, discurso religioso, testemunho, discurso científico, discurso político, relatório de guerra e relatório de viagem.

${ }^{3}$ Os textos que compõem esse corpus foram editados, a partir de cópias fac-similadas, com rigor filológico pelos pesquisadores do projeto ou por alunos de pós-graduação que desenvolvem esse trabalho como parte de um projeto de pesquisa.

${ }^{4}$ Esse corpus foi feito sob os auspícios da FAPESP, e disponível no site www.cdp.ibilce.unesp.br
} 
correspondências) da primeira metade do século XX, provenientes do Banco Lexicográfico da UNESP-Araraquara. Por fim, como representantes da sincronia atual, foram selecionados textos de caráter opinativo-argumentativo (editorais, crônicas jornalísticas e cartas de painel de leitores) ${ }^{5}$ do jornal Folha de São Paulo. ${ }^{6}$

Foram selecionadas, em média, 300 páginas, em formato Word, de textos representativos de cada um dos oito primeiros séculos (XIII ao XX), e, do século XXI, foram selecionados quatro exemplares por ano do jornal Folha de São Paulo, de 2001 a 2009, totalizando 288 páginas representativas do século. ${ }^{7}$

É importante dizer que a pesquisa com dados históricos encontra certas dificuldades e limitações, tais como:

1) representatividade de diferentes gêneros textuais que pode ser uma instância que favorece a manifestação, em menor ou maior grau, de alguns fenômenos linguísticos, como, por exemplo, o caso de ocorrências do juntivo contudo, que apresenta baixa frequência em todos as sincronias investigadas;

2) embora o corpus esteja em grande parte informatizado, a identificação dos itens investigados, para posterior extração do contexto maior de sua ocorrência não é facilitada, em razão das diferentes grafias em séculos mais iniciais (XIII ao XV), o que exige a busca “manual” por meio da leitura minuciosa de todos os textos provenientes desses séculos; ${ }^{8}$

3) falta de garantia na interpretação adequada de algumas ocorrências dos séculos passados, as quais requerem informações extralinguísticas, nem sempre possível de serem recuperadas no cotexto.

\footnotetext{
${ }^{5}$ A escolha por trabalhar com crônicas e cartas nos séculos XX e XXI deve-se ao fato de terem sido os gêneros que mais se sobressaíram no corpus diacrônico.

${ }_{7}^{6}$ Os textos pertencentes a esse último corpus foram coletados por mim.

7 A referência dos textos investigados pode ser verificada no Anexo 1, em que, antes da referência bibliográfica de cada texto, há um sigla que os identifica nas análises.

${ }^{8}$ É o caso, por exemplo, de porém, que, entre os séculos XIII ao XV apresenta as seguintes variações ortográficas: por en, por em, poren, porem, por ende, porende, por ende, porê, porếde.
} 


\subsection{Apuração de frequência e análise dos dados}

Na literatura mais recente sobre gramaticalização (BYBEE et al., 1994; BYBEE, 2003), há vários estudos que apontam a importância do aumento da frequência de uso dos itens em gramaticalização.

Bybee (2003) afirma que uma das características notáveis dos itens gramaticais nas construções em que eles ocorrem é sua frequência textual extremamente alta quando comparada à frequência típica dos itens lexicais. Esse aumento na frequência de uso de uma forma surge como resultado de um aumento nos números e tipos de contexto em que ela é empregada. A frequência não resulta na gramaticalização, mas constitui uma contribuição primária para o processo.

Nesse trabalho, Bybee apresenta uma nova definição de gramaticalização que considera a importância do papel da repetição durante o processo de gramaticalização e caracteriza-o como o processo pelo qual uma sequência de palavras ou morfemas altamente frequentes se torna automatizada como uma unidade de processamento singular.

A autora, a partir de Haiman (1994), apresenta os aspectos da ritualização, que são resultados do processo de repetição, sendo eles:

- habituação: esvaziamento de um objeto cultural ou prática da sua força e frequentemente sua significação original;

- automatização: processamento de uma sequência como bloco único;

- redução da forma: a redução ocorre por meio do enfraquecimento de gestos individuais e reorganização de uma série de gestos separados em uma unidade automatizada;

- emancipação: a função original, mais instrumental, cede lugar à função mais simbólica inferida do contex to em que a unidade ocorre. 
Segundo Bybee, esses aspectos de ritualização aplicados aos processos de gramaticalização colaboram para argumentar que a repetição frequente de um item representa importante papel nas seguintes mudanças:

i. a frequência de uso leva ao enfraquecimento de forças semânticas pela habitualidade, processo pelo qual um organismo deixa de responder no mesmo nível ao estímulo repetido;

ii. mudanças fonológicas de redução e fusão de construções gramaticalizadas são condicionadas por sua alta frequência e por seu uso em porções do enunciado que contêm informação velha ou de fundo;

iii. o aumento da frequência confere maior autonomia à construção, o que significa que componentes individuais da construção enfraquecem ou perdem sua associação com outras ocorrências do mesmo item;

iv. a perda de transparência semântica que acompanha a separação entre os componentes da construção gramaticalizada e seus congêneres lexicais permite o uso da forma em novos contextos com novas associações pragmáticas, levando a mudança semântica;

v. a perda de autonomia da forma frequente a torna mais enraizada na língua e frequentemente condiciona a preservação de algumas das características morfossintáticas obsoletas.

Para a contagem da frequência, são utilizados dois métodos: um relacionado à frequência token e o outro à frequência type. Token, ou frequência textual, é a contagem de todas as ocorrências do item, independentemente do significado que elas veiculam. A 
frequência type refere-se à contagem de um padrão particular de dicionário; em outras palavras, o significado ou a função de um item ou construção.

Uma propriedade muito notada de construções gramaticalizadas é o seu aumento em frequência type. Como consequência, a frequência token também cresce. Tão importante quanto o aumento da frequência type é a alta frequência token das formas gramaticalizadas, que é identificada como uma das causas que desencadeia muitas mudanças na forma e na função das construções gramaticalizadas.

Bybee afirma que, apesar de a repetição ser um universal no processo de gramaticalização, e suas consequências para a representação cognitiva serem os maiores fatores na criação da gramática, ela sozinha não pode dar conta de todos os universais da gramaticalização. Não é somente o fato da repetição que é importante, mas também o que é repetido.

Para a análise quantitativa elaborada nesse trabalho, o processamento de dados foi feito eletronicamente, empregando-se o "pacote" estatístico GOLDVARB e seus subprogramas para a identificação das frequências token e type, bem como para a descoberta de correlações entre os critérios de análise propostos por meio dos grupos de fatores. As ocorrências foram selecionadas no corpus e codificadas, de acordo com códigos mnemônicos atribuídos a cada um dos fatores que representam os critérios de análise. Nessa fase, o emprego da noção de grupo de fatores emprestada da Sociolinguística Variacionista é de fundamental importância, pois permite manipular uma grande quantidade de dados, ao mesmo tempo em que garante que todos os dados sejam analisados à luz dos mesmos critérios.

A fase precedente à quantificação dos dados é também importante, já que pressupõe, de antemão, uma leitura qualitativa dos dados, que permite, após os resultados frequenciais, compreender e explicar as estatísticas numéricas oferecidas pelo programa. 
A partir da análise dos resultados frequenciais oferecidos pelo programa, analisamos os itens adversativos que estão mais próximos do comportamento conjuncional e os que estão mais distante, propondo, assim, um cline de gramaticalidade para os itens. Por meio da análise unidimensional oferecida pelo programa e do cruzamento dos grupos de fatores, extraímos os percentuais e verificamos os fatores relevantes para a mudança sintático-semantico-pragmática de porém, contudo, todavia, entretanto e no entanto.

\subsection{Por uma definição dos juntivos mais gramaticalizados}

Cada ocorrência selecionada foi submetida aos grupos de fatores apresentados a seguir, os quais permitiram estabelecer uma escala de gramaticalidade para cada um dos itens e também entre eles.

Grupo 01: relação semântico-discursiva

Para o conjunto de itens estudados, foram encontradas 12 diferentes funções semânticas ${ }^{9}$, cuja distribuição por entre eles segue apresentada no quadro 06, abaixo. Ocorrências exemplificativas de cada uma dessas funções seguem apresentadas e discutidas por juntivo de (16) a (20).

\footnotetext{
${ }^{9}$ Essas funções foram recuperadas a partir dos trabalhos de Barreto (1999), Rocha (2006), pesquisas em gramáticas históricas e dicionários etimológicos, tais como Said Ali (1964), Cunha (1986).
} 


\begin{tabular}{|c|c|c|c|c|c|}
\hline $\begin{array}{r}\text { Função } \\
\text { Semântica }\end{array}$ & $\begin{array}{l}\text { Porém } \\
\text { (16) }\end{array}$ & $\begin{array}{c}\text { Todavia } \\
\text { (17) }\end{array}$ & $\begin{array}{c}\text { Contudo } \\
\text { (18) }\end{array}$ & $\begin{array}{c}\text { No entanto } \\
\text { (19) }\end{array}$ & $\begin{array}{c}\text { Entretanto } \\
\text { (20) }\end{array}$ \\
\hline $\begin{array}{l}\text { Lugar figurado } \\
\text { (Barreto, 1999) }\end{array}$ & & & & (19a) & $(20 a)$ \\
\hline $\begin{array}{l}\text { Temporal } \\
\text { (Barreto, 1999) }\end{array}$ & & & & & (20b) \\
\hline $\begin{array}{l}\text { Modo I } \\
\text { (de todo modo) } \\
\text { (Barreto, 1999) } \\
\end{array}$ & & (17a) & & & \\
\hline $\begin{array}{l}\text { Modo II } \\
\text { (completamente) } \\
\text { (Barreto, 1999) }\end{array}$ & & (17b) & & & \\
\hline $\begin{array}{l}\text { Fórico } \\
\text { (Barreto, 1999) }\end{array}$ & & & (18a) & (19b) & \\
\hline $\begin{array}{l}\text { Conclusivo } \\
\text { (Barreto, 1999) }\end{array}$ & & & (18b) & & \\
\hline $\begin{array}{l}\text { Conclusivo- } \\
\text { explicativo } \\
\text { (Mattos e Silva, } \\
\text { 1984) }\end{array}$ & (16a) & & & & \\
\hline Relação ambígua & (16b) & $(17 \mathrm{c})$ & $(18 \mathrm{c})$ & & \\
\hline Adversativo & $(16 c)$ & $(17 d)$ & (18d) & $(19 c)$ & $(20 c)$ \\
\hline Reforço & $(16 \mathrm{~d})$ & $(17 \mathrm{e})$ & $(18 \mathrm{e})$ & $(19 d)$ & \\
\hline
\end{tabular}

Quadro 06: Matriz de traços semânticos que se aplicam aos diferentes advérbios juntivos

Das 10 funções semânticas apontadas no quadro 06, porém realiza as seguintes funções: conclusivo-explicativo, ambíguo, adversativo e reforço, como seguem exemplificadas em (16).

(16) Funções semânticas de porém

a. Toda molher uyuuoa, pero que aya padre ou madre, possa-sse casar sem mandado d'elles, se quiser, e non aya nenhua pea poren de a desherdarem. (13LA, p.8)

b. O dia em que el Rey auia dauer sua rreposta, foi assijnado aaquelles senhores e leterados, no quall cada huu disse sua emtemçom, segundo a camtijdade de seu emtemder e saber, nom porem afastados de huu proposito. (15CTC, p.9)

c. Não se pode negar que o Banco Central vem procurando ampliar suas operações no mercado de câmbio com vistas a conter a forte valorização do real. Os resultados, porém, têm sido pouco expressivos. (21FSP, fev.05)

d. Pela boniteza da impressão, pela generosidade do papel, pelo conselho encantador das gravuras, os bons livros modernos não querem nos obrigar apenas a saber a vida, mas a gostar dela porém. (20GN, p.177) 
Na ocorrência (16a), representativa do século XIII, porém estabelece uma relação conclusivo-explicativa entre os dois enunciados: no primeiro enunciado, o locutor dirige o seu argumento em favor do casamento de qualquer mulher, sem consentimento dos pais, e, no segundo enunciado, o locutor apresenta a conclusão desse argumento: a mulher não deve ser penalizada pelo seu casamento sem consentimento dos pais e, para isso, o locutor se utiliza de poren que, nessa ocorrência, tem valor anafórico de por isso.

Em (16b), temos uma ocorrência que permite tanto uma leitura conclusivoexplicativa como uma leitura adversativa. Numa leitura conclusivo-explicativa, teríamos que, embora os senhores e letrados dissessem suas intenções, segundo o entender e o saber deles, eles não estavam por isso afastados de um propósito. Já, numa leitura adversativa, porém estabelece uma relação de negação de inferência, uma vez que, a partir do primeiro enunciado, o interlocutor conclui que os senhores e letrados fizeram suas intenções levando em consideração, apenas, o entender e o saber deles, no segundo argumento, então, o locutor nega essa inferência feita pelo interlocutor e mostra que, na verdade, os senhores e letrados tinham um propósito com as suas intenções.

Porém, em (16c), funciona com um adversativo, marcando uma relação de contraargumentatividade, pois, o argumento apresentado no primeiro enunciado direciona o interlocutor para a conclusão de que a ação do Banco Central de conter a valorização do real está sendo satisfatória, mas, no segundo enunciado, o argumento segue em direção oposta ao do primeiro enunciado, mostrando que não são tão satisfatórios os resultados da ação do Banco Central.

Como exemplo de reforço, temos a ocorrência (16d), em que porém reforça o valor adversativo já expresso pelo mas, item principal da classe dos adversativos. 
Todavia, Em todos os corpora investigados, encontra-se associado as funções de: advérbio de modo I (de todo modo), advérbio de modo II (completamente), ambíguo, adversativo e reforço, como exemplificadas pelas ocorrências em $(17)^{10}$.

\section{Funções semânticas de todavia}

a. Assi andaram todo aquel dia, que nom falaram em al, senom que dizia Erec que todavia teeria sua promessa; mais muito se maravilhava que era o que queria pidir. (13DSG, p.10)

b. Toda cousa mouil que omẽ mandar aas eygreyas ou a proues ou a outros logares d'esmolna ou pera quando se ordiar crerigo ou pera uoda de leygo, o que mãdar seya teudo de o dar todauia. (13FR, p.68)

c. - Ai, senhoram disse Meraugis, eu soõ ainda novel cavaleiro e soõ de pequena nomeada, e rogo-vos por Deus que me leixedes ir convosco ataa que veja que vós havedes mester de companha, ca o coraçom me diz que vos há-de contecer alguu mal.

- Nom farám, disse Erec, se Deus quiser.

- Todavia, disse Meraugis, vos rogo que me leixedes convosco ir.

E el lho outorgou. (13DSG, p.10)

d. Posso dar rumo à minha vida sem a miragem diante dos olhos. Em fins deste abril devo vender uma casa em São Paulo e então te mandarei o conto. Não garanto, todavia. As coisas falham 9 vezes para acertar 1/2: não obstante estive em São Paulo há poucos dias e ficou fechado o negócio, dependendo do recebimento por parte do comprador de uma letra do Governo, que vence nos fins de abril. (20CE-C, p.5)

e. Como assi seja que em duas maneiras se faça a alguém enjuria: hua per engano, e outra per força, o engano perteece aa rraposa, e a força ao liom, e cadahua delas he muy estranha da natureza do homem. Mas todavia o engano he mais digno de sseer avorrecido. (15LO, p.17)

Em (17a), todavia estabelece uma relação de modo, podendo ser parafraseado por

"de todo modo". No trecho apresentado acima, podemos interpretar que Erec, durante o caminho, dizia que manteria sua promessa de todo modo, ou seja, independentemente do que acontecesse.

Todavia, em (17b), expressa uma relação modal com valor semelhante a completamente $^{11}$. Numa leitura atual da ocorrência, teríamos: Toda coisa móvel que homem mandar (...), o que mandar seja obrigado de o dar completamente.

\footnotetext{
${ }^{10}$ Barreto (1999), Rocha (2006) e Houaiss (2001) afirmam que valor semântico originário de todavia é o valor espacial, mas nenhum dos autores apresenta uma ocorrência exemplicativa. No corpus analisado nessa pesquisa também não encontramos nenhum uso com esse valor.

${ }^{11}$ Valor registrado por Barreto (1999).
} 
A ocorrência em (17c) permite uma leitura ambígua tanto como relação de modo com valor de de todo modo quanto como a relação de adversatividade. Numa leitura modal, o valor de todo modo é abstratizado, equivalente a "ainda assim", "seja como for", todavia, nesse caso, veicularia o sentido de que o cavaleiro roga a ida junto a Erec de qualquer modo. Já, numa leitura adversativa, todavia estabelece uma relação de contra-argumentação no sentido de oposição de argumentos, pois embora Erec afirme que não há necessidade de Meraugis ir, esse se oponhe ao argumento de Erec, insistindo na ida.

Em (17d), a relação semântica veiculada por todavia é de adversatividade, uma vez que, no primeiro argumento, o interlocutor conclui que o dinheiro será mandado, mas a conclusão evidenciada pelo segundo argumento é para o sentido oposto - o dinheiro, possivelmente, pode não ser enviado. A conclusão final tende para a ideia defendida no segundo argumento.

$\mathrm{Na}$ ocorrência (17e), representativa do século $\mathrm{XV}$, todavia co-ocorre com o adversativo prototípico mas, reforçando a ideia já defendida por esse ou atuando, principalmente, no nível semântico desse enunciado.

Para contudo, foram identificadas as funções de fórico, conclusivo, ambíguo, adversativo e reforço, como exemplificam as ocorrências em (18).

(18) Funções semânticas de contudo

a. eles mandarom odegradado e nom quiseram que ficasse la cõ eles ./ o qual leuaua huủa bacia pequena e duas ou tres carapuças vermelhas pera dar la ao Sor seo hy ouuese. / nõ curarã de lhes tomar nada e asy o mandaram com tudo. (15CC, Fol4v)

b. Mas o nosso Philosopho Illustre, ate os seus últimos annos, fez o mayor apreço e estimaçam do merecimento, e habilidade de outros, e pagava todo o respeyto a os seus pensamentos. Em huma palavra, o seu modo de proceder em respeyto de si, e de outros era tal, que nem a mais odioza, e malicioza cencura o pôde ja mais offender. E com tudo, que estava armado da mayor humildade que se tem visto, parece estava o Mundo resoluto a lançar tanto peso de louvor, e aplauzo da parte da balança opposta á em que estava a sua grande modestia, que preponderace e fizesse subir as suas eminentes perfeiçoes a hum ponto tam sublime, e levantado, que todos as pudessem ver, e admirar; pois por mais que o defendia a sua modestia, era incessantemente louvado, a plaudido, e admirado em todas 
as Sociedades, e Universidades da Europa em sua Vida... (18TM, p.19)

c. Nem todos se hão de seguir (disse o Doutor) que como escreue o Filosofo Fauorino, cada hum deve vsar de palauras presentes, \& custumes antigos: \& mays quando o vso he abusaõ, que no primeiro, per ser tal, o defenderão as leys: \& no segundo o reprendem os mesmos que o vsão. Com tudo, Leonardo dirá o que lhe parece. (17CA, p.16)

d. Como ficou demonstrado depois, ele nada tinha a ver com o assassinato. A inocência, contudo, não o impediu de ser agredido para confessar a autoria do crime, como agora relatam familiares da vítima. (21FSP, set.03)

e. E aindaque a Escritura sagrada diz, que todos os homens por sua natureza estaõ corruptos pelo peccado, muytos dos Doutores Romanos contendem, que a Virgem Maria foy nascida sem peccado original; e ainda que outros entre elles mesmos contradizem a isto, com tudo todos os da Igreja Romana tem a opiniaõ, que ella foy sem algum peccado actual. (18NA, p.19)

Em (18a), contudo estabelece uma relação fórica, pois retoma o enunciado anterior "o qual leuaua huủa bacia pequena e duas ou tres carapuças vermelhas", ou seja, eles mandaram o degradado com todas as coisas que estavam com ele.

Com tudo, em (18b), é utilizado para estabelecer uma relação de conclusão. No primeiro enunciado, o locutor constrói o seu argumento em defesa do filósofo ilustre, mostrando que ninguém seria capaz de ofendê-lo. O segundo argumento conclui a ideia já apresentada no primeiro argumento, afirmando que as pessoas apenas louvam e aplaudem o tal filósofo.

A partir da interpretação da ocorrência (18c), podemos depreender tanto uma leitura fórica quanto uma leitura adversativa. Numa leitura fórica, teríamos o pronome indefinido tudo retomando todo o enunciado anterior "\& mays quando o vso he abusaõ, que no primeiro, per ser tal, o defenderão as leys: \& no segundo o reprendem os mesmos que o vsão" e, logo após, se afirma que Leonardo dirá o que parece, levando em consideração o que já foi dito. Numa leitura adversativa, por sua vez, temos que a direção argumentativa do primeiro argumento leva o leitor concluir que as possibilidades de resolução do caso já foram apresentadas. No entanto o segundo argumento traz uma informação independente - o dizer do Leonardo sobre o caso - que pode ser considerado como um novo argumento sobre a resolução dos fatos. 
Na ocorrência em (18d), contudo estabelece uma relação adversativa, em que, no primeiro enunciado, o locutor apresenta o argumento que mostra que alguém foi inocentado do assassinato, fazendo o locutor concluir que esse alguém não sofrerá nenhuma represália; no segundo enunciado, no entanto, o argumento defendido é contrário ao primeiro, pois sustenta a ideia de que, mesmo inocente, esse alguém sofreu alguma agressão.

No uso de contudo, em (18e), o item funciona como um reforço, pois a ideia de contrajunção já está estabelecida pelo concessivo ainda que, no enunciado "ainda que outros entre elles mesmos contradizem a isto"; assim, o uso de contudo reforça a direção oposta do argumento introduzido por ainda que.

No entanto realiza apenas quatro das 10 funções mostradas no quadro 06, quais sejam: advérbio temporal, advérbio fórico, adversativo e reforço, como exemplificam as ocorrências em (19). Funções semânticas de no entanto

a. E disse-lhe huu dos filhos, que avia nome Ruben: padre, dá tu a mym Benjamym, e eu o levarei, e se o eu non tornar acá, e o der a ti, toma dous meus filhos, que eu hei, e mataos. E disse Jacob: digo-vos que non hirá meu filho Benjamym comvosco. Entanto despenderom os mantijmentos, e acoitava-os a fame, e disse Jacob a seus filhos: tornade ao Egito, e comprade alguu pouco de mantijmento; e disse-lhe Judas: se tu quiseres emviar cõnosco Benjamym, iremos alá, e em outra guisa non hyremos. (14BMP, p.47)

b. - Tu me profaças de traiçam; mais certamente nom me devem em tanto protaçar como ti; ca se tu nom fôsses mais aleivoso cavaleiro $\|$ ca outro, nom mataras assi tua irmaã por ua sôo palavra que me prometeste. (13DSG, p.20)

c. No 1.0 mês vendemos 60 contos. Cala o bico. Mas eu e o Otales havemos de provar aos povos que somos inderrotáveis. Imaginava que o capital social da grande empresa é só de 50 contos; no entanto as 20.000 gramáticas que vendemos este mês, só elas, nos dão um líquido de 55 contos! (20CE-C, p.19)

d. Este ano é escasso de café, ano de nenhum lucro, mas no entanto tenho um colheitão com o qual espero enterrar os últimos cadáveres. (20CE-C, p.7)

$\mathrm{Na}$ ocorrência (19a), no entanto, grafado como entanto ${ }^{12}$, apresenta uma leitura temporal. Nessa ocorrência, podemos interpretar que Jacob disse a seus filhos para irem ao

\footnotetext{
${ }^{12}$ Cunha (1989) registra a forma de entanto no século XIII como advérbio com significado de "neste meio tempo, neste ínterim, entretanto". Barreto (1999), afirma que entanto é a forma pelo qual origina-se no entanto.
} 
Egito comprar mantimentos enquanto eles despejavam os mantimentos. Como no entanto, entretanto também apresenta valor temporal.

No entanto, em (19b), é um advérbio fórico, com valor de por isso, valor esse que deu origem ao item ${ }^{13}$. Numa interpretação dessa ocorrência, teríamos que o fato de $t u$ ter professado contra o $e u$, não faz com que, por causa disso, o $e u$ professe contra o $t u$.

Em (19c), estabelece-se uma relação semântica adversativa entre os enunciados, pois, no primeiro argumento, a conclusão é direcionada para a ideia de que o lucro da empresa é de 50 contos; no segundo argumento, a conclusão é de que o lucro do mês corrente ultrapassa os 50 contos, atingindo os 55 contos.

A ocorrência (19d) exemplifica o uso de no entanto como reforço adverbial de mas. Podemos considerar que no entanto reforça a conclusão orientada por mas de que, embora tenha a escassez do café, o locutor espera ter um bom lucro.

Do mesmo modo que no entanto, entretanto também realiza apenas três funções: advérbio temporal, advérbio espacial (lugar figurado) e adversativo, como seguem exemplificadas em (20).

(20) Funções semânticas de entretanto

a. Tomada essa resolução se pôs em ordem para este edifício, fazendo primeiro um cercamento forte de pau a pique para os trabalhadores e soldados poderem estar seguros do gentio e como foi acabada arrumou a cidade dela para dentro arruando-a por boa ordem com as casas cobertas de palma ao modo do gentio em as quais por entretanto se agasalharam os mancebos e soldados que vieram na armada e como todos foram agasalhados ordenou de cercar esta cidade de muros de taipa grossa. (16BNB, p.56)

b. Eu sei, que cá- be nos limites da minha Jurisdição | punir esta especie de dezobediencia, e dar por inutil, ede nenh__ efeito alicen | ça concedida; mas hé justo, que esta Ca- | mara, eas futuras conheção quanto dé- vem ser respeitádas, e venerádas as ordens $\mid$ dos senhores Generáes; epor isso oponho | na Prezensa deVossa Excelencia para da | sua parte lho extranhar, com Piedade | sim, mas de forma, que elles conheção agra- | vidade do seo erro, e dasua facilidade, e | que este Padre conheça tamb_, que de- | ve esperar asoberana Decizão, que elle | mesmo prócurou, e entretanto aco- ||| Acomodar se, e não au mentar as | perturbaçoens, partidos e dezunião em | que Vive este Povo: Espero a Rezolução de Vossa Excelencia para saber o que | eide obrar.| (17CBS, p.147)

\footnotetext{
13 Segundo Barreto (1999), o valor explicativo de entanto (no entanto) é registrado como valor original do
} advérbio latino intantum. A autora, em seu trabalho, não encontra usos em português. 
c. Confesso que morreria de vergonha e de ódio se alguém me desse um "ósculo" Entretanto há pessoas que acham um beijo coisa muito vulgar e preferem ósculos. Osculem-se, osculem-se. (20GN, p.121)

Entretanto, em (20a), funciona como um sintagma preposicional que integra a categoria de advérbio espacial (lugar figurado), podendo ser parafraseado por entre tantas coisas, valor originário do item ${ }^{14}$. Ao interpretarmos a ocorrência, temos que os mancebos e soldados foram agasalhados entre tantas coisas.

Na ocorrência (20b), a relação semântica veiculada por entretanto é temporal, podendo ser parafraseada por enquanto isso sucede. Numa leitura atualizada da ocorrência, teríamos: “(...) é justo que esta câmara e as futuras conheçam quanto devem ser respeitadas e veneradas as ordens dos senhores generais, e, por isso, oponho na presença de Vossa Excelência para da sua parte, com piedade, sim, mas de forma que eles conheçam a gravidade dos seus erros e da sua facilidade e que este Padre conheça também que deve esperar a soberana decisão, que ele mesmo procurou, e enquanto isso sucede ele deve se acomodar e não aumentar as perturbações, partidos e desunião em que vive este povo".

Em (20c), temos uma ocorrência exemplificativa da relação adversativa veiculada por entretanto. No primeiro argumento, o locutor admite que ele morreria de vergonha se alguém lhe desse um "ósculo"; no segundo argumento, ressalta, por meio de entretanto, a diferença que há entre ele e pessoas que preferem o ósculo a um beijo.

Grupo 02: posição do item no enunciado início do enunciado meio do enunciado final do enunciado

\footnotetext{
${ }^{14}$ Registrado por Barreto (1999) como valor originário do item.
} 
Por meio do grupo 02, verificamos o percentual apresentado pelos itens estudados quanto à posição ocupada por eles no enunciado. As ocorrências de (21) a (23) exemplificam esse grupo.

(21) Infelizmente, apesar de endurecer as restrições à publicidade, o projeto é vago quanto a uma das facetas mais relevantes do problema. O texto aprovado parece passar ao largo da regulamentação das placas, letreiros e cartazes que identificam a localização das lojas e estabelecimentos comerciais na região. É bem verdade que já há algumas normas para esse tipo de sinalização. Contudo, dada sua profusão na área, seria desejável que o projeto de lei recém-aprovado também contemplasse a questão. (21FSP, mai.05)

Contudo, em (21), ocupa a posição inicial do segundo enunciado, posição prototípica de conjunção. Nessa ocorrência, pode-se dizer que contudo estabelece tanto a relação semântica de adversatividade como a relação sintática de ligar dois enunciados.

(22) O chão, sobre que assenta a certeza de hoje, formou-se pelas alluviões successivas da intuição antiga. O que é sciencia foi já poesia: o sahio foi já cantor: o legislador, poeta: e a evidencia, uma adivinhação, um admiravel palpite, cujas profundas conclusões são ainda o espanto, e porventura o desespero das mais rigorosas philosophias. E, se nadamos hoje em plena luz de razão, foi entretanto a poesia, foi essa doce mão, que nos guiou por entre o pallido crepusculo dos velhos sonhos. (19CAQ, p.22)

Em (22), entretanto ocupa a posição medial do segundo enunciado. Verificaremos, no capítulo IV, se a alta frequência de entretanto ou dos outros itens estudados nessa posição será um dos critérios para afirmar que eles ainda não são conjunções adversativas prototípicas.

(23) O jovem: - Não duvido. Mas é a moda. O impossível é fazemos voltar à clássica ceia em família e com rabanadas, "também chamadas fatias do céu!..." Pode ser que seja mau. Que fazer, porém? (20GN, p.36)

A posição final ocupada por porém, em (23), juntamente com os usos em posição medial, são resquícios da fonte adverbial que admitem mobilidade dos itens na sentença. 
Grupo 03: co-ocorrência com outros juntivos

mas
embora
porém
contudo
todavia
entretanto
no entanto
ainda que
enquanto
/: não se aplica

A partir dos resultados gerados por esse grupo, verificaremos o percentual de uso dos itens estudados com outros juntivos numa mesma sentença. Se apresentar um alto percentual, significa que o item guarda resquício do uso adverbial, afastando-o, assim, do uso conjuncional. Vejamos a ocorrência (24):

(24) Desejo de bem fazer he ja mais special, por que todos teem tal voontade a todos, ainda que o possam bem comprir, e acerca dos chegados o sentem. E porem he já em graao maior e mais estremado. (15LC, p.25)

Nessa ocorrência do século XV, porém co-ocorre com a conjunção aditiva $e$ que pode ser considerada a conjunção coordenativa mais neutra, uma vez que desempenha uma função textual coesiva de dar continuidade ao texto. Acreditamos que, nesse tipo de coocorrência, o primeiro juntivo estabelece a relação sintática da oração, enquanto o segundo estabelece a relação semântica. Analisando a ocorrência (24), constatamos que porém estabelece a ideia de compensação por acréscimo de informação, uma vez que o argumento defendido, no segundo enunciado, é baseado numa informação que acaba por alterar a conclusão do primeiro enunciado, isto é, no primeiro argumento, o falante defende a ideia de que o bem fazer se chega a todos, no segundo argumento, o falante reformula essa 
consideração, afirmando, então, que o bem fazer chega, mas, agora, em grau maior e mais estremado.

Grupo 04: funcionamento semântico-pragmático no uso adversativo ${ }^{15}$ marcador de oposição marcador de negação de inferência marcador de restrição por acréscimo de informação marcador de restrição por refutação marcador de restrição por pedido de informação marcador de compensação por acréscimo de informação marcador de compensação por substituição de informação marcador de compensação por exclusão de informação marcador de surpresa marcador de contra-argumentação marcador de direção independente com acréscimo de novo argumento marcador de direção independente com acréscimo de novo foco marcador de direção independente com acréscimo de novo tema /: não se aplica

Baseados em Neves (1984b) e Longhin-Thomazi (2003), levantamos as possíveis funções que o item adversativo pode vir a assumir. Com os resultados obtidos desse grupo, verificaremos se os itens estão se especializando em determinadas funções.

Neves (1984b) faz um levantamento das manobras argumentativas realizadas por mas e descreve as seguintes manobras: contraposição em direção opostas - com compensação entre $p$ (primeiro enunciado) e $q$ (segundo enunciado); com restrição a $p$ por refutação ou acréscimo de informação ou pedido de informação -; contraposição na mesma direção; contraposição em paralelo - com acréscimo de um novo argumento; com acréscimo de novo foco; com acréscimo de novo tema -; eliminação - sem recolocação; com recolocação.

Longhin-Thomazi (2003), assim como Neves (1984b), também faz um levantamento das estratégias argumentativas de só que, encontrando 5 diferentes funções semânticopragmáticas para o item só que, são essas: marcador de diferença - com adição de

\footnotetext{
${ }^{15}$ No capítulo IV, analisamos as manobras argumentativas estabelecidas pelos itens analisados.
} 
informação; com substituição de informação; exclusão de informação -; marcador de refutação; marcador de surpresa; marcador de contra-argumentação; marcador de nãosatisfação de condições.

A seguir, explicitamos cada uma das manobras argumentativas encontradas para os itens em estudo, seguidas de uma ocorrência exemplificativa. ${ }^{16}$

\section{- marcador de oposição}

A marca de contraste é feita, primeiramente, por meio de palavras com significados opostos ou expressões opostas. Nesse caso, o juntivo adversativo reforça o contraste já estabelecido. Vejamos a ocorrência (25).

(25) A Purtugal foram tragidos Alvoro Gomçallvez e Pero Coelho, e chegarom a Samtarem omde el Rei Dom Pedro era; e el Rei, com prazer de sua viimda porem mal magoado porque Diego Lopez fugira, os sahiu fora a receber... (15CDP, p.57)

Na ocorrência (25), do século XV, o locutor estabelece uma oposição entre a expressão com prazer, apresentando um traço semântico positivo, e a expressão mal magoado, caracterizada por um traço semântico negativo. $\mathrm{O}$ item porém acaba por reforçar essa oposição.

\section{- marcador de negação de inferência}

Nessa função, o juntivo introduz o argumento que nega o argumento anterior, ou seja, o locutor, na primeira oração, admite como argumento o enunciado de outro enunciador $\mathrm{E}_{1}$ (enunciatário) para, no segundo argumento, negar, contestar esse argumento. A ocorrência (26) exemplifica esse uso.

\footnotetext{
16 No próximo capítulo, apresentaremos a frequência type dos juntivos em cada uma das manobras argumentativas.
} 
(26) Aliás tenho mesmo uma memoria muito fraca, razão pela qual preciso duma biblioteca muito grande. Minha memória repousa nas folhas impressas, porém não me lastimo. (20BLA-CRO, p.63)

$\mathrm{Na}$ ocorrência (26), o primeiro argumento faz o interlocutor inferir que o locutor sentia alguma lástima por ter uma memória fraca, mas no segundo argumento o locutor mostra que não sente nenhuma lástima, negando, assim, a inferência feita pelo seu interlocutor.

Segundo Vogt e Ducrot (1980), esse tipo de funcionamento discursivo causa uma polêmica imaginária, em que, ao enunciar não-B se pressupõe a enunciação de $\mathrm{B}$, que é atribuída a um enunciador diferente de $\mathrm{E}_{0}$ (locutor). Equivale a dizer que ao enunciar não-B, necessariamente o locutor enuncia $\mathrm{B}$, fazendo uma oposição a esse. Por essa enunciação $\mathrm{B}$, o locutor não se responsabiliza, apenas a rejeita.

\section{- marcador de restrição}

Esse tipo de marcador é utilizado em contextos que o locutor admite uma conclusão, normalmente um conteúdo pressuposto ${ }^{17}$ ou subentendido, ${ }^{18}$ no primeiro segmento, para depois, sobre ela apresentar alguma restrição, que pode representar: (i) acréscimo de informação, em que o locutor apresenta, no segundo segmento, uma condição para que o fato apresentado no primeiro segmento aconteça; (ii) refutação, em que o locutor refuta, no segundo segmento, algo que tinha sido dito antes; (iii) pedido de informação, em que, no segundo segmento, há questionamento de algum fato presente no primeiro segmento. As ocorrências de (27) a (29) mostram, respectivamente, essas três estratégias argumentativas.

(27) Ca esto todo he per todos dereito determinado, que os que teem oficio de defensores o devem fazer, husando porem de piedado quanto mais poderem ... (15LC, p.12)

\footnotetext{
${ }^{17}$ Entende-se por pressuposto um conteúdo informacional que o locutor pressupõe fazer parte das informações pragmáticas de seu interlocutor, uma informação partilhada, portanto (Dik, 1989).

${ }^{18}$ Por subentendido, entende-se que é tudo aquilo que o locutor deixa para que o seu interlocutor conclua.
} 
(28) Antão ela chego ôtra vêiz, sem brincadêra, e segredô baixinho: "Bamo"? Praque que hei-de falá... mais me deu ua vontade de í cu'ela. Todos tavum reparando e sentí sastifacão. Garrei na cintura dela e fui andano. Minha tenção era chegá nargum lugá sem gente e dá o fóra, porém, você me discurpe, Frorinda, era só tenção, cheguêmo no Colombo. (20BLA-CRO, p.154)

(29) O jovem: - Não duvido. Mas é a moda. O impossível é fazemos voltar à clássica ceia em família e com rabanadas, "também chamadas fatias do céu!..." Pode ser que seja mau. Que fazer, porém? (20BLA-CRO, p.36)

Em (27), a segunda oração "husando porem de piedado quanto mais poderem" restringe a oração "que os que teem oficio de defensores o devem fazer", através de um acréscimo de informação, que, no caso, é uma condição imposta para a realização da oração anterior, isto é, os defensores têm de praticar o seu trabalho, mas dentro da condição imposta. Já em (28), o uso de porém mostra que, embora se tenha afirmado no primeiro segmento que o $e u$ tinha a vontade de chegar em algum lugar sem gente e largar a Frorinda, esse eu, no segundo segmento, refuta essa idéia. Em (29), finalmente, “Que fazer, porém?" é uma interrogativa parcial que não exige uma resposta do interlocutor, mas, sim, apresenta para o interlocutor a indagação do locutor de que não há nada a se fazer.

\section{- marcador de compensação}

Nesse contexto, o locutor estabelece uma relação de comparação de igualdade entre dois elementos. Num primeiro momento, ele expõe as similaridades entre os dois, para, num segundo momento, apresentar a diferença entre eles. A diferença de direção dos argumentos acaba por resultar na compensação.

No corpus, foram encontradas três estratégias de marcação de compensação, a saber: (i) por acréscimo de informação, por meio da qual o locutor pressupõe que o interlocutor tem informação incompleta a respeito de algo e, então, adiciona uma informação necessária para a compreensão; (ii) por substituição de informação, por meio da qual o locutor julga necessário substituir parte de informação por outra; (iii) por exclusão de informação, por meio da qual o 
locutor exclui parte de uma informação que ele julga que seu interlocutor tenha compreendido equivocadamente e não coloca nada no lugar. As ocorrências de (30) a (32) ilustram a marcação de compensação por acréscimo de informação, por substituição de informação e por exclusão de informação, respectivamente.

(30) Nada mais cômico, aliás, que essa mania que tanta gente tem de passar por jornalista. Um homem como o nosso velho e admirável Archymedes Fortini fica aborrecido por ter de fazer esse registro que não dá vantagem de espécie alguma. Um outro cavalheiro, entretanto, que jamais escreveu uma nota de aniversário em um jornal, afoba-se e gasta dinheiro para tirar Diploma de jornalista. (20GN, p.129)

(31) Antre nojo e tristeza eu faço tal defença, por que a tristeza, per qual quer parte que venha, assi embarga sempre continuadamente o coraçom, que nom dá spaço de poder em al bem pensar nem folgar. E o nojo he a tempos, assi como se veee na morte d'alguus parentes e amigos, onde, aquel tempo que per justa falla ou lembrança se sente, o sentimento he muito rijo. Porem taaes hi há que, passado o dia, logo riim, fallam, e despachadamente no que lhes praz sentom. (15LC, p.18)

(32) Mês elegante, jovem, mundano, parlamentar, um tanto Arsênio Lupin de uma grande data, maio - que quer mais V. Ex. para que ele seja um mês perturbador? Se não fossemos todos aliados e boicotastes mesmo em poesia, era o caso de repetir ainda o nosso poeta: o ar é fino, levíssimo. E azul e loiro todo o céu sereno... Maio parece um príncipe germânico das baladas românticas do Reno.

Para mim, porém, riscada a ironia, maio é agradável por outra coisa e só por isso. (20BLACRO, p.60)

Em (30), o locutor introduz a informação "Um outro cavalheiro, entretanto, que jamais escreveu uma nota de aniversário em um jornal, afoba-se e gasta dinheiro para tirar Diploma de jornalista", para enunciar a diferença que há entre Archymedes Fortini e outro homem que nunca escrevera num jornal. Em (31), o locutor primeiramente apresenta uma comparação entre a tristeza e a mágoa, e ao falar da mágoa, julga necessário substituir a informação "o sentimento he muito rijo por "passado o dia, logo riim, fallam, e despachadamente no que lhes praz sentom". Por fim, em (32), o locutor, ao afirmar que a agradabilidade de maio se deve a outra coisa e não à razão dada no primeiro segmento, exclui toda a informação dada - "Mês elegante, jovem, mundano, parlamentar, um tanto Arsênio Lupin de uma grande data, maio - que quer mais V. Ex. para que ele seja um mês 
perturbador?... Maio parece um príncipe germânico das baladas românticas do Reno" - e não a substitui por nada.

\section{- marcador de surpresa}

Como marcador de surpresa, o adversativo introduz um argumento que não era esperado, previsto, desejado, ou seja, aquilo que se esperava não acontece, mas, sim, o que se não esperava. Vejamos a ocorrência (33):

(33) Era uma imprudência, porque tínhamos apenas uns tostões no bolso e não nos lembrávamos de nenhum conhecido na cidade; mas a perspectiva de desembarcar em Santos ou no Rio nos parecia ainda pior. Logo de saída, entretanto, na rua 15 de Novembro, Rubem topou com um amigo providencial, que nos levou para casa e nos deu dinheiro. (20GN, p.143)

Em (33), a partir do enunciado "não nos lembrávamos de nenhum conhecido", o interlocutor conclui que eles não conheciam ninguém naquela cidade; o argumento sustentado por entretanto, a partir de uma transferência metonímica, da expressão usada anteriormente, "logo de saída", traz um fato inesperado pelo locutor - "Rubem topou com um amigo providencial".

\section{- marcador de contra-argumentação}

Alguns usos dos itens adversativos podem ser explicados nos termos da Teoria da Argumentação desenvolvida por Ducrot $(1977,1981)$, em que o autor mostra que, em construções do tipo A mas $\mathrm{B}$, há duas conclusões opostas, sendo o argumento A favorável a conclusão $r$, e o B, argumento mais forte, favorável a não- $r$. Dessa forma, a construção A mas B, como um todo, tende a sua argumentação para a conclusão não-r. Valendo-se das palavras de Ducrot (1981, p.179), "o enunciado A mas B supõe que, no espírito dos interlocutores, existe ao mesmo tempo uma proposição $r$ a qual A é um argumento e $\mathrm{B}$, um contra argumento". 
Koch (1987), dialogando com Anscombre e Ducrot (1982), Vogt e Ducrot (1980), mostra que, por meio de mas, duas ideias são acrescentadas a A e B, sendo: (i) A e B se estabelecem em direções opostas em relação à conclusão $r$, afirmada por $\mathrm{A}$, mas não confirmada por B; (ii) a conclusão não-r, veiculada por B, é mais forte que a de A, fazendo com que o enunciado A mas B seja orientado no sentido de não-r. Vejamos as ocorrências (34) e (35).

(34) É de causar espanto que alguns leitores de um jornal do porte desta Folha de S.Paulo ainda reclamem do fato de que sejam publicados textos como os da sabatina com a escritora e colunista Danuza Leão. Não concordo com quase nada do que ela disse - e, na realidade, tal reportagem nem era muito do meu interesse -, contudo cabe a órgãos como a Folha mostrar a opinião de todos e ser o mais pluralista possível. (21FSP, mar. 06)

Em (34), todo o primeiro argumento "Não concordo com quase nada do que ela (Danuza Leão) disse - e, na realidade, tal reportagem nem era muito do meu interesse" é construído a favor de uma conclusão $r$ - não é necessário publicar a reportagem escrita por Danuza Leão -; o segundo argumento "cabe a órgãos como a Folha mostrar a opinião de todos e ser o mais pluralista possível" descarta essa conclusão $r$ e apresenta uma conclusão contrária, não-r, - a Folha de São Paulo precisa ser pluralista e, por isso, deve publicar a reportagem da Danuza Leão.

(35) Outro dia o Justino, da Revista do Globo, queria que eu respondesse a uma carta em que uma jovem pedia conselhos sentimentais. Tive a honestidade de não responder. Nisso de sentimentos sou confuso e dou amplas mancadas. Nada entendo de amores, de suspiros, dessas coisas assim. Naturalmente eu amo, eu suspiro, eu faço tudo isso que Deus manda, visto que se estamos na terra é mesmo para sofrer. Tenho, porém, uma grande dificuldade em me dirigir nesses assuntos... (20BLA-CRO, p.120)

Em (35), o argumento "Naturalmente eu amo, eu suspiro, eu faço tudo isso que Deus manda, visto que se estamos na terra é mesmo para sofrer" faz com que o interlocutor conclua 
que o locutor tem condições de abordar questões referentes a assuntos sentimentais, porém o argumento "Tenho, porém, uma grande dificuldade em me dirigir nesses assuntos" desconstrói a conclusão anterior, favorecendo, assim, a conclusão do segundo argumento.

\section{- marcador de direção independente}

Como marcador de direção independente, os itens introduzem informação nova, ainda não considerada, mas que acaba sendo mais relevante do que o argumento já admitido. Esse acréscimo pode dar-se de três maneiras: (i) por acréscimo de novo argumento; (ii) por acréscimo de um novo foco ${ }^{19}$; (iii) por acréscimo de um novo tema ${ }^{20}$. As ocorrências de (36) a (38) mostram, respectivamente, essas três estratégias discursivas para marcar a independência de direção.

(36) A verdade é que nenhum país do mundo é constituído apenas por advogados, médicos e engenheiros. Apenas uma elite chega a formar-se nesses cursos. No Brasil, contudo, criou-se a ilusão de que a faculdade abre todas as portas. (21FSP, jan.04)

Em (36), o argumento introduzido por contudo de que, no Brasil, há ilusão de que a faculdade abre todas as portas ainda não havia sido considerado, pois o argumento que estava sendo defendido era que só a elite se forma nos cursos de Direito, Medicina e Engenharia. Esse novo argumento é colocado à consideração para defender a ideia de que a faculdade não é garantia posterior.

(37) Há atrasos em todas as obras. Como não existem nos contratos com concessionários cláusulas de investimento estrutural, é duvidoso que a expansão da rede se materialize, em especial na atual perspectiva sombria da economia mundial. Quando a crise arrefecer, contudo, o país necessitará de infraestrutura para escoar o aumento da produção. Urge, portanto, rever os termos do arrendamento. É preciso encontrar uma fórmula que garanta o investimento para disseminação do transporte ferroviário, preservando ao mesmo tempo a rentabilidade dos concessionários, mas com o compromisso de moderação tarifária. (21FSP, mar. 09)

\footnotetext{
${ }^{19}$ De acordo com Neves (1984b), entendemos foco como foco narrativo que define o centro, na perspectiva do sujeito narrador.

${ }^{20}$ Nos moldes de Bally (1965), tema é o ponto de partida, servindo como suporte para o rema.
} 
O uso de contudo, em (37), faz com que o foco, que, até então, era o atraso das obras devido a inexistência de cláusulas de investimento estrutural, mude para as atitudes que o país precisará tomar quando a crise diminuir. Embora o locutor retome a ideia defendida no foco anterior de que é preciso rever os contratos de investimento estrutural, ele a retoma como uma forma de melhorar a infraestrutura do país para o escoamento.

(38) O regime não mudou sob FHC, mas o sistema de governo sofreu importantes adaptações. Mesmo sem reforma radical no organograma, definiram-se campos de atuação para os quais convergiram as agendas de vários ministérios. Porém entre as principais questões deixadas em aberto pelo governo FHC estão a reforma das universidades federais e a modernização dos órgãos de financiamento, basicamente a Capes e o CNPq. (21FSP, dez. 02)

Em (38), no primeiro argumento "Mesmo sem reforma radical no organograma, definiram-se campos de atuação para os quais convergiram as agendas de vários ministérios", a temática abordada é os campos de atuação dos ministérios. Já, no segundo argumento, a unidade temática é a reforma das universidades federais e a modernização dos órgãos. Como se nota, o acréscimo do segundo argumento não implica, necessariamente, a desconsideração do primeiro.

Essas funções semântico-pragmáticas apresentadas não são discretas, uma vez que uma mesma ocorrência pode se enquadrar em mais de uma função. Essa não-discretude é reflexo da relação de contraste por quebra de expectativa, característica invariável, presente em todos os enunciados articulados pelos juntivos adversativos. A variabilidade ocorre a partir dos diferentes contextos em que esses itens ocorrem, os quais revelam diferentes estratégias discursivas, tais como: oposição, negação de inferência, restrição, compensação, surpresa, contra-argumentação e direção independente, e, possivelmente, ainda outras não detectadas no corpus.

Segundo Longhin-Thomazi (2003), há um esquema básico, identificável em todas as ocorrências de "só que", que poderíamos estender para as ocorrências dos itens aqui 
estudados, isto é, o cancelamento de pressuposição comum aos participantes da interação. Para tratar dessa questão da pressuposição comum, ela retoma Stalnaker (1972), que afirma: "pressupor uma proposição no sentido pragmático é aceitar como certa sua verdade e supor que os outros envolvidos no contexto façam o mesmo (STALNAKER, 1972; p. 390; grifo nosso).

Essa suposição a que Stalnaker se refere é menos uma suposição e mais uma imposição, um efeito da linguagem, ou seja, o locutor, ao empregar o operador, "joga o jogo da linguagem", como se essa suposição fosse mesmo legítima, isto é, obtida a partir do uso do operador. Em outras palavras, o emprego do operador cria um contexto pragmático no qual a pressuposição é legítima, pois antes de seu emprego não tem nada que garantia que essa informação fosse mesmo disponível a ambos os participantes da interação.

Grupo 05: nível de articulação sintática

Sentenças ou porções textuais independentes

sentenças ou porções textuais dependentes

termos

modificadores

Baseados no trabalho de Pezatti e Longhin-Thomazi (2008), verificamos quais são os níveis de articulação em que os itens atuam. As autoras, ao trabalhar com as conjunções mas e só que, mostram que essas conjunções articulam sentenças independentes, sentenças dependentes, termos e modificadores. A partir dessas análises de mas e só que, observarmos se porém, contudo, todavia, entretanto e no entanto atendem a todos esses níveis apresentados. As ocorrências de (39) a (42) exemplificam esse níveis:

A articulação de sentenças ou porções textuais independentes é feita por meio da justaposição ou é explicitada por algum conector, como mostra a ocorrência em (39). 
(39) A mobilização corporativista, além de revolta, plantou também a dúvida na alma de todos: qual seria a confiabilidade desse serviço de segurança quando policiais não seguem o que eles próprios chamam de padrão? Parece óbvio que em uma das duas situações acabem por não cumprir integralmente sua obrigação. A liderança paredista deve um esclarecimento ao público. Fica dispensada, porém, da franqueza acintosa com que o presidente do sindicato da PF em São Paulo admitiu que as filas servem para "chamar a atenção do governo". (21FSP, abr.07)

Em (39), a oração "Fica dispensada, porém, da franqueza acintosa com que o presidente do sindicato da PF em São Paulo admitiu que as filas servem para "chamar a atenção do governo" é independente sintaticamente da oração anterior. De acordo com a hipótese que estamos defendendo, a relação sintática entre as duas orações é feita por meio de justaposição e a relação semântica estabelecida pelo juntivo porém.

A articulação de sentenças ou porções textuais dependentes ocorre quando o item articula enunciados que ocorrem como sentença encaixada a um predicado matriz. Essa articulação pode ser feita tanto por justaposição quanto por coordenação explícita. Vejamos a ocorrência (40).

(40) Eu pensei:

1' - Que a ação do rapaz em defesa do pai era nobre.

2' - Que era demasiada - pois não se separa uma briga de taponas à faca.

3 - Que, entretanto, sendo o rapaz impulsivo e filho de carniceiro, a herança e o hábito deviam tê-lo obrigado a tomar da faca mais facilmente que de um pau. (20GN, p.82)

Na ocorrência (40), a oração "Que, entretanto, sendo o rapaz impulsivo e filho de carniceiro, a herança e o hábito deviam tê-lo obrigado a tomar da faca mais facilmente que de um pau." é uma sentença encaixada a uma oração matriz e desempenha a função de subordinada substantiva objetiva direta. A relação sintática é estabelecida por meio da conjunção integrante que e entretanto estabelece a relação semântica de adversatividade. 
A articulação de termos ocorre quando um constituinte da sentença é multiplicado, como, por exemplo, a coordenação de sintagmas nominais ou entre sintagmas preposicionados, como exemplificado em (41).

(41) Não duvido que a ideologia democrática tenha tido o seu valor, mas hoje, diante das exigências do tempo, nem se sabe mais o que é. É um mito. duma largueza aquosa, tão adaptável ao PC (1) como ao PRP. O resultado disso é que o voto secreto não conseguiu que adiantássemos um passo sobre 1930. Não se discutiu ideologias, ninguém se dedicou por sistemas, porém por indivíduos. (20GN, p.180)

O juntivo porém, em (42), estabelece a coordenação entre dois termos, mais especificamente, entre dois sintagmas preposicionados - "ninguém se dedicou por sistemas, porém por indivíduos".

A articulação de modificadores ocorre quando se articulam dois sintagmas adjetivais, como mostra a ocorrência exemplificativa em (43).

(43) Estes livros propriamente naõ pertencem á Escritura sagrada, nem foraõ escritos, como os Livros Canonicos, pela inspiração divina. Poloque tambem Christo e os Evangelistas e Apostolos, que tantas vezes citáraõ livros ou textos do Velho Testamento, nunca citão a estes ou a seus textos. Mas sendo estes Livros Apocryphos com tudo bons e proveitosos para lér, e dando elles também algum lume na historia daquelle tempo, os guardamos como outros bons livros, e lhes damos sua estima por causa da edificação que daõ, e por causa de sua antiguidade. (18NA, p.17)

Em (43), com tudo estabelece a coordenação entre os sintagmas adjetivais Apocryphos e bons e proveitosos para ler.

Nesse trabalho, consideramos como justaposição os casos previstos nas gramáticas tradicionais e os casos em que os itens ocorrem em posição medial e final de enunciado, não havendo nenhum conectivo na posição inicial para estabelecer o elo sintático entre as orações. Nesses casos, acreditamos que o item em posição medial ou final de enunciado está apenas 
desenvolvendo a relação semântica entre as duas orações, não articulando-as, assim, no nível sintático. Vejamos a ocorrência exemplificativa (44).

(44) Em termos ideais, um político nunca precisaria ter de explicar-se para a população. O mundo real, porém, como todos sabemos, nada tem de ideal. (21FSP, nov.03)

Nessa ocorrência, porém ocupa posição medial no segundo enunciado e desempenha a relação de adversatividade entre os enunciados "Em termos ideais, um político nunca precisaria ter de explicar-se para a população." e "O mundo real como todos sabemos, nada tem de ideal". O vínculo sintático que há entre esses dois enunciados é estabelecido por meio da justaposição.

Grupo 06: presença de negação

primeira oração

segunda oração

nas duas orações

Barreto (1999), baseada em Said Ali (1964), afirma que uma das hipóteses para aquisição do valor adversativo pelos itens porém, contudo, todavia, entretanto e no entanto é o contexto em que esses itens eram empregados em sentenças negativas ou em sentenças afirmativas precedidas por sentenças negativas. Sendo assim, verificamos se essa hipótese apresenta um percentual significativo no corpus, influenciando, via metonímia, a mudança semântica dos itens. Observemos as ocorrências de (45) a (47):

(45) Apparecerão oppositores a estas cadeiras; mas como ainda pendem de decisão do Governo Imperial as duvidas que vos referio meu antecessor acerca do provimento d'ellas, nada se tem podido fazer. Entretanto espero que serão attendidas as instantes rogativas que acabo de dirigir ao Governo Imperial, para que tenhão prompta solução essas duvidas. (19DMA, p.5)

(46) - Dom Erec, disse Meraugis, eu vos ouí ora dizer que érades aqui antre vosso enmigos, e vós sodes melhor cavaleiro ca eu; mais todavia vos digo que, se aqui fazer quiserdes algua rem de armas, que por [seerem] muitos nom o leixedes, ca eu vos tenho por tam boõ cavaleiro que, por pouca de ajuda que vos eu farei, nom nos empecerã, se i nom fôr grã pôboo sobejo. (13DSG, 
p.11)

(47) Como ficou demonstrado depois, ele nada tinha a ver com o assassinato. A inocência, contudo, não o impediu de ser agredido para confessar a autoria do crime, como agora relatam familiares da vítima. (21FSP, set03)

Como se observa, nas ocorrências acima, há a presença de um elemento de negação. Em (45), o item não estabelece a negação na primeira oração, enquanto, em (46), o item nom contribui para a negação da segunda oração. Em (47), há a presença da negação nas duas orações, a negação da primeira oração direciona o argumento para a conclusão - o sujeito acusado não cometeu um assassinato e, por isso, não confessará o crime -, já a negação da segunda oração que recai sobre o SV altera a direção do argumento dessa oração - o sujeito acusado, embora não tenha cometido o crime, foi agredido com objetivo de fazer com que ele confessasse.

Grupo 07: tipo de negação

explícita

implícita

Considerando a hipótese de Barreto (1999), investigamos qual a relevância do nível de explicitação da negação, ou seja, investigamos se o tipo de negação tem alguma relevância para o processo de mudança semântica dos adversativos, via metonímia.

A negação explícita ocorre por meio de vocábulos como não, nunca, nem, nenhuma e outros, e a implícita, por meio de prefixos ou termos negativos. As ocorrências de (47) e (48) exemplificam os fatores desse grupo.

(48) Acabo de ler o artigo "Carta aberta ao senador Eduardo Suplicy", em que Plínio de Arruda Sampaio defende os atos praticados recentemente pelo MST no Rio Grande do Sul. Suas colocações a respeito dos malefícios da monocultura são parcialmente corretas, uma vez que, de fato, a monocultura, se levada ao extremo, compromete mesmo a biodiversidade. Cabe porém lembrar que a monocultura não se restringe a eucaliptos ou pinheiros, mas também à cana, à soja, ao café e à laranja, para ficar em alguns exemplos. (21FSP, mar.06) 
Em (48), como se observa, a negação é explicitada pelo advérbio não, presente na segunda oração.

(49) E aindaque a Escritura sagrada diz, que todos os homens por sua natureza estaõ corruptos pelo peccado, muytos dos Doutores Romanos contendem, que a Virgem Maria foy nascida sem peccado original; e ainda que outros entre elles mesmos contradizem a isto, com tudo todos os da Igreja Romana tem a opiniaõ,que ella foy sem algum peccado actual. (18NA, p.19)

Nessa ocorrência (49), a negação do primeiro enunciado é dada implicitamente, por

meio do valor semântico negativo de contradizem.

Grupo 08: correlação modo-temporal entre as orações

Presente do Indicativo + Presente do Indicativo

Pretérito imperfeito do Indicativo + Pretérito imperfeito do Indicativo

Pretérito mais que perfeito do Indicativo + Pretérito imperfeito do Indicativo

Pretérito perfeito do Indicativo + Pretérito imperfeito do Indicativo

Pretérito perfeito do Indicativo + Pretérito perfeito do Indicativo

Pretérito imperfeito do Indicativo + Futuro do pretérito do Indicativo

Presente do Indicativo + Futuro do presente do Indicativo

Presente do Indicativo + Pretérito imperfeito do Indicativo

Pretérito Imperfeito do Indicativo + Futuro do presente do Indicativo

Pretérito Imperfeito do Indicativo + Pretérito Perfeito do Indicativo

Presente do Subjuntivo + Presente do Subjuntivo

Pretérito imperfeito do Indicativo + Presente do Indicativo

Presente do Indicativo + Pretérito perfeito do Indicativo

Presente do Subjuntivo + Presente do Indicativo

Presente do Indicativo + Futuro do pretérito do Indicativo

Futuro do presente do Indicativo + Presente do Indicativo

Pretérito imperfeito do Indicativo + Gerúndio

Pretérito imperfeito do Indicativo + Pretérito imperfeito do Subjuntivo

Futuro do presente do Indicativo + Futuro do presente do Indicativo

Particípio + Presente do Subjuntivo

Pretérito perfeito do Indicativo + Presente do Indicativo

Pretérito imperfeito do Subjuntivo + Pretérito imperfeito do Subjuntivo

Gerúndio + Gerúndio

Futuro do pretérito do Indicativo + Pretérito perfeito do Indicativo

Presente do Indicativo + Gerúndio

Futuro do pretérito do Indicativo + Presente do Indicativo

Presente do Subjuntivo + Infinito Pessoal

Futuro do Subjuntivo + Futuro do presente do Indicativo

Futuro do Subjuntivo + Imperativo

Presente do Indicativo + Pretérito imperfeito do Subjuntivo 
Futuro do pretérito do Indicativo + Futuro do pretérito do Indicativo Pretérito perfeito do Indicativo + Futuro do presente do Indicativo Pretérito perfeito do Indicativo + Futuro do pretérito do Indicativo Pretérito perfeito do Indicativo + Infinitivo

Presente do Indicativo + Pretérito mais que perfeito do Indicativo

Gerúndio + Imperativo

Presente do Indicativo + Infinitivo

Pretérito perfeito do Indicativo + Gerúndio

Pretérito perfeito do Indicativo + Pretérito imperfeito do Subjuntivo

Pretérito mais que perfeito do Indicativo + Presente do Indicativo

Pretérito imperfeito do Subjuntivo + Presente do Indicativo

Futuro do presente do Indicativo + Futuro do Subjuntivo

Pretérito imperfeito do Indicativo + Infinitivo Pessoal

Presente do Subjuntivo + Gerúndio

Pretérito perfeito do Indicativo + Presente do Subjuntivo

Futuro do presente do Indicativo + Infinitivo Pessoal

Presente do Indicativo + Presente do Subjuntivo

Pretérito mais que perfeito do Indicativo + Pretérito perfeito do Indicativo

Futuro do pretérito + Presente do Subjuntivo

Infinitivo Pessoal + Pretérito imperfeito do Indicativo

Pretérito imperfeito do Subjuntivo + Pretérito imperfeito do Indicativo

Presente do Subjuntivo + Imperativo

Pretérito imperfeito do Indicativo + Presente do Subjuntivo

Pretérito imperfeito do Subjuntivo + Pretérito Imperfeito do Indicativo

Futuro do pretérito do Indicativo + Pretérito imperfeito do Indicativo

Futuro do pretérito do Indicativo + Futuro do presente do Indicativo

Futuro do Subjuntivo + Presente do Subjuntivo

Pretérito imperfeito do Indicativo + Pretérito mais que perfeito do Indicativo

Imperativo + Pretérito perfeito do Indicativo

Infinitivo Pessoal + Imperativo

Pretérito imperfeito do Subjuntivo + Futuro do pretérito do Indicativo

Imperativo + Imperativo

/: não se aplica $^{21}$

Nesse grupo, a partir do levantamento de todas as correlações modo-temporais dos enunciados, observamos se os itens investigados tendem a ser empregados com uma determinada correlação modo-temporal.

Grupo 09: possibilidade de paráfrase por mas

$\operatorname{sim}$

não

${ }^{21}$ Estamos considerando casos de não se aplica quando não há, realmente, uma correlação modo-temporal porque um dos verbos foi suprimido, ou, quando os itens articulam porções maiores de textos, não conseguindo, assim, depreender quais verbos estabelecem correlação. 
Com esse grupo, verificamos se os itens estudados, em uso prototípico de conjunção, permitem ser parafraseados pela conjunção adversativa prototípica mas. Vejamos ocorrências exemplificativas em (49) e (50).

(49) Infelizmente, apesar de endurecer as restrições à publicidade, o projeto é vago quanto a uma das facetas mais relevantes do problema. O texto aprovado parece passar ao largo da regulamentação das placas, letreiros e cartazes que identificam a localização das lojas e estabelecimentos comerciais na região. É bem verdade que já há algumas normas para esse tipo de sinalização. Contudo, dada sua profusão na área, seria desejável que o projeto de lei recém-aprovado também contemplasse a questão. (21FSP, mai.05)

(49’) Infelizmente, apesar de endurecer as restrições à publicidade, o projeto é vago quanto a uma das facetas mais relevantes do problema. O texto aprovado parece passar ao largo da regulamentação das placas, letreiros e cartazes que identificam a localização das lojas e estabelecimentos comerciais na região. É bem verdade que já há algumas normas para esse tipo de sinalização. Mas, dada sua profusão na área, seria desejável que o projeto de lei recém-aprovado também contemplasse a questão. (21FSP, mai.05)

Como observa-se, em (49), contudo estabelece uma relação semântica de adversatividade, ocupa posição inicial de oração, apresentando, assim, características de conjunção adversativa prototípica. Por esse motivo, é possível contudo ser parafraseado por mas, como acontece em (49’).

(50) Não se pode negar que o Banco Central vem procurando ampliar suas operações no mercado de câmbio com vistas a conter a forte valorização do real. Os resultados, porém, têm sido pouco expressivos. (21FSP, fev.05)

(50') Não se pode negar que o Banco Central vem procurando ampliar suas operações no mercado de câmbio com vistas a conter a forte valorização do real. Os resultados, *mas, têm sido pouco expressivos. (21FSP, fev.05)

Em (51), porém ocupa posição medial no segundo enunciado e, por isso, causa um estranhamento ao substituí-lo por mas que não aceita essa posição. 
Grupo 10: sincronia

$\begin{array}{lll}\text { XIII } & \text { XVI } & \text { XIX } \\ \text { XIV } & \text { XVII } & \text { XX } \\ \text { XV } & \text { XVIII } & \text { XXI }\end{array}$

A partir dos resultados apresentados por esse grupo de fator, verificamos a frequência com que os itens ocorreram em cada sincronia e estabelecemos possíveis cruzamentos desse com outros grupos de fator.

Da correlação encontrada entre esses grupos de fatores, esperamos chegar a uma classificação dos juntivos que permita estabelecer diferentes graus de gramaticalidade entre eles, de modo a refletir suas próprias evoluções diacrônicas. Assim esperamos que a confluência de fatores de alguns grupos possa nos fornecer traços identificadores de usos identificados com as categorias de advérbio, advérbio juntivo ou conjunção. Abaixo, no quadro 7, apresentamos os grupos com os respectivos fatores que podem nos fazer chegar a essa classificação.

\begin{tabular}{|l|l|l|l|}
\hline \multicolumn{1}{|c|}{ categoria $^{22}$} & ADVÉRBIO & ADVÉRBIO JUNTIVO & CONJUNÇÃO \\
\hline grupo de fatores & $\begin{array}{l}\text { Tempo, Modo, } \\
\text { Lugar, Fórico, } \\
\text { Reforço }\end{array}$ & $\begin{array}{l}\text { Ambígua, Conclusiva, } \\
\text { Adversativa }\end{array}$ & Conclusiva, Adversativa \\
\hline Posição & $\begin{array}{l}\text { Inicial, Medial, } \\
\text { Final }\end{array}$ & Medial, Final & Inicial \\
\hline Co-ocorrência & Sim & Sim & Não \\
\hline Nível de articulação & Não se aplica & $\begin{array}{l}\text { Sentença independente, } \\
\text { Sentença dependente, } \\
\text { Modificadores }\end{array}$ & Sentença independente \\
\hline $\begin{array}{l}\text { Possibilidade } \\
\text { paráfrase por } \text { mas }\end{array}$ & Ne & Não & Sim \\
\hline Exemplos & $(51)$ & $(52)$ & (53) \\
\hline
\end{tabular}

QUADRO 07: Fatores identificadores de usos adverbiais e conjuncionais dos itens a serem pesquisados

${ }^{22}$ Os grupos de fatores 4, 6, 7, 8 e 10 não são determinantes para a classificação do item em uma dessas categorias. 
Dessa confluência de traços, consideramos como advérbio, usos com funções semânticas espaciais, temporais, fóricas ou modais, tendo como escopo alguns elementos do texto ou porções maiores do enunciado.

Outra função adverbial refere-se aos casos em que esses itens funcionam como reforço de outro juntivo de mesma natureza semântica com o qual co-ocorre. Quanto ao uso como reforço, há uma discussão na literatura se o primeiro conector atuaria apenas no nível sintático, enquanto o segundo, no nível semântico. Fraser (2006) afirma que, embora essa temática seja carente de investigação, o primeiro conector é por ele considerado marcador discursivo primário, que seria um item principal, básico das quatro classes de marcadores discursivos - contrastivos (mas), elaborativos (e), inferenciais (por que) e temporais (então) e o segundo conector é um membro de uma dessa classes. Os itens que analisamos são considerados advérbios juntivos em contextos em que eles desempenham apenas uma função semântica, marcando a relação de sentido que se estabelece entre dois enunciados justapostos ou articulados por outros tipos de juntivos.

Por fim, como de uso conjuncional, são consideradas ocorrências em que o item funciona como uma conjunção adversativa prototípica, ou seja, os itens articulam a sentença tanto no nível sintático como no nível semântico e, também, não co-ocorrem com outro juntivo.

As ocorrências de (51) a (53) exemplificam cada uma das categorias apresentadas no quadro 7.

(51) Per. Ora avendo os Bispos de Roma deste modo alcançado o que buscavaõ, que cousa faziaõ elles despois nos tempos seguintes? Rep. Elles começavaõ a governar manifestamente a Igreja Christaõ, chamando-se a si mesmos Cabeças da Igreja, e a introduzir de vagar desd'a aquelle tempo todas suas falsas doutrinas e superstiçoens mudando e corrompendo a doutrina Christaõ conforme seu interesse mundano. E sendo passado algum tempo despois de averem estabelecido este seu governo de antichristo, elles naõ mais mostravaõ o devido respeito nem a os Emperadores mesmos, mas avendo elles por muyta semrezaõ e traiçaõ alcançado grandes 
terras em Italia; e deste modo acquirido para si todo o poder sobre a Igreja de Europa, juntamente com muyta alteza mundana, elles refusavaõ ser por diante sugeitos com seus Clerigos a o Governo secular, e alevantavaõ-se com tam excessiva soberba atè sobre os Emperadores, e todos os outros Christaõs Potentados de Europa, que elles se atrevèraõ de dàrlhes, ou de tirar-lhes o imperio, de obrigar a os Emperadores a tomar a coroa de sua maõ, postos de joelhos, e de dar-lhes às vezes no tempo da coroaçaõ couces tambem. Fora disso os Papas de Roma puzèraõ muytas vezes inteiras Cidades, Terras Reys e Emperadores em grave interdito, pelas mais injustas excommunhoens; e sua soberba era tam grande, que elles offereciaõ seus pès a serem beijados dos Principes e Grandes, e que elles punhaõ em sua cabeça hua tresdobrada coroa. E por sua horrivel crueldade elles perseguiaõ com fogo e espada a todos quantos naõ queriaõ obedecer a suas falsas doutrinas. Com toda tal excessiva soberba e horrenda crueldade elles se fizèrão adorar, e temer, como a deuses. 2. Thes. 2, v. 3. 4.

6. Perg. Mas com tudo isto, porventura todas as Igrejas Christaõs no mundo tem conhecido a o Papa de Roma por sua Cabeça? (18TM, p.4)

Em (51), contudo atende as seguintes características de advérbio: funciona como advérbio de reforço, pois reforça a ideia de adversatividade já estabelecida por mas; ocupa posição medial; co-ocorre com outro juntivo, no presente caso o mas, e não permite paráfrase por mas.

(52) Não se pode negar que o Banco Central vem procurando ampliar suas operações no mercado de câmbio com vistas a conter a forte valorização do real. Os resultados, porém, têm sido pouco expressivos. (21FSP, fev.05)

A ocorrência (52) de porém se enquadra nas características de advérbio juntivo, pois o item estabelece relação semântica de adversatividade, ocupa posição medial, articula sentenças independentes e não permite paráfrase por mas.

(53) Na ânsia da valorização tudo é improvisado, fingido, disfarçado fregolianamente". Iludir, seja lá como for - eis o ideal.

Contudo, ainda não desapareceram da tela da vida deste vasto cinematógrafo de povos que é São Paulo uns tipos interessantes, com certas tintinhas de bizarrice, que tiveram sua origem no seio da casta tradicional de fazendeiros. (20GN, p.194) 
Nessa ocorrência, contudo é classificado como uma conjunção adversativa, pois estabelece relação semântica de adversatividade, ocupa posição inicial, não co-ocorre com outro juntivo, articula sentenças independentes e permite a paráfrase por mas. 


\section{CAPÍTULO IV}

\section{A GRAMATICALIZAÇÃO DOS JUNTIVOS ADVERSATIVOS PORÉM, CONTUDO, TODAVIA, ENTRETANTO E NO ENTANTO}

Nesse capítulo, apresentamos análises do comportamento sintático, semântico e pragmático dos juntivos porém, contudo, todavia, entretanto e no entanto, ao longo dos séculos XIII a XXI, levando em consideração os critérios apresentados e discutidos no capítulo anterior. Primeiramente, fazemos a exposição dos resultados alcançados para cada um dos juntivos, a fim de oferecer uma visão do processo de mudança de cada um deles. Num segundo momento, procederemos a uma análise comparativa do comportamento diacrônico dos juntivos, com o propósito de estabelecer uma escala de gramaticalidade entre eles.

\subsection{Apresentação geral}

Os juntivos adversativos porém, contudo, todavia, entretanto e no entanto apresentam frequências tokens diferentes e oscilantes. Trata-se de dizer, em outras palavras, que, devido a influências linguísticas ou extralinguísticas, esses itens apresentam, durantes os séculos investigados, oscilação em suas frequências, ora bastante alta, ora extremamente baixa, chegando a zero em determinada sincronia.

Na tabela 01 abaixo, encontra-se o total de ocorrências de todos os itens investigados, do século XIII ao XXI. 


\begin{tabular}{|c|c|c|c|c|c|c|}
\hline Século & Porém & Todavia & No entanto & Contudo & Entretanto & Total \\
\hline XIII & 43 & 7 & 1 & 0 & 0 & 51 \\
\hline XIV & 73 & 2 & 2 & 1 & 0 & 78 \\
\hline $\mathbf{X V}$ & 109 & 6 & 0 & 2 & 0 & 117 \\
\hline XVI & 33 & 11 & 0 & 8 & 1 & 53 \\
\hline XVII & 35 & 2 & 0 & 14 & 4 & 55 \\
\hline XVIII & 45 & 2 & 0 & 12 & 0 & 59 \\
\hline XIX & 53 & 18 & 0 & 0 & 17 & 88 \\
\hline $\mathbf{X X}$ & 74 & 2 & 6 & 2 & 37 & 121 \\
\hline XXI & 28 & 4 & 20 & 17 & 11 & 80 \\
\hline Total & 493 & 54 & 29 & 56 & 70 & 702 \\
\hline
\end{tabular}

Tabela 01: Frequência geral dos itens de XIII a XXI

Como se observa, na tabela 1, porém é o juntivo de uso mais frequente, se comparado aos demais juntivos, tanto no total de todos os séculos quanto em cada uma das sincronias. Os outros juntivos apresentam certas oscilações que podem estar associadas a diversos fatores linguísticos e extralinguísticos, tais como tipo e gênero textual, grau de formalidade dos textos, entre outros.

No século XXI, os diferentes juntivos apresentam frequência token mais equilibrada, sobretudo em razão da diminuição da frequência de porém e entretanto e do aumento de contudo, todavia e no entanto, em relação ao século XX. A conjunção coordenativa adversativa prototípica mas, que serve de controle nesse trabalho por meio do grupo de fator 09, apresenta alta frequência token em todas as sincronias, fato que, entre outros, como os já apontados acima, pode justificar também a baixa frequência das suas formas concorrentes. Diante das frequências tokens, observa-se que os juntivos adversativos sempre foram de uso menos frequente, se comparados ao uso de mas. ${ }^{1}$

Outro fato a observar é que, nos corpora investigados, as formas porém, todavia e no entanto são reconhecidas já no século XIII, seguidas de contudo, no século XIV, e entretanto,

\footnotetext{
${ }^{1}$ Ao menos nas sincronias mais atuais, é seguro afirmar que o uso preferencial de mas, nos textos investigados, em detrimento dos demais juntivos, deve-se, segundo informação de profissional da área de jornalismo, ao seu menor número de caracteres: enquanto mas tem apenas 3 caracteres, os outros podem chegar a até 10.
} 
mais tardiamente, no século XVI. Como detalharemos nas seções dedicadas a cada um desses itens, nem sempre esse período de emergência coincide com a datação dada pelos dicionaristas. Outro ponto a ser abordado mais detidamente, ainda nesse capítulo, diz respeito à emergência não somente da forma, mas do valor adversativo e do estatuto categorial de conjunção dos itens.

No gráfico 1, apresentamos a frequência token dos itens investigados por século, a fim de melhor visualizarmos a convivência deles numa mesma sincronia.

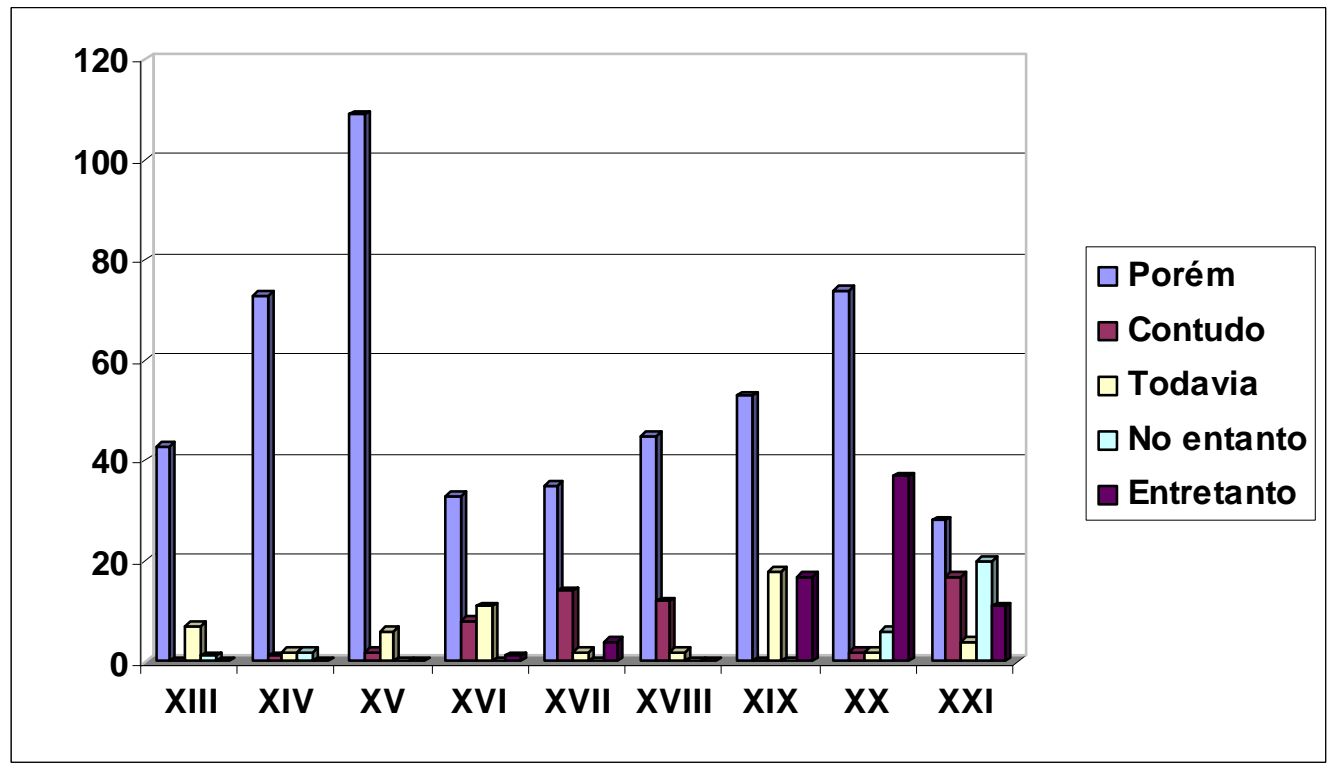

Gráfico 01: A frequência token dos itens por século

Como se observa, porém é usado frequentemente desde o século XIII, enquanto os demais vão surgindo no decorrer dos séculos. A partir do século XX, estabelece-se a convivência de todos os itens, que se torna, no século XXI, um tanto mais harmônica, em termos de frequência de uso, com exceção de todavia.

A análise mais detalhada das frequências token e type de cada item nos permitirá mostrar a mudança que ocorre, na história da língua portuguesa, no domínio funcional dos adversativos, verificando quais fatores linguísticos explicam a mudança e o comportamento sintático, semântico e pragmático desses itens nas diferentes sincronias. 


\subsection{A gramaticalização dos advérbios juntivos adversativos}

\subsubsection{Contudo}

O advérbio juntivo contudo, segundo Houaiss (2001), tem o seu primeiro registro reconhecido no século XIV sob a forma contodo, coincidindo com o que foi encontrado. Esse item se formou a partir da justaposição da preposição com ao pronome indefinido tudo, do latim totu, que, segundo Barreto (1999), significava "a totalidade de pessoas, animais ou coisas". O sentido original desse item é com todas essas/as coisas.

Nos textos investigados, encontramos as seguintes grafias: cõ tudo, com tudo, comtudo e contudo. A aglutinação da preposição com o pronome indefinido, no nível da escrita, aconteceu entre o século XVIII e XX, de acordo com o que encontramos nos corpora.

No gráfico 2, mostramos o comportamento da frequência token de contudo desde o século XIV até o XXI.

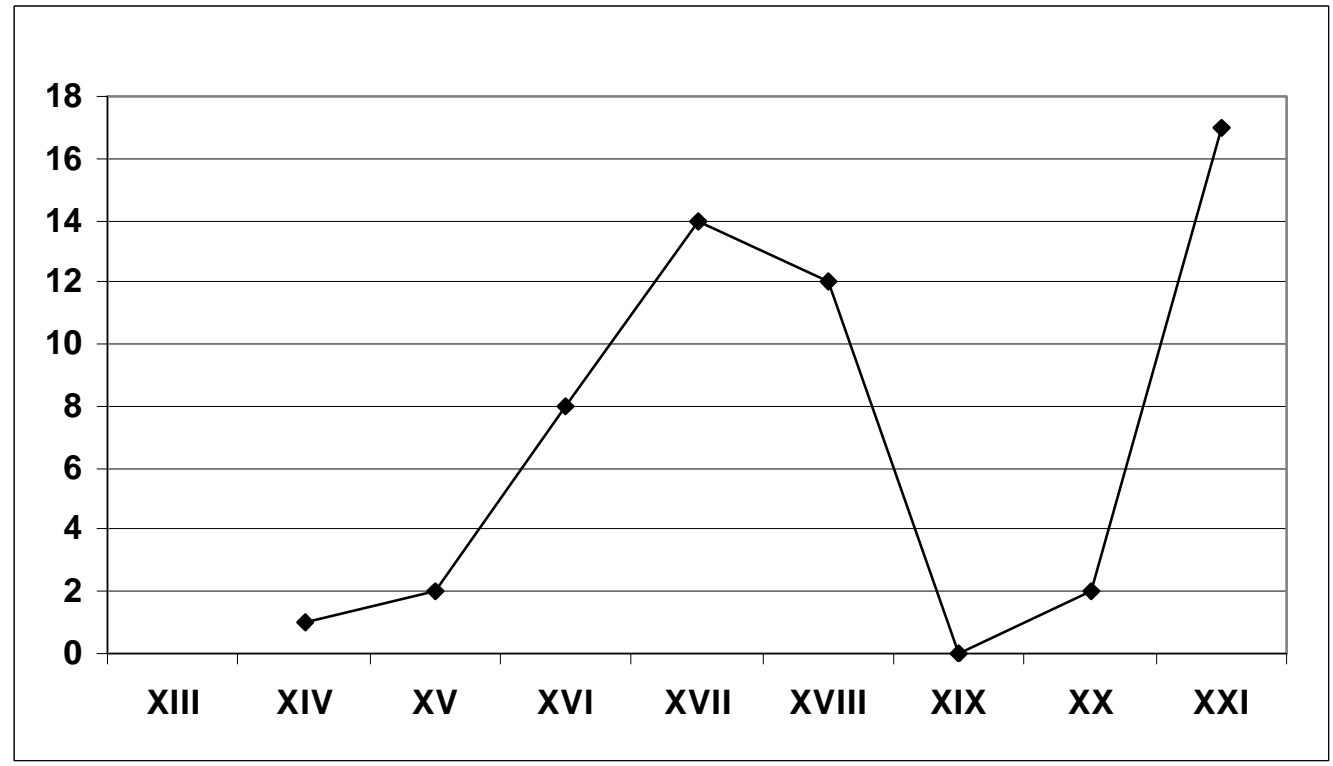

Gráfico 02: Frequência token de contudo do século XIV a XXI 
Observamos que contudo tem sua frequência aumentada durante os séculos de XV a XVII , a qual diminui nos séculos XVIII, chegando a nulidade no século XIX, e aumentando, novamente, nos séculos XX e XXI. A falta de ocorrências no século XIX pode estar relacionada a diversos fatores, tais como: tipo e gênero textual dos textos investigados, estilo do autor, uso de outros juntivos que expressem a mesma relação semântica, entre outros.

Na tabela 2, expomos as frequências token e type de contudo na totalidade dos séculos investigados.

\begin{tabular}{|c|c|c|c|}
\hline Frequência & \multicolumn{3}{|c|}{ Frequência type } \\
\hline \multirow[t]{8}{*}{56} & \multicolumn{3}{|c|}{05} \\
\hline & Categoria & Valor semântico & Totais \\
\hline & \multirow{2}{*}{$\begin{array}{l}\text { Conjunção } \\
(28,6 \%)\end{array}$} & $\begin{array}{ll}\text { Ambígua: } & \text { fórico } \\
\text { /adversativo } & \end{array}$ & $\begin{array}{c}5 \\
(8,9 \%)\end{array}$ \\
\hline & & Adversativa & $\begin{array}{c}11 \\
(19,7 \%)\end{array}$ \\
\hline & $\begin{array}{l}\text { Advérbio } \\
\text { juntivo } \\
(57,1 \%)\end{array}$ & Adversativo & $\begin{array}{c}32 \\
(57,1 \%)\end{array}$ \\
\hline & \multirow{2}{*}{$\begin{array}{l}\text { Advérbio } \\
(14,3 \%)\end{array}$} & Fórico & $\begin{array}{c}6 \\
(10,7 \%)\end{array}$ \\
\hline & & Reforço & $\begin{array}{c}2 \\
(3,6 \%)\end{array}$ \\
\hline & & Total & $56(100 \%)$ \\
\hline
\end{tabular}

Tabela 02: Frequência token e type totais de contudo na história do português (séc. XIV a XXI)

Como exposto na tabela acima, contudo apresenta um total de 56 ocorrências ao longo dos séculos investigados, as quais se distribuem em 3 types sintáticos - advérbio, 14,3\%, advérbio juntivo, 57,1\%, e conjunção, 28,6\%. Quanto às relações semânticas desempenhadas por contudo, observamos que um mesmo tipo semântico pode aparecer em mais de uma categoria sintática. O tipo fórico, sentido original do item, ocorre apenas na categoria advérbio como 10,7\%; o tipo reforço ocorre em 3,6\% dos dados; o tipo adversativo 
ocorre como advérbio juntivo, com 57,1\%, e como conjunção, com 19,7\%; o tipo que configura a relação ambígua entre fórico/adversativo ocorre como conjunção em $8,9 \%$ dos dados.

Como se nota, contudo ocorre predominantemente como advérbio juntivo com valor adversativo, type no qual se concentra metade das ocorrências levantadas. Esse uso afasta-se do uso puramente adverbial, cujos valores semânticos, juntos (14,3\%), também se distanciam do uso conjuncional adversativo, o segundo mais frequente $(19,7 \%)$. Diante dessa constatação, pode-se verificar uma mudança categorial em curso em favor da junção, como veremos logo mais.

De (54) a (60), seguem ocorrências exemplificativas de cada um dos types sintáticosemânticos considerados na tabela 2 .

\section{(54) Sintagma preposicionado como advérbio de valor fórico}

eles mandarom odegradado e nom quiseram que ficasse la cõ eles ./ oqual leuaua huũa bacia pequena e duas ou tres carapuças vermelhas pera dar la ao $S^{\text {or }}$ seo hy ouuese. / nõ curarã de lhes tomar nada e asy omandaram com tudo. (15CC, Fol. 4v)

Em (54), o item contudo é considerado um advérbio que estabelece uma relação anafórica, uma vez que ele retoma o enunciado "huũa bacia pequena e duas ou tres carapuças vermelhas.”. Esse valor fórico, proveniente do pronome indefinido tudo, é considerado original e, como veremos no gráfico 05 , ocorre até o século XVIII.

Vejamos agora em (55) o funcionamento de contudo como advérbio de reforço.

\section{(55) Sintagma preposicionado como advérbio de reforço}

E aindaque a Escritura sagrada diz, que todos os homens por sua natureza estaõ corruptos pelo peccado, muytos dos Doutores Romanos contendem, que a Virgem Maria foy nascida sem peccado original; e ainda que outros entre elles mesmos contradizem a isto, com tudo todos os da Igreja Romana tem a opiniaõ, que ella foy sem algum peccado actual. (18NA, p.19) 
Como se nota, em (55), contudo reforça a ideia de oposição estabelecida por ainda que em "ainda que outros entre elles mesmos contradizem a isto". Segundo Câmara (1975) e Castilho (2004), esse contexto de co-ocorrência com outro juntor que estabelece oposição contribuiu para que contudo adquirisse, metonimicamente, o valor de contrajunção.

Exemplifiquemos, de (56) a (58), o valor juntivo adversativo de contudo.

\section{Advérbio juntivo adversativo}

(56) Essa he hua das razões, porque eu os reprouo (tornou o Doutor:) porque a fabula he hua cousa falsa, que podia com tudo ser verdadeira, \& acontecer assim como se fingio. (17CA, p.6)

(57) 5. Dizem-me que será maravilha poder lá chegar, porque sam acabados os nordestes e sam já entrados os suduestes que an-de durar seis meses, e contudo assi como estou me embarcarei , segundo me mandarão recado, oje ou amenhã, porque além de mo ter já escripto o P. Manuel da Nobrega, depois que arribei chegarão a este porto dois navios, que de Sam Vicente partirão em diversos dias, e em ambos me escreve que en toda maneira vaa, e assi ee necessario pera elle vir à Baia, como V. R. escreve. (16CPJ, p.30)

(58) Tinha um talento tal que suas obras poderiam facilmente figurar em museus, não no caráter de imitações, mas como legítimos originais. Isto envolvia um problema, contudo. Seria bem possível que ladrões -talvez seus companheiros, talvez ele próprio, num momento tresloucado- roubassem os seus quadros. (21FSP, jun.08)

O juntivo contudo, em (56), ocorre em posição medial e estabelece, apenas, a relação semântica de adversatividade, por meio da oposição semântica entre as palavras falsa e verdadeira, enquanto a relação sintática é feita por subordinação a oração anterior.

Em (57), contudo também ocorre em posição medial e estabelece uma relação de adversatividade entre as duas orações, uma vez que o primeiro enunciado traz o argumento de que será maravilhoso chegar em determinado local, pois os sudoestes estão entrados, e o segundo argumento acrescenta um novo argumento, mostrando que, para o locutor, esse fato não é importante, e ele embarcará como está. Nessa ocorrência, a relação sintática é estabelecida pelo conector aditivo $e$. 
O uso de contudo e dos demais itens com o conector $e$ é altamente frequente entre os séculos XIII e XVIII. Acreditamos que esse uso é recorrente, pois e pode ser considerado um elemento neutro e responsável pelo desenvolvimento textual, coesivo, enquanto o outro conector contudo, todavia, porém, entretanto e no entanto seja responsável pela aspecto semântico-pragmático do enunciado.

O uso de contudo em posição final aparece em duas ocorrências apenas em todo o corpus. Em (58), o item articula apenas o nível semântico das orações que ligam, expressando uma relação de adversatividade. Na primeira oração, o locutor admite que determinadas obras de um pintor deveriam figurar em museus como originais e, na segunda oração, por meio de contudo, ele apresenta um restrição a esse comentário - ladrões ou o próprio autor roubaria os quadros.

Em (59), apresentamos uso ambíguo de contudo entre leitura de valor fórico e de valor adversativo.

\section{(59) Conjunção ambígua entre fórico/adversativo}

Nem todos se hão de seguir (disse o Doutor) que como escreue o Filosofo Fauorino, cada hum deve vsar de palauras presentes, \& custumes antigos: \& mays quando o vso he abusaõ, que no primeiro, per ser tal, o defenderão as leys: \& no segundo o reprendem os mesmos que o vsão. Com tudo, Leonardo dirá o que lhe parece. (17CA, p.16)

Nessa ocorrência, contudo ocupa posição inicial e permite tanto uma leitura fórica quanto uma leitura adversativa. Numa leitura fórica, o pronome indefinido tudo retoma anaforicamente o enunciado anterior " $\&$ mays quando o vso he abusaõ, que no primeiro, per ser tal, o defenderão as leys: \& no segundo o reprendem os mesmos que o vsão", para depois afirmar que Leonardo dirá o que parece, levando em consideração o que já foi dito. Já, numa leitura adversativa, a direção argumentativa do primeiro argumento leva o leitor para a 
conclusão de que a opinião de Leonardo não será precisa, no entanto o segundo argumento traz uma afirmação contrária a isso, isto é, Leonardo dirá o que lhe parece.

Segue, em (60), ocorrência exemplificativa do uso conjuncional de contudo.

\section{(60) Conjunção adversativa}

Em os Livros Propheticos muytos textos saõ de todos os mais difficeis por entender, comprehendendo cousas por muyta parte ainda naõ cumpridas; com tudo Deus quer, que sejaõ, lidos, e mais e mais esquadrinhados, dando benignas promessas a os diligentes leitores, como vemos Apocal. 1, 3. (18NA, p.15)

Na ocorrência (60), contudo apresenta características de uma conjunção prototípica. Trata-se de dizer, em outras palavras, que contudo está ocupando posição inicial da segunda oração e não está co-ocorrendo com outros conectores. A relação de adversatividade é estabelecida entre o argumento os livros proféticos são difíceis de entender e o argumento Deus quer que sejam lidos, o argumento apresentado por contudo acaba prevalecendo sobre o outro.

Na tabela 3, apresentamos o percentual de ocorrências em cada uma das posições sintáticas - inicial, medial e final - ocupadas por contudo.

\begin{tabular}{|c|c|c|}
\hline \multicolumn{2}{|c|}{ Posição/categoria } & Percentual \\
\hline \multirow[t]{3}{*}{ Inicial } & Advérbio & $\begin{array}{c}3 \\
(5,4 \%)\end{array}$ \\
\hline & $\begin{array}{l}\text { Advérbio } \\
\text { juntivo }\end{array}$ & $\begin{array}{c}1 \\
(1,8 \%)\end{array}$ \\
\hline & Conjunção & $\begin{array}{c}16 \\
(28,6 \%) \\
\end{array}$ \\
\hline \multirow[t]{2}{*}{ Medial } & Advérbio & $\begin{array}{c}4 \\
(7,1 \%) \\
\end{array}$ \\
\hline & $\begin{array}{l}\text { Advérbio } \\
\text { juntivo }\end{array}$ & $\begin{array}{c}30 \\
(53,6 \%) \\
\end{array}$ \\
\hline \multirow[t]{2}{*}{ Final } & Advérbio & $\begin{array}{c}1 \\
(1,8 \%) \\
\end{array}$ \\
\hline & $\begin{array}{l}\text { Advérbio } \\
\text { juntivo }\end{array}$ & $\begin{array}{c}1 \\
(1,8 \%)\end{array}$ \\
\hline & Total & $\begin{array}{c}56 \\
(100 \%) \\
\end{array}$ \\
\hline
\end{tabular}

Tabela 03: Frequência das posições sintáticas de contudo na história do português (séc. XIV a XXI) 
Diante das frequências apresentadas na tabela acima, constatamos que 53,6\% das ocorrências de contudo assumem a posição medial como advérbio juntivo. A partir desses resultados, podemos concluir que contudo, embora guarde resquícios de sua fonte adverbial, está se aproximando da posição inicial, típica das conjunções prototípicas. Uma análise minuciosa dessa constatação pode ser feita por recurso ao cruzamento dos fatores categoria e século, como se observa no gráfico 3.

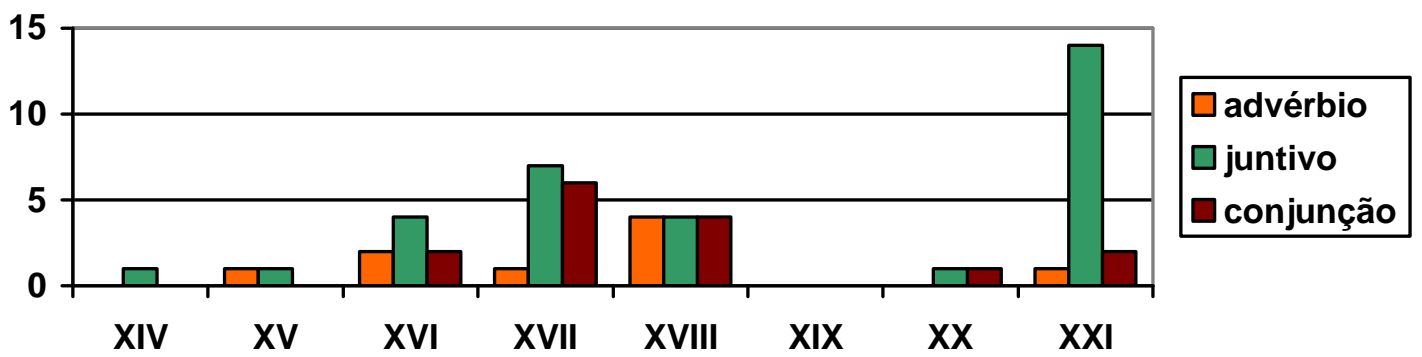

Gráfico 03: O desenvolvimento categorial de contudo do século XIV ao XXI

Pelo gráfico acima, vê-se que a categoria advérbio juntivo está presente em todas as sincronias em que contudo aparece. A categoria advérbio, considerada a categoria-base, ocorre a partir do século XV, mas isso não nos permite afirmar que não haja ocorrência de contudo como advérbio no século XIV. A categoria conjunção, por fim, ocorre desde o século XVI, mas sempre em frequência menor que a de advérbio juntivo ou equiparada com ele, como acontece no século XVIII e XX. No século atual, o uso de contudo como advérbio juntivo é ainda predominante, o que reforçaria a nossa hipótese de que esse item ainda não integra totalmente a classe das conjunções. Uma análise minuciosa dos fatores que favoreceram a mudança do item juntamente com a análise comparativa de contudo com os demais juntivos nos permitirá afirmar qual foi a trajetória de mudança categorial do item. Por ora, uma possível escala de gramaticalização de contudo seria a dada abaixo. 
Quanto ao aspecto semântico de contudo, foram encontrados, como já mostrado na tabela 02, cinco types: (i) fórico, (ii) conclusivo, (iii) ambíguo entre fórico e adversativo ou entre conclusivo e adversativo, (iv) reforço de um item contrastivo e (v) adversativo. No gráfico 4, apresentamos o comportamento semântico de contudo nos séculos investigados.

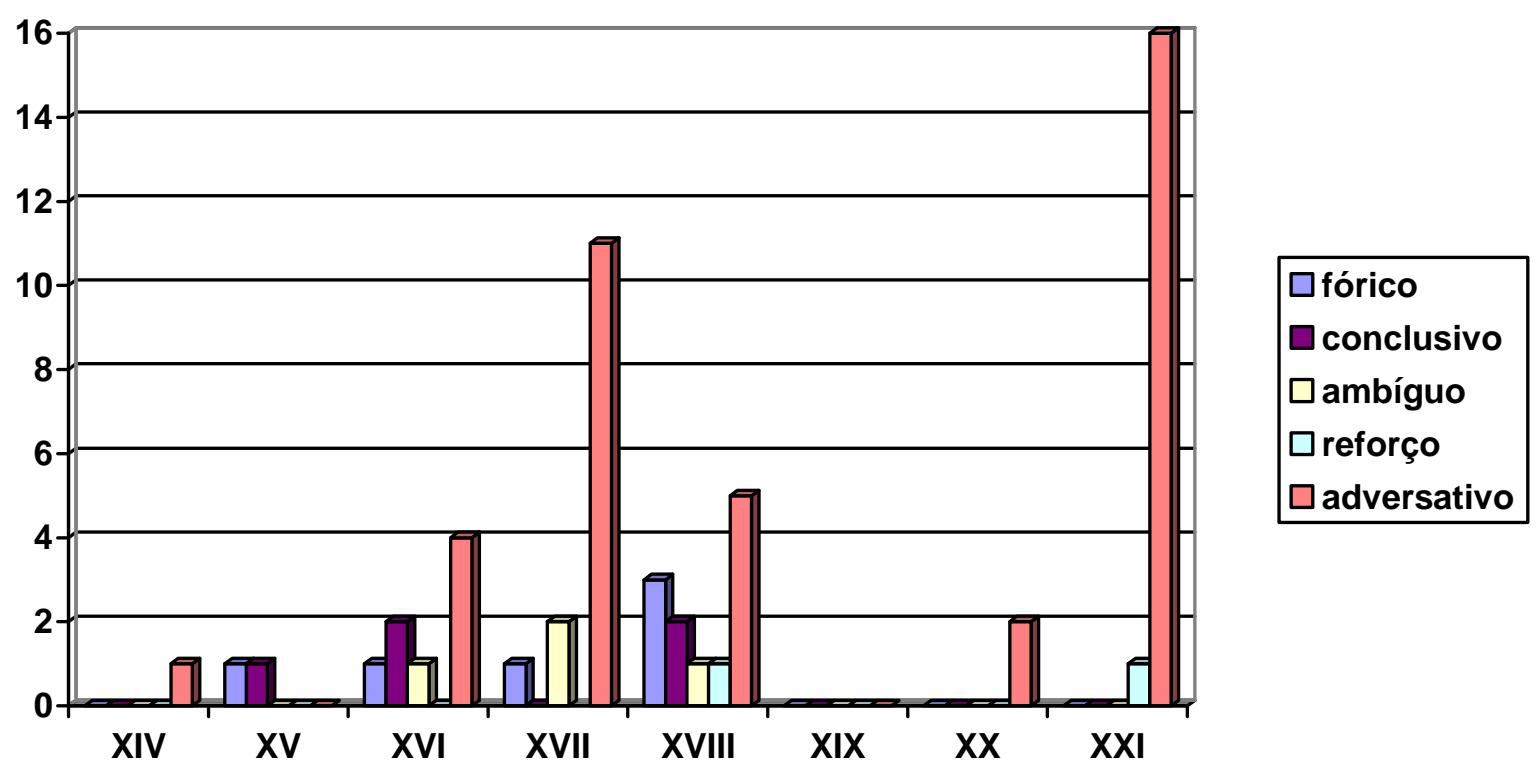

Gráfico 04: Os valores semânticos de contudo do século XIV ao XXI.

O valor adversativo, característico da categoria mais gramaticalizada, ocorre a partir do século XIV, não apresentando ocorrências no século XV. Essa falta de ocorrências com valor adversativo no século XV e com valor original de fórico no século XIV não apresenta problema para análise, uma vez que o valor adversativo ocorre predominantemente em todos os demais séculos em que contudo ocorre, e o valor fórico apresenta ocorrências até o século XVIII. Entre os séculos XVI e XVIII, constata-se o convívio dos diferentes valores semânticos veiculados por contudo. O uso fórico e o conclusivo podem ser considerados como estágio inicial da mudança, uma vez que o valor coesivo presente no pronome indefinido tudo está presente nos dois usos. Segundo Rocha (2006), o pronome tudo se utiliza 
dos mecanismos da coesão anafórica para retomar informações apresentadas anteriormente, dando o sentido de com todas as/essas coisas. A partir desse sentido referencial, o uso adversativo se estabelece, pois o locutor precisa retomar o que já tinha sido dito para estabelecer a relação contrajuntiva.

Os usos ambíguos - fórico/adversativo e conclusivo/adversativo - e de reforço de outro item contrastivo são considerados estágios intermediários para a completa fixação do valor adversativo.

O uso de contudo como reforço adverbial adversativo seria um dos contextos que teria favorecido seu processo de mudança semântica rumo ao valor adversativo (Said Ali, 1964). Nos dados, entretanto, não é o que se verifica, uma vez que o reforço adverbial, além de baixa frequência, ocorre apenas no século XVIII e XXI. Essa constatação leva a duas especulações que serão investigadas em momento posterior: (i) a primeira, a de refutação da hipótese de Said Ali (1964); (ii) a segunda, a de a não ocorrência nos demais séculos ser uma limitação do corpus.

Uma possível escala de mudança das funções semânticas seria:

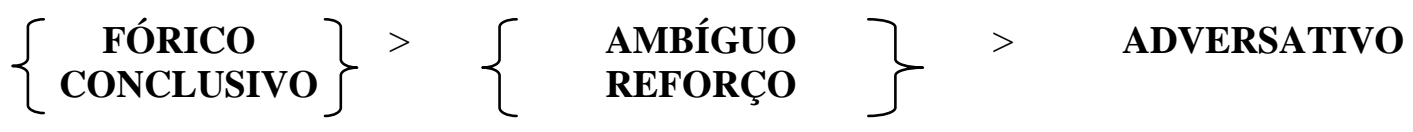

Segundo Barreto (1999), a fixação do uso adversativo dos itens aqui estudados é resultado de uma mudança, via metonímia, devido à alta frequência desses em contextos negativos. De acordo com o controle da presença da negação, os resultados são os expressos na tabela 04 . 


\begin{tabular}{|c|c|}
\hline Contexto Negativo & Frequência \\
\hline Negação na primeira oração & $14(50 \%)$ \\
\hline Negação na segunda oração & $13(46.4 \%)$ \\
\hline Negação nas duas orações & $1 \quad(3.6 \%)$ \\
\hline Total & $28(100 \%)$ \\
\hline
\end{tabular}

Tabela 04: O uso de contudo em presença de elemento de negação ao longo da história do português (séc. XIV a XXI)

Como se observa, das 56 ocorrências de contudo, 50\% apresentam contextos negativos, que se distribuem em três tipos: negação na primeira oração (50\%), negação na segunda oração $(46,4 \%)$ e negação nas duas orações $(3,6 \%)$. Diante desses percentuais, podemos afirmar que o contexto negativo constitui fator favorável à instauração do valor adversativo de contudo, corroborando a hipótese de Said Ali (1964) e de Barreto (1999). Vejamos a ocorrência (63), exemplificativa desse contexto.

(63) Aindaque S. Pedro era pobre, de tal modo que dizia: Prata e ouro naõ tenho, Act. 3, 6. com tudo não tinha cobiça alguma de cousas terreaes (18NA, p.11)

A relação de contrajunção é estabelecida no nível epistêmico e não no nível do conteúdo, pois não há nada de contraste entre o fato do locutor não ter prata e ouro e não ter cobiça alguma de coisas terrestres. $O$ contraste se estabelece entre a inferência que o interlocutor pode fazer a partir do enunciado Prata e ouro não tenho de que o locutor, embora não tenha prata e ouro, tenha cobiça e a informação do segundo enunciado que o locutor não tem cobiça.

Relativamente aos usos adversativos, controlamos as diferentes estratégias argumentativas empregadas quando contudo expressa sentido adversativo. Os resultados seguem na tabela 5 , abaixo. ${ }^{2}$

\footnotetext{
${ }^{2}$ Ocorrências exemplificativas de todas as estratégias argumentativas se encontram no capítulo III. Por questão de economia, optamos por não repeti-las aqui.
} 


\begin{tabular}{|c|c|c|c|c|c|c|c|c|c|}
\hline Estratégias argumentativas & XN & $\mathbf{X V}$ & $\mathbf{X M}$ & XYI & XYII & $\mathbf{X X}$ & $\mathbf{X X}$ & $\mathbf{X X I}$ & Total \\
\hline contra-argumentação & 1 & - & 3 & 7 & 3 & - & - & 6 & $\begin{array}{c}20 \\
(45,4 \%) \\
\end{array}$ \\
\hline $\begin{array}{l}\text { direção independente (acréscimo } \\
\text { de novo argumento) }\end{array}$ & - & - & 2 & 1 & - & - & - & 2 & $\begin{array}{c}5 \\
(11,4 \%) \\
\end{array}$ \\
\hline oposição & - & - & - & 2 & 1 & - & - & 1 & $\begin{array}{c}4 \\
(9,1 \%)\end{array}$ \\
\hline $\begin{array}{l}\text { direção independente (acréscimo } \\
\text { de novo foco) }\end{array}$ & - & - & - & 2 & - & - & 1 & 3 & $\begin{array}{c}6 \\
(13,6 \%)\end{array}$ \\
\hline negação de inferência & - & - & - & 1 & 1 & - & - & 2 & $\begin{array}{c}4 \\
(9,1 \%)\end{array}$ \\
\hline $\begin{array}{l}\text { restrição } \\
\text { (refutação) }\end{array}$ & - & - & - & - & 1 & - & - & - & $\begin{array}{c}1 \\
(2,3 \%)\end{array}$ \\
\hline $\begin{array}{l}\text { direção independente (acréscimo } \\
\text { de novo tema) }\end{array}$ & - & - & - & - & - & - & 1 & - & $\begin{array}{c}1 \\
(2,3 \%)\end{array}$ \\
\hline $\begin{array}{l}\text { restrição } \\
\text { (pedido de informação) }\end{array}$ & - & - & - & - & - & - & - & 2 & $\begin{array}{c}2 \\
(4,5 \%)\end{array}$ \\
\hline $\begin{array}{l}\text { restrição } \\
\text { (acréscimo de informação) }\end{array}$ & - & - & - & - & - & - & - & 1 & $\begin{array}{c}1 \\
(2,3 \%)\end{array}$ \\
\hline Frequência token & 1 & - & 5 & 13 & 6 & - & 2 & 17 & $\begin{array}{c}44 \\
(100 \%)\end{array}$ \\
\hline Frequência type & 1 & - & 2 & 5 & 4 & - & 2 & 7 & 10 \\
\hline
\end{tabular}

Tabela 05: Estratégias argumentativas de contudo (adversativo) do século XIV ao XXI

Como se observa, a estratégia argumentativa mais frequente, no percentual geral, é a de contra-argumentação, em que o locutor apresenta, no segundo enunciado, um argumento que vai em direção oposta à afirmação feita no primeiro enunciado. A análise das estratégias argumentativas por século nos permitiu observar que o uso de diferentes tipos de estratégias se reflete na frequência token, confirmando a hipótese defendida por Bybee (2003) de que o aumento da frequência token surge com um resultado do aumento dos números e tipos de contextos. Logo no século XXI, século em que contudo apresenta o maior número de tokens, temos sete diferentes estratégias utilizadas.

Abaixo segue uma ocorrência exemplificativa da estratégia de contra-argumentação, a mais recorrente no corpus.

(64) É pouco provável, porém, que esse seja o caso de Bush, cujo favoritismo para a disputa eleitoral do ano que vem só tende a se fortalecer com as boas perspectivas de retomada econômica. O Iraque, contudo, deverá permanecer como um flanco aberto na campanha, 
especialmente se vidas continuarem sendo perdidas, como ocorreu ontem, com a derrubada de um helicóptero que matou mais de uma dezena de militares. (21FSP, nov.03)

Em (64), a relação de contra-argumentação é estabelecida entre a conclusão do primeiro enunciado - o favoritismo de Bush tende a crescer - e a conclusão do segundo enunciado - a guerra do Iraque diminuirá o favoritismo de Bush. Essa relação de contraste se dá no nível epistêmico, pois do fato de Bush ter o favoristimo conclui-se que ele ganhará as eleições. Isso entra em conflito com a informação implícita de que Bush poderá perder as eleições, se a guerra do Iraque continuar.

\subsubsection{Todavia}

Segundo Houaiss (1991), todavia, datado do século XIII, foi formado, no latim, da junção do pronome indefinido tota com o sintagma nominal via, com sentido de em todo o caminho. No português arcaico, passou a integrar a classe dos advérbios, com o sentido originário de sempre, constantemente. Nos textos investigados, além da grafia corrente, já presente nos textos do século XIII, ocorre também a grafia mais próxima da forma original tota via.

No gráfico 5, apresentamos a frequência token de todavia no período dos séculos XIII a XXI. 


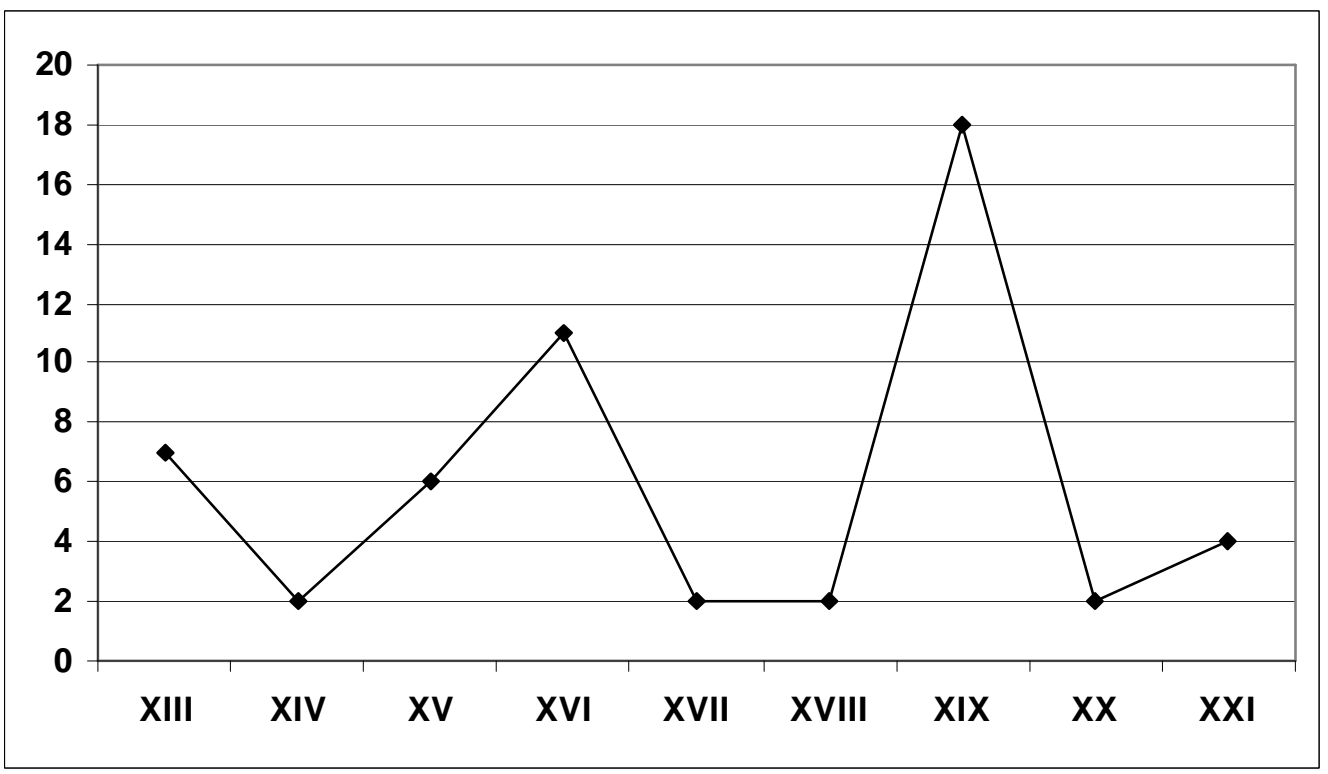

Gráfico 05: Frequência token de todavia do século XIII ao XXI

Embora todavia apresente uma frequência oscilante nos textos investigados, ocorre em todas as sincronias investigadas. A frequência token de todavia aumenta do século XIV ao XVI, mantém-se estável nos séculos XVII e XVIII e alcança seu maior pico no século XIX; no século XX, o item chega à nulidade; no século XXI, ele apresenta poucas ocorrências, devido ao tipo de texto jornalístico.

Na tabela 6, à página seguinte, expomos as frequências token e type de todavia durante os séculos investigados.

Numa análise geral, constatamos que, enquanto o uso conjuncional apresenta uma frequência baixa, 16,7\%, o uso adverbial, estágio inicial do processo de gramaticalização, apresenta uma frequência alta, 42,6\%. Enquanto categoria de nível intermediário, o uso como advérbio juntivo apresenta frequência de 40,7\%, valor não muito distante do uso puramente adverbial, mas muito distante, ambos, do uso mais gramaticalizado como conjunção (16,7\%). Em termos frequenciais, esses resultados para todavia podem diagnosticar um processo de gramaticalização lento ou tardio na história da língua. 


\begin{tabular}{|c|c|c|c|}
\hline Frequência & \multicolumn{3}{|c|}{ Frequência type } \\
\hline 54 & \multicolumn{3}{|c|}{06} \\
\hline & Categoria & Valor semântico & Totais \\
\hline & \multirow[t]{2}{*}{$\begin{array}{l}\text { Conjunção } \\
(16,7 \%)\end{array}$} & $\begin{array}{l}\text { Ambígua: de todo modo, constantemente/ } \\
\text { adversativo }\end{array}$ & $\begin{array}{c}1 \\
(1,9 \%)\end{array}$ \\
\hline & & Adversativa & $\begin{array}{c}8 \\
(14,8 \%) \\
\end{array}$ \\
\hline & \multirow{2}{*}{$\begin{array}{l}\text { Advérbio } \\
\text { juntivo } \\
(40,7 \%)\end{array}$} & $\begin{array}{l}\text { Ambígua: de todo modo, constantemente/ } \\
\text { adversativo }\end{array}$ & $\begin{array}{c}1 \\
(1,9 \%)\end{array}$ \\
\hline & & Adversativo & $\begin{array}{c}21 \\
(38,8 \%) \\
\end{array}$ \\
\hline & \multirow[t]{3}{*}{$\begin{array}{l}\text { Advérbio } \\
(42,6 \%)\end{array}$} & $\begin{array}{l}\text { Advérbio de modo I (de todo modo; } \\
\text { constantemente) }\end{array}$ & $\begin{array}{c}19 \\
(35,2 \%) \\
\end{array}$ \\
\hline & & Advérbio de modo II (completamente) & $\begin{array}{c}2 \\
(3,7 \%) \\
\end{array}$ \\
\hline & & Reforço & $\begin{array}{c}2 \\
(3,7 \%)\end{array}$ \\
\hline & & Total & $\begin{array}{c}54 \\
(100 \%)\end{array}$ \\
\hline
\end{tabular}

Tabela 06: Frequência token e type totais de todavia na história do português (séc. XIII a XXI)

Ainda sob esse panorama mais geral, que considera os resultados de todos os séculos conjuntamente, o valor semântico que se sobressai no uso de todavia é o de adversativo (53,6\%), tanto na categoria de advérbio juntivo como na de conjunção.

Essas informações gerais sobre o comportamento categorial e semântico de todavia, ou seja, de sua alta frequência como advérbio e como adversativo, podem levar a hipotetizar que sua mudança semântica é anterior à categorial. Entretanto, apenas uma análise que considera o comportamento sintático-semântico do item nas diferentes sincronias permitirá confirmar ou refutar essa hipótese, como se verá mais adiante. Por ora, vejamos nas ocorrências de (65) a (72), ocorrências exemplificativas de cada um dos types considerados na tabela 6 . 


\section{(65) Advérbio de modo I}

ca ham de vijr em esta terra do Egito sete anos de grande avondança, e depos eles outros sete anos de grande falecimento, e de grãa fame per toda a terra do Egito, em tal guisa que esquecerá toda a avondança, que ante ouve, e esto demostram as sete vacas grossas, e as sete spigas compridas; e porque o sonho foi dobrado, e visto per duas vezes demostra afirmamento de verdade, que todavia assi ha de seer como demostram os sonhos. (14BMP, p.45)

Em (65), todavia é considerado um advérbio que estabelece uma relação modal que pode ser parafraseada por "de todo modo", ou seja, o sonho visto duas vezes demonstra a constatação da verdade que de todo modo assim há de ser como demonstram os sonhos. Nenhuma leitura de adversidade é possível de ser apreendida nesse contexto, do mesmo modo que também não é possível na ocorrência em (66).

\section{(66) Advérbio de modo II}

No meio das cahoticas leituras a que então me entregava, devorando com egual voracidade romances e livros de sciencias naturaes, poetas e publicistas e até theologos, a leitura do Fausto de Goethe (na traducção franceza de Blaze de Bury) e o livro de Rémusat sobre a nova philosophia allemã exerceram todavia sobre o meu espirito uma impressão profunda e duradoura: fiquei definitivamente conquistado para o Germanismo; e, se entre os francezes, preferi a todos Proudhon e Michelet, foi sem duvida por serem ests dois os que mais se resentem do espirito de Alem-Rheno. (19CAQ, p.2)

Na ocorrência (66), todavia estabelece uma relação adverbial de modo com o sentido de completamente. Numa leitura atual dessa ocorrência, teríamos: “(...) a leitura do Fausto de Goethe e o livro de Rémusat sobre a nova filosofia alemã exerceram completamente sobre meu espírito uma impressão profunda e duradoura.”.

Como advérbio de reforço, segue a ocorrência de todavia em (67).

\section{(67) Reforço adverbial}

Como assi seja que em duas maneiras se faça a alguem enjuria: hua per engano, e outra per força, o engano perteece aa rraposa, e a força ao liom, e cadahua delas he muy estranha da natureza do homem. Mas todavia o engano he mais digno de sseer avorrecido. (15LO, p.17) 
Como se nota, em (67), todavia funciona apenas como reforço da direção argumentativa do enunciado encabeçado pelo mas.

Câmara (1975) e Castilho (2004) defendem que os itens adversativos, em geral, adquiririam, metonimicamente, esse valor de adversidade em contextos de co-ocorrência com outro adversativo. Os dados mostrados na tabela 6 acima apontam uma frequência muito baixa da função de reforço $(3,7 \%)$ de todavia.

Em (68), segue ocorrência em que todavia apresenta valor ambíguo entre leitura de modo e de adversidade.

\section{Advérbio de modo I/ Advérbio juntivo adversativo}

(68) E despois de terdes dito e Repricado todo o que vos mamdo, e vos mais pareçer que compre por algưu novo caso ou Reposta delRey, que se não pode adevinhar, não sayndo, porê, nada d'esta tençom e sentếnça, nê dando ocasiom que vos Responda cousa a que vos seja neçesareo Responder mais aspero do que vos vay apontado, se todavia elRey nã quyser mãdar corrigir estas Represareas, e sua Reposta for sem efeyto, ou de se desfazerê de todo, ou de se nellas sobre estar atee se o caso tornar a ver por justiça; e despois de vos hưa ou duas vezes a tall Reposta não terdes Recebida, dizemdo que a não aveis aimda por Reposta, e esperaraaes, e lhe pedires muyto por merçe que o queira milhor cuydar, e lembrarse do que the tendes dito de minha parte. (16CDJ3, p.10)

Em (68), todavia ocupa uma posição medial dentro de uma oração dependente. Essa ocorrência possibilita duas leituras - de modo e adversativa -. Numa leitura de modo, todavia poderia ser parafraseado por de todo modo, isto é, o locutor afirma para o seu interlocutor que ele faça algo se de todo modo o rei não quiser mandar corrigir as represálias. Já numa leitura adversativa, no primeiro enunciado, o locutor defende a ideia de que se deva procurar o rei para se ter a resposta; no segundo enunciado, entretanto, aponta para o seu interlocutor o que deve fazer, caso o rei não responda. 


\section{Advérbio juntivo adversativo}

(69) Eis aqui por que, entre tantas cousas difficeis e intrincadas que, n'essa noite, com esforço arrancava da memoria e da intelligencia me esqueceu esta simplicissima, e que me acompanha sempre o espirito como uma companheira mysteriosa - a lembrança dos que choram.

E todavia, meu amigo, se um bom syllogismo vale muito, uma lagrima bem quente, bem viva e bem sentida, deve valer tanto - ou muito mais ainda. O peso duma lagrima! (19CAQ, p.18)

(70) Estas circumstancias pareceriam sufficientes para me imporem um silencio, ou modesto ou desdenhoso. Não o são, todavia. (19CAQ, p.30)

Todavia, em (69), ocupa posição medial e estabelece apenas a relação semântica de adversatividade, em que, o segundo enunciado serve como um novo argumento - o peso de uma lágrima - para o que estava sendo dito no primeiro enunciado. A relação sintática de ligar as orações é estabelecida pelo conector $e$.

Em (70), todavia ocupa posição final e estabelece a relação de adversatividade entre as duas orações, uma vez que o primeiro enunciado traz o argumento de que as circunstâncias seriam suficientes para silenciá-lo, enquanto o segundo enunciado argumenta na direção oposta - as circunstâncias não são suficientes. A relação sintática entre os dois enunciados se dá por justaposição.

Segue, em (71), o valor prototípico de conjunção adversativa de todavia.

\section{(71) Conjunção de modo I/ Adversativa}

- Ai, senhoram disse Meraugis, eu soõ ainda novel cavaleiro e soõ de pequena nomeada, e rogo-vos por Deus que me leixedes ir convosco ataa que veja que vós havedes mester de companha, ca o coraçom me diz que vos há-de contecer alguu mal.

- Nom farám, disse Erec, se Deus quiser.

- Todavia, disse Meraugis, vos rogo que me leixedes convosco ir.

E el lho outorgou. (13DSG, p.10)

Na ocorrência (71), todavia apresenta características de uma conjunção prototípica, ou seja, ocupa posição inicial, articula as orações tanto no nível sintático quanto no nível semântico. Entretanto, no nível semântico, permite duas leituras, de modo e adversativa. Numa leitura de modo, todavia tem sentido de de todo modo, ou seja, o cavaleiro roga de todo 
modo a sua ida junto a Erec. Já, numa leitura adversativa, estabelece uma relação de contraargumentação, em que, o segundo enunciado, se vale da resposta dada no primeiro enunciado para estabelecer a argumentação contrária a resposta dada. Essa ambiguidade, entretanto, não se verifica na ocorrência (72), na qual prevalece o valor semântico de adversidade.

(72) Preços e juros em alta reforçam a tendência de desaquecimento econômico, o que deveria contribuir para o declínio da inflação. Todavia as aplicações especulativas nos mercados futuros sustentam os preços altos. (21FSP, jun.08)

Nessa ocorrência, todavia comporta-se como conjunção prototípica, pois ocupa posição inicial, articula os dois enunciados tanto no nível sintático quanto no nível semântico e estabelece a relação semântica de adversatividade, em que, no primeiro argumento, o locutor defende que ocorre um declínio da inflação, uma vez que os preços e juros estão em alta, para, no segundo argumento, concluir que a inflação não vai sofrer um declínio.

Na tabela 7, apresentamos o percentual de ocorrências em cada uma das posições sintáticas - inicial, medial e final - ocupadas por todavia.

\begin{tabular}{|c|c|c|}
\hline \multicolumn{2}{|c|}{ Posição/categoria } & Percentual \\
\hline \multirow[t]{2}{*}{ Inicial } & $\begin{array}{c}\text { Advérbio } \\
\text { juntivo }\end{array}$ & $\begin{array}{c}5 \\
(9,3 \%)\end{array}$ \\
\hline & Conjunção & $\begin{array}{c}9 \\
(16,7 \%)\end{array}$ \\
\hline \multirow[t]{2}{*}{ Medial } & Advérbio & $\begin{array}{c}20 \\
(37 \%)\end{array}$ \\
\hline & $\begin{array}{l}\text { Advérbio } \\
\text { juntivo }\end{array}$ & $\begin{array}{c}15 \\
(27,8 \%) \\
\end{array}$ \\
\hline \multirow[t]{2}{*}{ Final } & Advérbio & $\begin{array}{c}3 \\
(5,5 \%)\end{array}$ \\
\hline & $\begin{array}{l}\text { Advérbio } \\
\text { juntivo }\end{array}$ & $\begin{array}{c}2 \\
(3,7 \%)\end{array}$ \\
\hline & Total & $\begin{array}{c}54 \\
(100 \%) \\
\end{array}$ \\
\hline
\end{tabular}

Tabela 07: Frequência das posições sintáticas de todavia na história do português (séc. XIII a XXI) 
A partir das frequências apresentadas acima, 37\% das ocorrências de todavia se encontram na posição medial como advérbio, o que acaba caracterizando um estágio tardio de gramaticalização.

No gráfico 6, está apresentada a distribuição categorial de todavia por século, a fim de depreendermos o momento em se deu seu processo de mudança categorial.

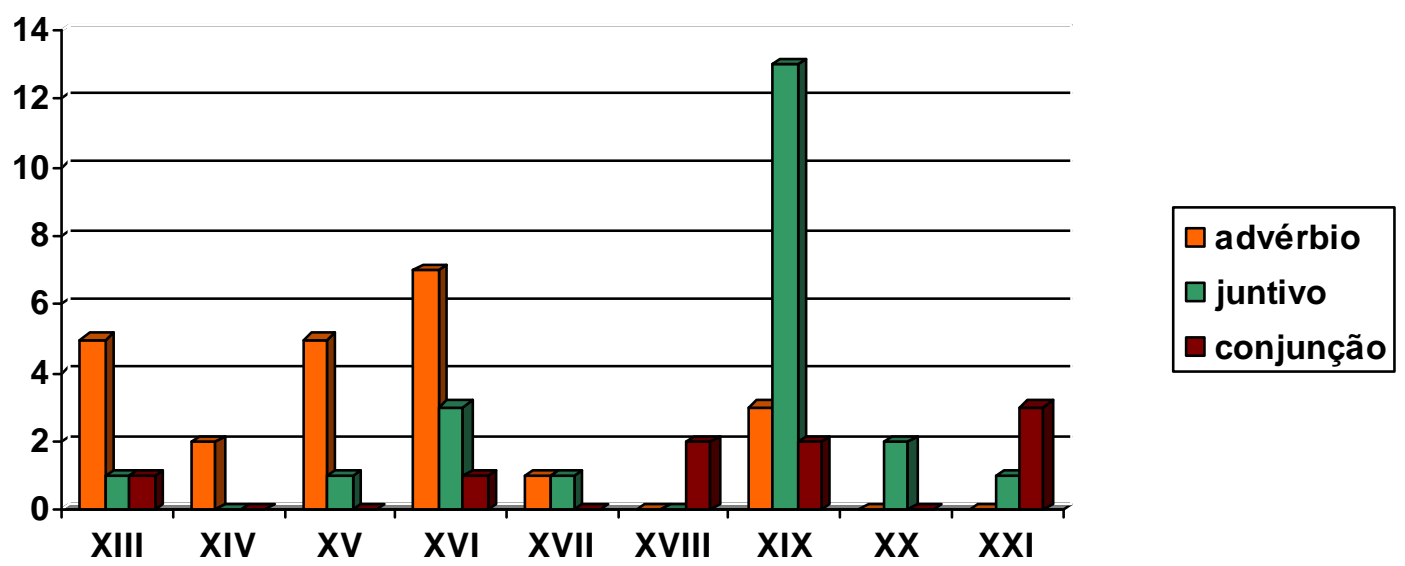

Gráfico 06: O desenvolvimento categorial de todavia do século XIII ao XXI

Até o século XVI, há o predomínio da função adverbial de todavia, que, no século XVII, se iguala com o uso juntivo, desaparecendo no século XVIII e reaparecendo no século XIX, rumo ao completo desaparecimento nos séculos XX e XXI. Na sincronia atual, destacase o uso conjuncional em relação à função juntiva, caracterizando o início do processo de mudança advérbio juntivo > conjunção, pois, como diagnosticamos na tabela 6 , a percentagem geral de usos como advérbio juntivo é significativamente maior que a percentagem dos usos conjuncionais. Acreditamos que, a partir da análise comparativa dos advérbios juntivos adversativos, poderemos afirmar o estágio de gramaticalização em que todavia se encontra.

Diante desses resultados, é possível propor que todavia passou por um processo de recategorização, que obedece a seguinte escala de gramaticalização: 
SINTAGMA

NOMINAL

COMO

ADVÉRBIO

ESPACIAL
ADVÉRBIO

JUNTIVO

\section{(CONJUNÇÃO)}

ADVÉRBIO D
MODO (I / II)

Em relação ao aspecto semântico, foram encontrados, como já foi mostrado na tabela 06, cinco types - modo I, modo II, ambíguo entre modo I e adversativo, reforço de um outro item adversativo e adversativo.

No gráfico 7, dado a seguir, pode-se observar o comportamento semântico de todavia ao longo dos séculos investigados. O uso modal I e II, em que o item tem valor de de todo modo e completamente, respectivamente, oscila entre os séculos estudados, desaparecendo, completamente, nos séculos XX e XXI . O uso ambíguo - modal/adversativo - e o uso como reforço de outro item adversativo funcionam como estágios intermediários para fixação do valor adversativo, ocorrendo entre o século mais inicial até o século XVI, em que a mudança parece se instaurar em favor do valor adversativo que ocorre desde o século mais inicial.

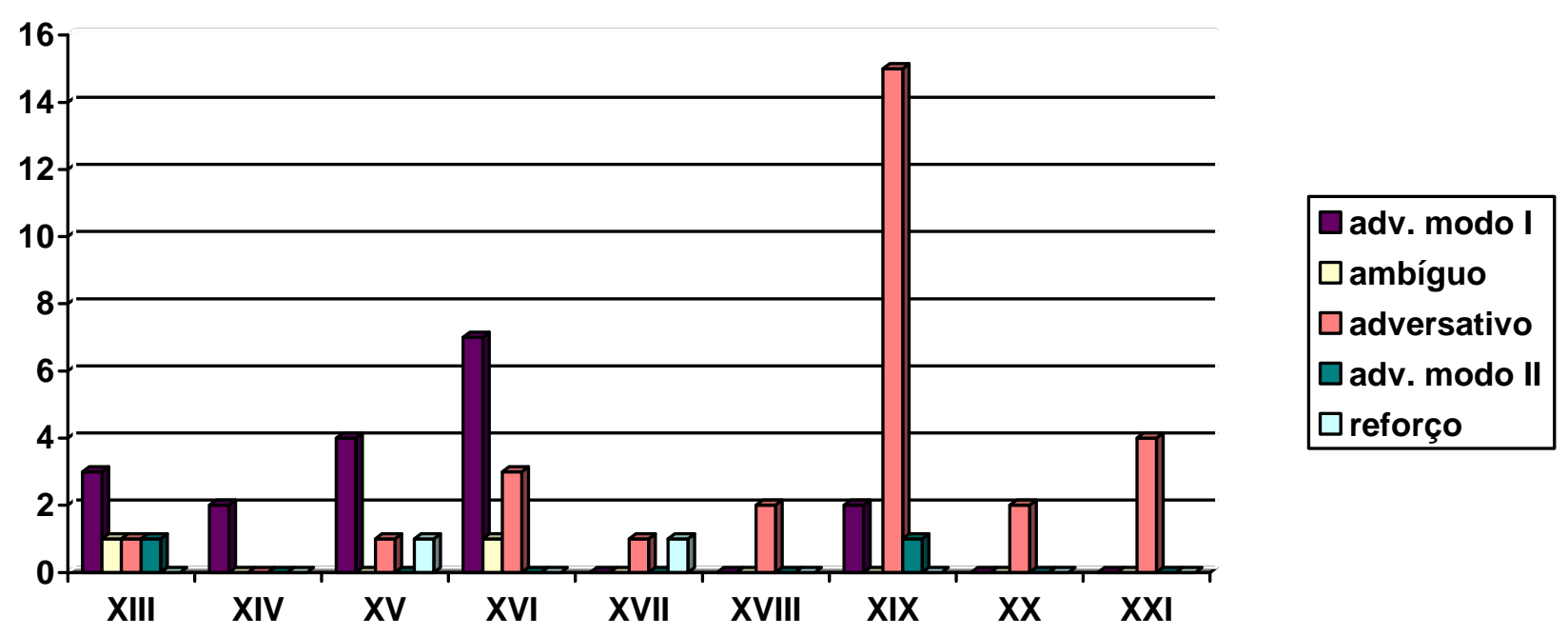

Gráfico 07: Os valores semânticos de todavia do século XIII ao XXI 
Uma possível escala de mudança das funções semânticas de todavia é a dada abaixo.

$$
\text { ESPAÇO > MODO }
$$$$
\left\{\begin{array}{l}
\text { AMBÍGUO } \\
\text { REFORÇO }
\end{array}\right\}>
$$

ADVERSATIVO

A mudança semântica de todavia pode ser explicada tanto por um processo metonímico como por um processo metafórico. Segundo Said Ali (1964) e Barreto (1999), todavia assumiu o valor adversativo em contextos negativos, via metonímia. Os resultados do controle da presença de negação nos dados investigados são explicitados na tabela 8 .

\begin{tabular}{l|l}
\hline \multicolumn{1}{c|}{ Contexto Negativo } & \multicolumn{1}{c}{ Frequência } \\
\hline Negação na primeira oração & $9(47.4 \%)$ \\
\hline Negação na segunda oração & $8(42.1 \%)$ \\
\hline Negação nas duas orações & $2(10.5 \%)$ \\
\hline Total & $19(100 \%)$ \\
\cline { 2 - 2 }
\end{tabular}

Tabela 08: O uso de todavia em presença de elemento de negação ao longo da história do português (séc. XIII a XXI)

Das 54 ocorrências investigadas, 35,2\% (=19 ocorrências) apresentam-se em contexto de negação. Diante dos percentuais, podemos afirmar que o contexto negativo não é um fator favorável para a instauração do valor adversativo de todavia, refutando, assim, a hipótese de Said Ali (1964) e Barreto (1999). Em (74), exemplificamos todavia no contexto de negação.

(75) Posso dar rumo à minha vida sem a miragem diante dos olhos. Em fins deste abril devo vender uma casa em São Paulo e então te mandarei o conto. Não garanto, todavia. As coisas falham 9 vezes para acertar 1/2: não obstante estive em São Paulo há poucos dias e ficou fechado o negócio, dependendo do recebimento por parte do comprador de uma letra do Governo, que vence nos fins de abril. (20CE-C, p.5)

Em (74), a relação de contrajunção é estabelecida entre enviar o dinheiro, em dependência da venda da casa e não garantir que enviará o dinheiro. Sendo assim, essa relação 
é estabelecida no nível epistêmico e não no nível do conteúdo. Nessa ocorrência, todavia reitera a direção oposta já veiculada pelo advérbio de negação não.

Se considerarmos a escala de abstratização espaço > (tempo) > texto (HEINE et al., 1991), verificaremos que todavia se implementa por meio dela, sem recurso ao passo intermediário. ${ }^{3}$ Enquanto advérbio espacial, todavia ocupa o domínio do espaço, e, ao passar a integrar o domínio funcional da relação adversativa, adentra o domínio do texto, como mostra a escala de abstratização dada abaixo.

ESPAÇO
em todo o caminho

(TEMPO)
TEXTO Adversativo

Segundo Rocha (2006), o uso intermediário de todavia com o valor de de todo modo ou de toda maneira e completamente é resultado de um processo de abstratização do valor original do pronome todo e do nome caminho, via, que servem de fonte para os novos valores semânticos.

Considerando o trabalho de Swetser (1990), de base metafórica, sobre anyway (inglês) e tuttavia (italiano), que significam literalmente em todo o caminho, mas integram o sistema funcional das adversativas, podemos notar que todavia, em português, apresenta trajetória semelhante, embora o uso espacial não tenha sido o valor que apresentou maior frequência na sincronia mais inicial. Segundo a autora, a estrutura lógica e conversacional que envolve anyway e tuttavia é possível de ser estendida a todavia, ou seja, o seu uso mais gramaticalizado como adversativo é uma extensão de seu significado físico, uma vez que a base cognitiva da adversatividade encontra amparo em um esquema do tipo: por nenhum caminho (mental ou conversacional) que tomemos chegaremos ao ponto (à conclusão) esperado(a).

\footnotetext{
3 A representação da categoria tempo entre parêntese significa que a passagem espaço > texto não necessariamente é intermediada por recurso a significados temporais.
} 
A escala que explicaria a mudança semântica de todavia, via metáfora e metonímia, pode ser esquematizada da seguinte maneira:

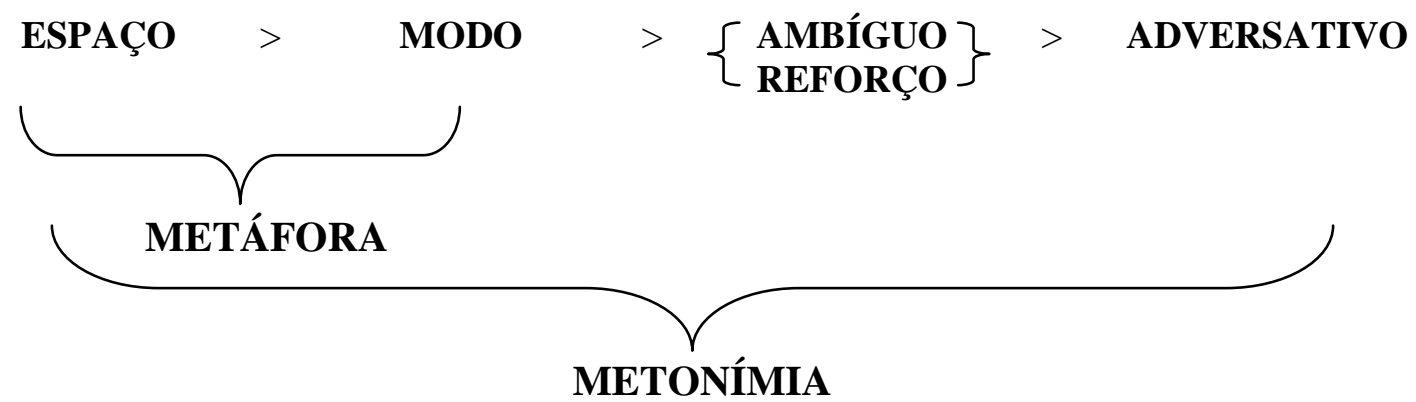

O resultado das estratégias argumentativas dos usos adversativos de todavia encontram-se apresentados na tabela 9, de acordo com os séculos investigados.

\begin{tabular}{|c|c|c|c|c|c|c|c|c|c|c|}
\hline Estratégias argumentativas & $\mathbf{X I I}$ & $\mathbf{X N}$ & $\mathbf{X V}$ & $\mathbf{X M}$ & $\mathbf{X Y}$ & $\mathbf{X Y I I}$ & $\mathbf{X X}$ & $\mathbf{X X}$ & $\mathbf{X X I}$ & Total \\
\hline contra-argumentação & 1 & - & - & 1 & - & - & 3 & 1 & 2 & $\begin{array}{c}8 \\
(25 \%)\end{array}$ \\
\hline negação de inferência & - & - & - & 2 & - & 1 & 5 & - & - & $\begin{array}{c}8 \\
(25 \%)\end{array}$ \\
\hline $\begin{array}{l}\text { direção independente (acréscimo } \\
\text { de novo argumento) }\end{array}$ & 1 & - & - & - & - & - & 3 & - & 1 & $\begin{array}{c}5 \\
(15,7 \%)\end{array}$ \\
\hline $\begin{array}{l}\text { restrição } \\
\text { (acréscimo) }\end{array}$ & - & - & - & 1 & - & 1 & 1 & - & - & $\begin{array}{c}3 \\
(9,4 \%)\end{array}$ \\
\hline oposição & - & - & 1 & - & - & - & 1 & 1 & - & $\begin{array}{c}3 \\
(9,4 \%)\end{array}$ \\
\hline $\begin{array}{l}\text { compensação } \\
\text { informação) }\end{array}$ & - & - & - & - & 1 & - & - & - & 1 & $\begin{array}{c}2 \\
(6,2 \%)\end{array}$ \\
\hline $\begin{array}{lll}\begin{array}{l}\text { compensação } \\
\text { informação) }\end{array} & \text { (substituição } & \text { de } \\
\end{array}$ & - & - & - & - & 1 & - & 1 & - & - & $\begin{array}{c}2 \\
(6,2 \%) \\
\end{array}$ \\
\hline $\begin{array}{l}\text { direção independente (acréscimo } \\
\text { de novo foco) }\end{array}$ & - & - & - & - & - & - & 1 & - & - & $\begin{array}{c}1 \\
(3,1 \%)\end{array}$ \\
\hline Frequência token & 2 & - & 1 & 4 & 2 & 2 & 15 & 2 & 4 & $\begin{array}{c}32 \\
(100 \%)\end{array}$ \\
\hline Frequência type & 2 & - & 1 & 3 & 2 & 2 & 7 & 2 & 3 & 9 \\
\hline
\end{tabular}

Tabela 09: Estratégias argumentativas de todavia (adversativo) do século XIII ao XXI

De acordo com o percentual apresentado, as estratégias mais frequentes são a contraargumentação e a negação de inferência, totalizando juntas, 50\%. Porém, se observarmos as 
estratégias argumentativas atualizadas por século, verificaremos que, no século XXI, há apenas três estratégias sendo atualizadas e, dessas três, a contra-argumentação parece ser a preferida. No século XIX, que apresenta a maior frequência de usos adversativos, são atualizadas sete estratégias argumentativas, revelando, assim, o caráter multifuncional de todavia nesse período.

O fato de a multifuncionalidade (types) de todavia ser menor no século XXI, possivelmente, o afastará, num cline de gramaticalidade, dos usos de itens mais gramaticalizados, que se espera mais multifuncionais.

\subsubsection{Entretanto}

Segundo Houaiss (2001), o item entretanto é datado do século XIII, mas, no corpus investigado nessa pesquisa, o item surge somente no século XVI. Esse item é formado da junção da preposição entre com o pronome tanto e, segundo Barreto (1999), tem o sentido originário de "entre tantas coisas". No português moderno, mais especificamente no século XVII, encontramos ainda um uso de entretanto como advérbio temporal, com o sentido de enquanto isso sucede. Além da grafia corrente, nos textos investigados, encontramos as formas entre tanto, no entretanto. ${ }^{4}$ A forma aglutinada ocorre já nos textos do século XVI.

No gráfico 8, apresentamos a frequência token de entretanto no período dos séculos XVI a XXI.

\footnotetext{
${ }^{4}$ Essa forma foi encontrada no século XIX, com o sentido de adversativo. Segundo Barreto (1999), pode-se considerar uma forma analógica a no entanto.
} 


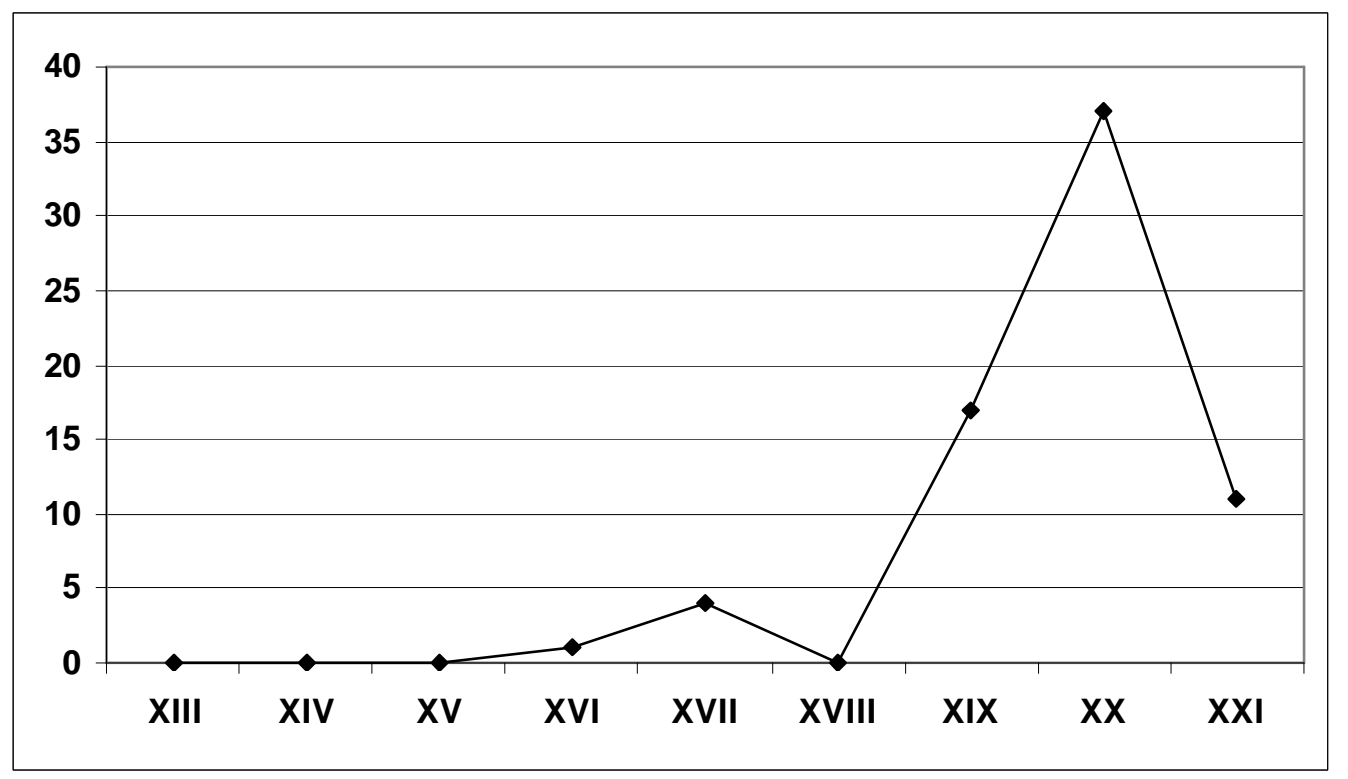

Gráfico 8: Frequência token de entretanto do século XVI ao XXI

A partir da análise do gráfico 8, constatamos que foram registradas, no corpus, as primeiras ocorrências de entretanto no século XVI e, entre os séculos XVI e XVIII, o item apresentou uma frequência muito baixa, chegando a nulidade no século XVIII. A frequência token de entretanto aumenta significativamente entre os séculos XIX e XX. No século XXI, há uma diminuição na frequência de uso, que pode ser decorrente de diversos fatores já explicitados no início deste capítulo.

Na tabela 10, à página seguinte, expomos a frequência token e type de entretanto.

\begin{tabular}{|c|c|c|c|}
\hline Frequência & \multicolumn{3}{|c|}{ Frequência type } \\
\hline 70 & \multicolumn{3}{|c|}{03} \\
\hline & Categoria & Valor semântico & Totais \\
\hline & $\begin{array}{l}\text { Conjunção } \\
(32,9 \%)\end{array}$ & Adversativa & $\begin{array}{c}23 \\
(32,9 \%) \\
\end{array}$ \\
\hline & $\begin{array}{l}\text { Advérbio } \\
\text { juntivo } \\
(64,3 \%)\end{array}$ & Adversativo & $\begin{array}{c}45 \\
(64,3 \%)\end{array}$ \\
\hline & \multirow[t]{2}{*}{$\begin{array}{l}\text { Advérbio } \\
(2,9 \%)\end{array}$} & $\begin{array}{l}\text { Companhia (entre tantas } \\
\text { coisas) }\end{array}$ & $\begin{array}{c}1 \\
(1,45 \%) \\
\end{array}$ \\
\hline & & $\begin{array}{l}\text { Temporal (enquanto isso } \\
\text { sucede) }\end{array}$ & $\begin{array}{c}1 \\
(1,45 \%)\end{array}$ \\
\hline
\end{tabular}

Tabela 10: Frequência token e type totais de entretanto na história do português (séc. XVI a XXI) 
Como se pode observar, entretanto distribui seus 70 tokens em 3 types sintáticos advérbio, 2,9\%, advérbio juntivo, 64,3\%, e conjunção, 32,9\%. Quanto às relações semânticas desempenhadas por entretanto, há também 3 types semânticos - adversativo $(97,1 \%)$, companhia $(1,45 \%)$ e temporal $(1,45 \%)$, distrubuídos da seguinte maneira: o type adversativo ocorre predominantemente como advérbio juntivo $(64,3 \%)$ e ocorre também como conjunção (32,9\%); o type companhia ocorre como advérbio (1,45\%) e o type tempo ocorre também como advérbio $(1,45 \%)$.

Levando em conta os percentuais apresentados na tabela 10, constata-se que entretanto ocorre predominantemente como advérbio juntivo com valor adversativo, type no qual se concentram $64,3 \%$ das ocorrências levantadas. Esse uso afasta-se do uso puramente adverbial, cujos valores semânticos, juntos (2,9\%), também se distanciam do uso conjuncional adversativo, que apresenta metade das ocorrências do uso como advérbio juntivo, $(32,9 \%)$. Diante da alta percentagem de usos adversativos e da alta percentagem como advérbio juntivo, podemos inferir que o processo de mudança semântica está além do processo de mudança sintática, como veremos no decorrer da análise.

De (78) a (81), seguem ocorrências exemplificativas de cada um dos types sintáticosemânticos considerados na tabela 10 .

\section{(78) Advérbio de lugar figurado}

Tomada essa resolução se pôs em ordem para este edifício, fazendo primeiro um cercamento forte de pau a pique para os trabalhadores e soldados poderem estar seguros do gentio e como foi acabada arrumou a cidade dela para dentro arruando-a por boa ordem com as casas cobertas de palma ao modo do gentio em as quais por entretanto se agasalharam os mancebos e soldados que vieram na armada e como todos foram agasalhados ordenou de cercar esta cidade de muros de taipa grossa. (16NB, p.56)

Em (78), entretanto traz uma circunstância ao enunciado, estabelecendo uma relação de lugar figurado que pode ser parafraseado por entre tantas coisas, valor original do item. Ao 
interpretarmos a ocorrência, tem-se: "arrundo-a por boa ordem com as casas cobertas de palma ao modo do gentio, nas quais por entre tantas coisas se agasalharam os mancebos e soldados que vieram na armada (...)." Em (78), mostramos ocorrência de entretanto com valor temporal.

\section{(79) Advérbio temporal}

Eu sei, que cá- be nos limites da minha Jurisdição | punir esta especie de dezobediencia, e dar por inutil, ede nenh__ efeito alicen | ça concedida; mas hé justo, que esta Ca- $\mid$ mara, eas futuras conheção quanto dé- vem ser respeitádas, e venerádas as ordens | dos senhores Generáes; epor isso oponho | na Prezensa deVossa Excelencia para da | sua parte lho extranhar, com Piedade | sim, mas de forma, que elles conheção agra- | vidade do seo erro, e dasua facilidade, e | que este Padre conheça tamb_ _, que de- | ve esperar asoberana Decizão, que elle | mesmo prócurou, e entretanto aco- ||| Acomodar se, e não au mentar as | perturbaçoens, partidos e dezunião em | que Vive este Povo: Espero a Rezolução de Vossa Excelencia para saber o que | eide obrar.| (17CBS, p.147)

Em (79), entretanto também traz uma circunstância para o enunciado, estabelecendo uma relação semântica temporal, podendo ser parafraseado por enquanto isso sucede. Sendo assim, temos: “(...) é justo que esta câmara e as futuras conheçam quanto devem ser respeitadas e veneradas as ordens dos senhores generais, e, por isso, oponho na presença de Vossa Excelência para da sua parte, com piedade, sim, mas de forma que eles conheçam a gravidade do seus erros e da sua facilidade e que este Padre conheça também que deve esperar a soberana decisão, que ele mesmo procurou, e enquanto isso sucede ele deve se acomodar e não aumentar as perturbações, partidos e desunião em que vive este povo."

Em (80), segue o uso adverbial adversativo do item.

\section{(80) Advérbio juntivo adversativo}

Entregar a construção e a exploração de rodovias à iniciativa privada é uma atitude justa e, no mais das vezes, necessária. O Rodoanel, entretanto, foi concebido para integrar as várias estradas que saem da capital paulista e, assim, aliviar o trânsito de caminhões nas marginais Tietê e Pinheiros -é isso, aliás, que justifica o investimento público. (21FSP, jun.06) 
Entretanto, em (80), ocupa posição medial, estabelecendo relação de adversatividade entre as duas orações. Essa relação é estabelecida entre a conclusão do primeiro argumento de que todas as construções e explorações de rodovias serão entregues à iniciativa privada, logo o Rodoanel também, e a conclusão do segundo argumento de que o Rodoanel será um investimento público.

\section{(81) Conjunção Adversativa}

Dois tangos me produzem mal-estar e três tangos provocam em mim náuseas positivas. Entretanto o meu amigo dom Carlos Reverbel adora tangos. (20GN, p.121)

$\mathrm{Na}$ ocorrência (81), entretanto ocupa posição inicial, estabelecendo a ligação sintática entre as orações. Além da ligação sintática, entretanto estabelece a relação semântica de adversatividade no nível epistêmico, pois não há nenhuma oposição, no nível do conteúdo, entre o locutor não apreciar tangos e o seu amigo, dom Carlos Reverbel, adorá-los. Sendo assim, a oposição no nível epistêmico se dá entre o fato do locutor não gostar de tangos e o seu amigo, dom Carlos Reverbel, adorar tangos.

Na tabela 11, apresentamos o percentual de ocorrências em cada uma das posições sintáticas - inicial, medial e final - ocupadas por entretanto.

\begin{tabular}{l|c|c}
\hline \multicolumn{2}{l|}{ Posição/categoria } & Percentual \\
\hline Inicial & Adv juntivo & $\begin{array}{c}1 \\
(1,4 \%)\end{array}$ \\
\cline { 2 - 3 } & Conjunção & $\begin{array}{c}23 \\
(32,9 \%)\end{array}$ \\
\hline \multirow{2}{*}{ Medial } & Advérbio & 2 \\
& & $(2,9 \%)$ \\
\cline { 2 - 3 } & Advérbio & 43 \\
& juntivo & $(61,4 \%)$ \\
\hline Final & Advérbio & 1 \\
& juntivo & $(1,4 \%)$ \\
\hline \multicolumn{2}{|c}{ Total } & 70 \\
\cline { 2 - 3 } & \multicolumn{2}{c}{$(100 \%)$} \\
\cline { 2 - 3 }
\end{tabular}

Tabela 11: Frequência das posições sintáticas de entretanto na história do português (séc. XVI a XXI) 
Verificamos que, em $61,4 \%$ dos casos, entretanto ocorre na posição medial como advérbio juntivo. Diante desses resultados gerais, concluímos que entretanto, embora guarde resquícios de sua fonte adverbial, está mais próximo da posição inicial, típica das conjunções prototípicas, que apresenta percentual de 32,9\%. Uma análise um pouco mais detalhada dessa constatação pode ser feita pelo cruzamento dos fatores categoria e século, como se observa no gráfico 9.

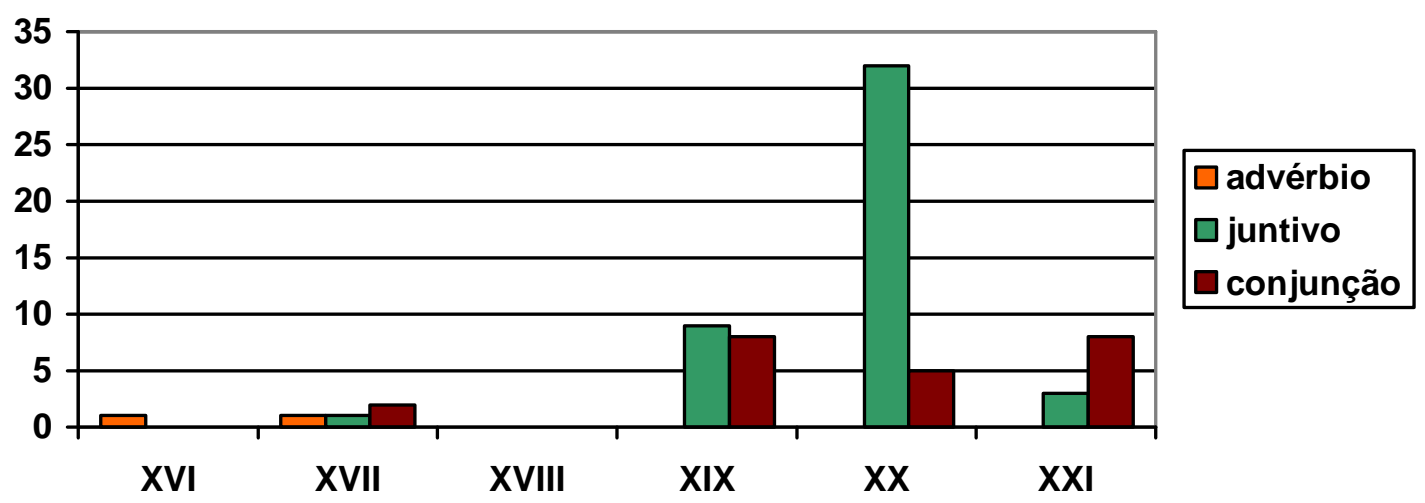

Gráfico 09: O desenvolvimento categorial de entretanto do século XVI ao XXI

Observando o gráfico 09, constatamos que entretanto como advérbio ocorreu, numa frequência muito baixa, nos séculos XVI e XVII. No século XVII, embora entretanto seja usado com frequência baixa, há o convívio das 3 categorias - advérbio, advérbio juntivo e conjunção. A frequência já baixa de entretanto no século XVII chega à nulidade no século XVIII, reaparecendo no século XIX, apenas como advérbio juntivo e conjunção. A partir do século XIX, pode-se dizer que a mudança está instaurada, em favor do uso conjuncional, que apresenta, na sincronia atual, uma frequência um pouco mais acentuada que o percentual de advérbio juntivo.

De acordo com os resultados apresentados, uma possível escala de gramaticalização das categorias sintáticas para entretanto seria: 
Em relação aos types semânticos, como foi demonstrado na tabela 09, entretanto apresenta três types - lugar figurado, temporal e adversativo. Diferentemente dos demais itens investigados, entretanto não tem ocorrências de reforço nem valores ambíguos. No gráfico 10, expomos os valores semânticos de entretanto do séculos XVI ao XXI.

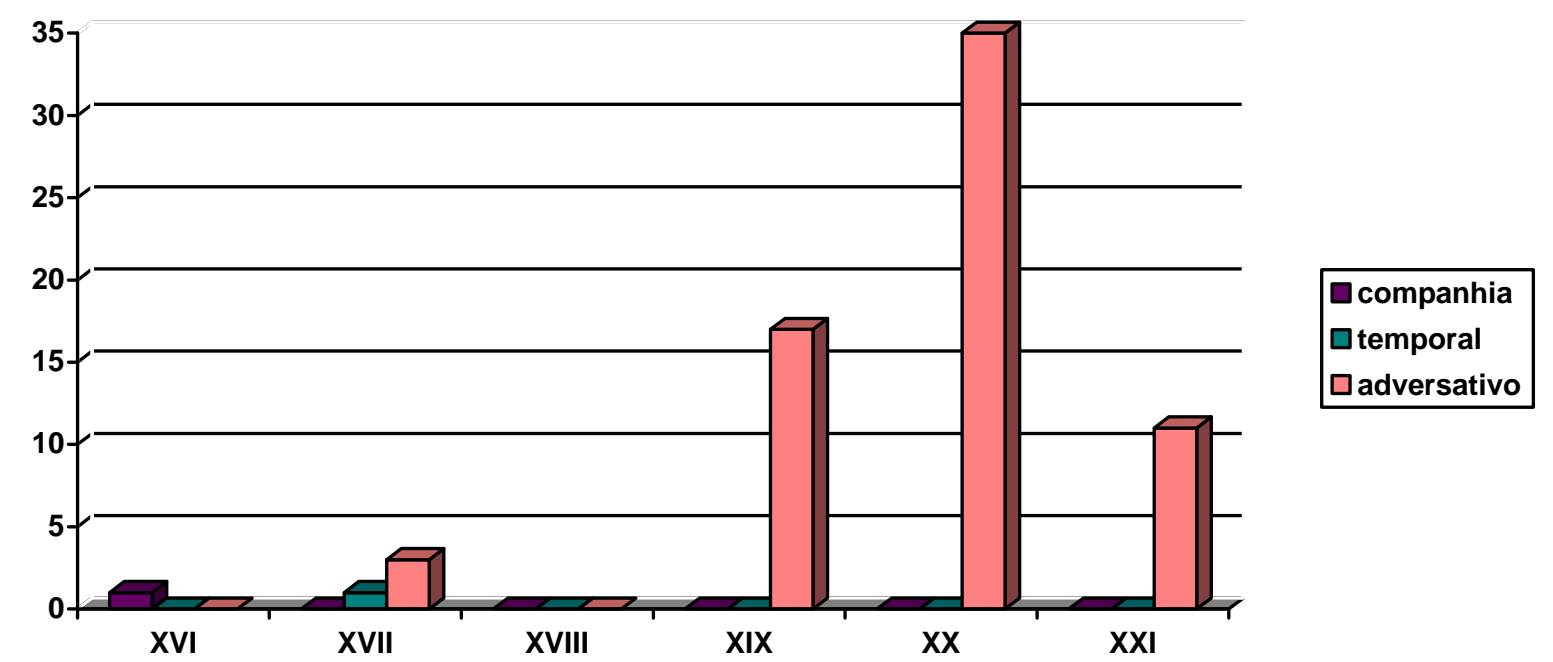

Gráfico 10: Os valores semânticos de entretanto dos séculos XVI ao XXI

No gráfico 10, nota-se que os valores de companhia e temporal, que seriam os valores-base de entretanto, ocorrem numa frequência baixa nos séculos XVI e XVII. O valor adversativo, por sua vez, começa a ser usado a partir do século XVII e apresenta uma frequência crescente até o século XX. No século XXI, há uma redução, devido ao tipo de texto jornalístico utilizado como representante desse século. Num primeiro momento, uma possível escala de gramaticalização das funções semânticas de entretanto seria:

$\underset{\text { FIGURADO }}{\text { LUGAR }}>$ TEMPO $>$ ADVERSATIVO


Essa mudança semântica, mostrada na escala acima, pode ser explicada tanto por um viés metafórico quanto por um viés metonímico. Pela metonímia, pode-se dizer que entretanto tenha instaurado o valor adversativo em contextos de negação ou precedido desses contextos, corroborando, assim, a proposta defendida por Said Ali (1964). Na tabela 12, apresentamos os percentuais de uso nesses contextos.

\begin{tabular}{|c|c|}
\hline Contexto Negativo & Frequência \\
\hline Negação na primeira oração & $16(50 \%)$ \\
\hline Negação na segunda oração & $13(40,6 \%)$ \\
\hline Negação nas duas orações & $3(9,4 \%)$ \\
\hline Total & $32(100 \%)$ \\
\hline
\end{tabular}

Tabela 12: O uso de entretanto em presença de elemento de negação ao longo da história do português (séc. XVI a XXI)

O uso de entretanto em contextos negativos ou precedidos de negação corresponde a quase metade das ocorrências investigadas, isto é, 32/70 ocorrências (45,7\%). Dessas 32 ocorrências, 16 (50\%) apresentam o elemento de negação na primeira oração; 13 (40,6\%), na segunda oração e $3(9,4 \%)$, nas duas orações. Com base nesses percentuais, podemos afirmar que entretanto, ao ser usado nesses contextos, assimilou metonimicamente o valor de negação, passando, assim, a codificar uma estratégia de adversidade em que o argumento apresentado no primeiro enunciado é sempre o argumento negado no segundo enunciado. A ocorrência (83) exemplifica o uso de entretanto em contexto de negação.

(84) Embora tenhamos uma Lei que determina que todos os que, por falta de rendas, não podem servir na Guarda Nacional pertenção á Guarda Policial, a falta d'organisação d'esta força, faz com que ella apenas preste insignificante serviço, e só sirva d'estorvo para a administração, que vê-se todos os dias importunada com propostas para nomeação de comandantes, que nada fazem, e que procurão com ancia este posto para escaparem do serviço da Guarda Nacional, e a outros encargos a que são obrigados. Entretanto não se pode duvidar de que é esta a força que mais serviços poderia prestar, com menos perda da industria; e esta vantagem foi procurada pelos Legisladores quando crearão a Guarda Policial. (19DMA, p.14) 
A relação de adversatividade, em (84), é estabelecida entre o argumento de que a Guarda Policial não tem serventia e o argumento de que essa deveria ser a força que mais serviços poderia prestar. Essa relação que pode ser entendida como uma negação de inferência (uma vez que, se não há serventia para guarda, o interlocutor infere que essa não terá muitos serviços a prestar) é estabelecida pelo elemento negativo não, presente na segunda oração, após entretanto, que estaria reforçando o sentido expresso pelo item adversativo.

Por viés metafórico, a mudança semântica de entretanto se implementa, por meio da escala de abstratização espaço > tempo > qualidade (HEINE et al., 1991), em que os usos com valor semântico de entre tantas coisas se encaixaria no domínio do espaço, os usos com valor de enquanto isso sucede, no domínio do tempo e os usos com valor de adversativo, no domínio da qualidade, como se pode ver na escala abaixo.

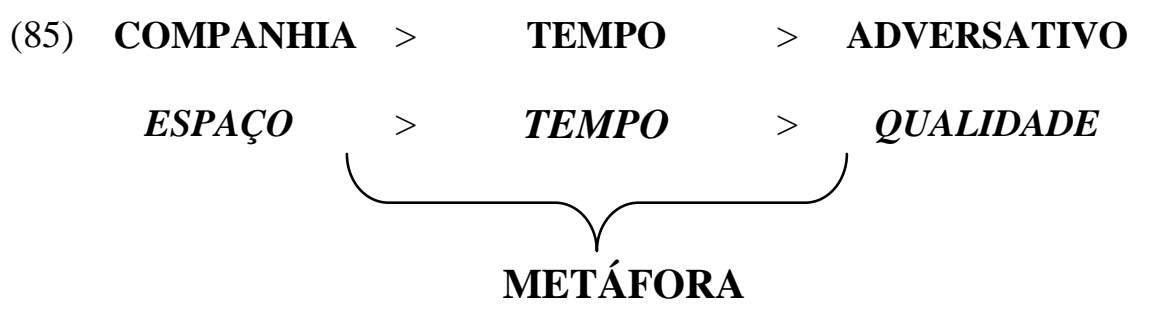

Em relação aos usos adversativos, são diferentes as estratégias argumentativas acionadas no emprego de entretanto durante os séculos investigados, como podemos observar pelos resultados que se encontram na tabela 13, à página seguinte. 


\begin{tabular}{|c|c|c|c|c|c|c|c|}
\hline Estratégias argumentativas & $\mathbf{X Y}$ & $\mathbf{X Y I}$ & XYII & $\mathbf{X X}$ & $\mathbf{X X}$ & $\mathbf{X X I}$ & Total \\
\hline contra-argumentação & - & 2 & - & 7 & 16 & 6 & $\begin{array}{c}31 \\
(45,6 \%) \\
\end{array}$ \\
\hline negação de inferência & - & - & - & 4 & 6 & 2 & $\begin{array}{c}12 \\
(17,6 \%)\end{array}$ \\
\hline $\begin{array}{ll}\text { direção independente (acréscimo de } \\
\text { novo foco) }\end{array}$ & - & 1 & - & 1 & 7 & 1 & $\begin{array}{c}10 \\
(14,7 \%)\end{array}$ \\
\hline $\begin{array}{l}\text { compensação } \\
\text { (acréscimo de informação) }\end{array}$ & - & - & - & - & 7 & - & $\begin{array}{c}7 \\
(10,3 \%) \\
\end{array}$ \\
\hline $\begin{array}{l}\text { restrição } \\
\text { (acréscimo) }\end{array}$ & - & - & - & 3 & - & - & $\begin{array}{c}3 \\
(4,4 \%)\end{array}$ \\
\hline oposição & - & - & - & 2 & - & - & $\begin{array}{c}2 \\
(2,9 \%) \\
\end{array}$ \\
\hline marcador de surpresa & - & - & - & - & 1 & - & $\begin{array}{c}1 \\
(1,5 \%)\end{array}$ \\
\hline $\begin{array}{l}\text { direção independente (acréscimo de } \\
\text { novo tema) }\end{array}$ & - & - & - & - & - & 1 & $\begin{array}{c}1 \\
(1,5 \%)\end{array}$ \\
\hline $\begin{array}{lll}\text { direção independente (acréscimo de } \\
\text { novo argumento) }\end{array}$ & - & - & - & - & - & 1 & $\begin{array}{c}1 \\
(1,5 \%)\end{array}$ \\
\hline Frequência token & - & 3 & - & 17 & 37 & 11 & $\begin{array}{c}68 \\
(100 \%)\end{array}$ \\
\hline Frequência type & - & 2 & - & 5 & 5 & 5 & 10 \\
\hline
\end{tabular}

Tabela 13: Estratégias argumentativas de entretanto (adversativo) do século XVI ao XXI

Assim como os demais itens analisados, no percentual geral, a estratégia argumentativa mais frequente é a de contra-argumentação, usada em 45,6\% das ocorrências de entretanto com valor adversativo. Da análise por século, constatamos que, durante os séculos XIX e XXI, em que houve uma frequência token total oscilante, as estratégias argumentativas se mantiveram praticamente estáveis, se considerarmos que três das cinco verificadas - contra-argumentação, negação de inferência e direção independente com acréscimo de novo foco - fixam-se nesse período de tempo.

Do século XVII, século em que ocorreram as primeiras ocorrências de entretanto com valor adversativo, para o século XIX, houve um aumento no número de manobras argumentativas, ocasionando, consequentemente, aumento na frequência token do item, como observamos no gráfico 8 . 
Como exemplo da estratégia de argumentação mais recorrente, tem-se a ocorrência em (86).

(86) O novo documento representa um avanço em relação às manobras que já foram feitas pela polícia e pela própria Promotoria para evitar punições. Fica, entretanto, muito aquém de dar um novo rumo ao caso. (21FSP, ago.07)

$\mathrm{Na}$ ocorrência (86), a relação de contra-argumentação é estabelecida entre a conclusão extraída do primeiro enunciado - como o novo documento é um avanço, o caso terá um rumo brevemente - e a conclusão do segundo argumento - o caso está muito aquém de ter um rumo -, o que contraria o argumento anterior. Diante das duas conclusões, a conclusão geral do enunciado tende para o segundo enunciado.

\subsubsection{No entanto}

O advérbio juntivo no entanto (entanto) no português arcaico, é datado do século XIII, segundo Houaiss (2001). De acordo com Barreto (1999), o item se formou da justaposição da preposição latina in ao pronome indefinido tantum, tornando-se um advérbio com valor de "por isso". No corpus investigado para essa pesquisa, encontramos um uso de entanto, no século XIII, com valor de por isso. Além desse valor, há registros, no século XIV, de entanto com valor temporal, significando "neste meio tempo, neste interím". Barreto (1999) supõe que esse valor temporal tenha sido adquirido por analogia ao valor das conjunções enquanto e tanto que, que apresentavam uma alta frequência de uso no português arcaico. 11 abaixo.

A frequência token de no entanto dos séculos XIII ao XXI é apresentada no gráfico 


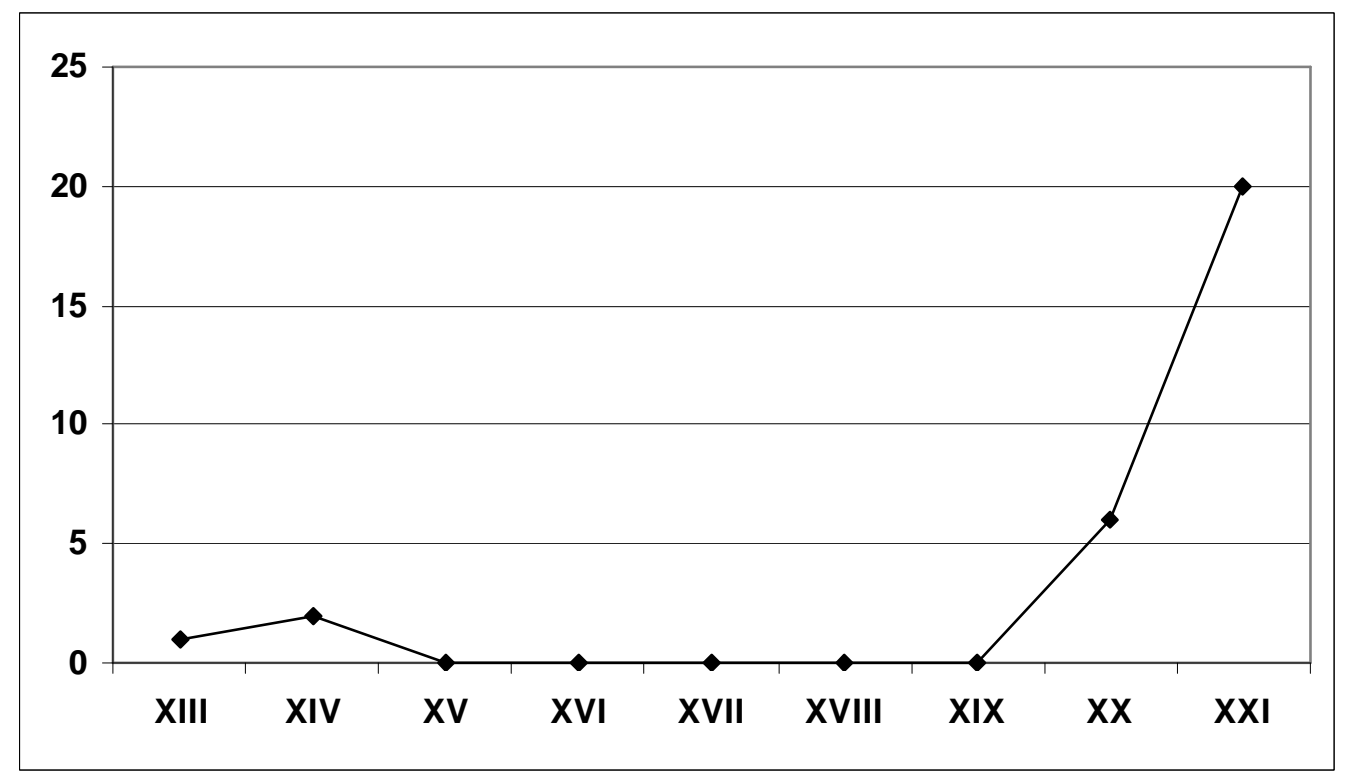

Gráfico 11: Frequência token de no entanto do século XIII ao XXI

De acordo com o gráfico acima, entanto ocorre nos séculos XIII e XIV e depois vem a ocorrer já com a forma no entanto somente nos séculos XX e XXI. Nos séculos XIII e XIV, o item apresenta uma frequência muito baixa que, juntamente com outros fatores, pode ter favorecido a nulidade nos períodos dos séculos XV a XIX. No seu reaparecimento no século $\mathrm{XX}$, no entanto já apresenta uma frequência maior que a inicial e aumenta, significativamente, do século XX para o XXI. A partir dessa trajetória frequencial, verifica-se que no entanto é documentado inicialmente no corpus apenas durante esses dois períodos, o que não significa que ele tenha estado fora do sistema nos períodos intermediários que precedem o seu ressurgimento. Contudo, diante dessa escassez de dados, é difícil determinar quando ocorreu a mudança da forma entanto para no entanto e as mudanças sintáticosemânticas pelas quais o item passou.

Na tabela 14, expomos a frequência token e type de no entanto durante os séculos investigados. 


\begin{tabular}{|c|c|c|c|}
\hline Frequência token & \multicolumn{3}{|c|}{ Frequência type } \\
\hline 29 & \multicolumn{3}{|c|}{04} \\
\hline & Categoria & Valor semântico & Totais \\
\hline & $\begin{array}{l}\text { Conjunção } \\
(41,4 \%)\end{array}$ & Adversativa & $\begin{array}{c}12 \\
(41,4 \%)\end{array}$ \\
\hline & $\begin{array}{l}\text { Advérbio juntivo } \\
(44,8 \%)\end{array}$ & Adversativo & $\begin{array}{c}13 \\
(44,8 \%)\end{array}$ \\
\hline & \multirow[t]{3}{*}{$\begin{array}{l}\text { Advérbio } \\
(13,8 \%)\end{array}$} & Advérbio fórico & $\begin{array}{c}1 \\
(3,4 \%)\end{array}$ \\
\hline & & Advérbio temporal & $\begin{array}{c}2 \\
(6,9 \%) \\
\end{array}$ \\
\hline & & Reforço & $\begin{array}{c}1 \\
(3,4 \%) \\
\end{array}$ \\
\hline & & Total & $\begin{array}{c}29 \\
(100 \%)\end{array}$ \\
\hline
\end{tabular}

Tabela 14: Frequência token e type totais de no entanto na história do português (séc. XIII a XXI)

No entanto apresenta 29 tokens divididos em 3 types sintáticos - advérbio 13,8\%, advérbio juntivo, 44,8\%, conjunção, 41,4\%. A partir desses percentuais, observamos que no entanto praticamente tem os mesmos percentuais para advérbio juntivo e conjunção, caracterizando, assim, um processo de mudança categorial já instaurado, rumo ao uso conjuncional. Em relação aos types semânticos, há 4 types, a saber: adversativo (86,2\%), fórico $(3,4 \%)$, temporal $(6,9 \%)$ e reforço $(3,4 \%)$. Enquanto o valor adversativo ocorre para as categorias de advérbio juntivo e conjunção, os demais valores ocorrem apenas para a categoria advérbio.

Diante da alta frequência como adversativo e da alta frequência como advérbio juntivo e conjunção, podemos inferir que tanto a mudança sintática quanto a mudança semântica de no entanto estão instauradas, como veremos na análise que será empreendida adiante.

De (87) a (91), seguem ocorrências exemplificativas de cada um dos types sintáticosemânticos considerados na tabela 14 . 
(87) Sintagma preposicionado como advérbio fórico

- Tu me profaças de traiçam; mais certamente nom me devem em tanto protaçar como ti; ca se tu nom fôsses mais aleivoso cavaleiro \| ca outro, nom mataras assi tua irmaã por ua sôo palavra que me prometeste. (13DSG, p.20)

Em (87), no entanto usado na forma original em tanto tem o sentido da origem latina de por isso. Consideramo-lo como advérbio porque ele traz uma circunstância de causa ao verbo devem. Quanto à relação de foricidade, em tanto recupera o que tinha sido dito na primeira oração para concluir. Sendo assim, temos que o fato do tu ter professado contra o eu, não faz com que o eu por isso professe contra o tu.

Em (88), exemplificamos o valor adverbial temporal de no entanto.

\section{(88) Sintagma preposicionado como advérbio temporal}

E depois que foy creçudo Sela, temeu-se Judas de o dar por marido a Tamar, e non lho dava. Entanto morreu a molher de Judas, e depois que se Judas confortou, foy huu dia a trosquiar as ovelhas, e Tamar soube-o, e desvestiu as vistiduras da viuvidade, e posesse eno caminho, per que avia Judas de vijr, e cobriu-se em guisa que a non conhecesse. (14BMP, p.42)

Na ocorrência acima, entanto traz uma circunstância de tempo à oração, podendo ser parafraseado por neste meio tempo, neste ínterim. Na ocorrência acima, podemos interpretar que a morte da mulher de Judas aconteceu na época em que Judas temia dar Sela como marido a Tamar.

Segue, em (89), o uso de no entanto como advérbio de reforço.

\section{(89) Advérbio de reforço}

Este ano é escasso de café, ano de nenhum lucro, mas no entanto tenho um colheitão com o qual espero enterrar os últimos cadáveres. (20CE-C, p.7)

Nessa ocorrência, no entanto reforça o argumento expresso pela conjunção mas que o lucro será bom, embora o café esteja escasso. Como os demais itens, no entanto também 
apresenta uma frequência muito baixa como advérbio de reforço, como diagnosticamos na tabela 14 .

Em seu uso juntivo, segue a ocorrência de no entanto em (90).

\section{(90) Advérbio juntivo Adversativo}

Vamos ver lá em cima. Está aí uma prova que era o Diabo! se vê que a casa é habitada e no entanto não tem ninguém. (20GN, p.148)

Na ocorrência (90), no entanto ocupa posição medial e estabelece a relação de contraste entre dois argumentos opostos, a casa estar habitada e não ter ninguém na casa.

Por fim, em (91), temos exemplificado o uso conjuncional de no entanto.

\section{(91) Conjunção Adversativa}

Os meninos ficaram num canto batendo papo, e as meninas, no canto oposto, dançando, às vezes, mas entre si. No entanto, no fim da tarde, os dois grupos se aproximaram. (21FSP, mar.03)

O juntivo no entanto, nessa ocorrência, ocupa posição inicial, articulando, assim, sintaticamente as orações, e estabelece também a relação semântica de adversatividade. Essa relação se dá entre a conclusão da primeira oração de que cada grupo (meninos e meninas) ficou num canto e a conclusão da segunda oração, em direção oposta, de que eles se aproximaram.

Para verificarmos as posições sintáticas ocupadas por no entanto na oração, apresentamos, na tabela 15, o percentual de ocorrências em cada uma das posições sintáticas inicial, medial e final. 


\begin{tabular}{|c|c|c|}
\hline \multicolumn{2}{|c|}{ Posição/categoria } & Percentual \\
\hline \multirow[t]{2}{*}{ Inicial } & Advérbio & $\begin{array}{c}2 \\
(6,9 \%)\end{array}$ \\
\hline & Conjunção & $\begin{array}{c}12 \\
(41,4 \%)\end{array}$ \\
\hline \multirow[t]{2}{*}{ Medial } & Advérbio & $\begin{array}{c}2 \\
(6,9 \%)\end{array}$ \\
\hline & $\begin{array}{l}\text { Advérbio } \\
\text { juntivo }\end{array}$ & $\begin{array}{c}13 \\
(44,8 \%)\end{array}$ \\
\hline & Tot & $\begin{array}{c}29 \\
(100 \%)\end{array}$ \\
\hline
\end{tabular}

Tabela 15: Frequência das posições sintáticas de no entanto na história do português (séc. XIII a XXI).

A partir da tabela 15, constatamos que há certo equilíbrio na frequência de no entanto em posição inicial $(41,4 \%)$ e medial $(44,8 \%)$, independentemente do valor semântico que assume. Observe-se ainda que, diferentemente dos outros itens, não se registram usos de no entanto em posição final.

No cruzamento categoria e século, no gráfico 12, podemos confirmar essa afirmação.

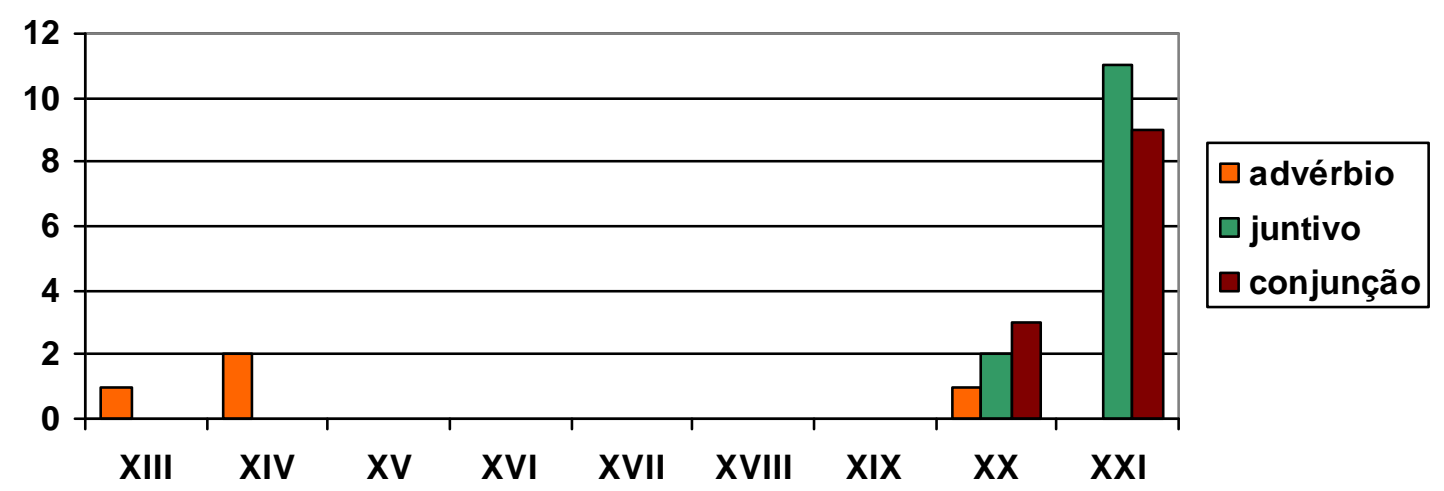

Gráfico 12: O desenvolvimento categorial de no entanto do século XIII ao XXI

O uso como advérbio aparece com frequência muito baixa, em todos os séculos em que ocorre. No século XX e XXI, as frequências como advérbio juntivo e como conjunção estão, praticamente, equiparadas, caracterizando, assim, uma possível passagem do estágio B (advérbio juntivo) para o estágio C (conjunção). Sendo assim, uma possível escala de gramaticalização de recategorização do item seria a que segue em (92). 
$(92)$

\section{ADVÉRBIO > ADVÉRBIO JUNTIVO >}

Quanto aos types semânticos, no entanto atualiza quatro types - fórico, temporal, reforço e adversativo -, como demonstrado na tabela 14. Agora, no gráfico 13, apresentamos a distribuição desses types pelos séculos em que no entanto ocorre.

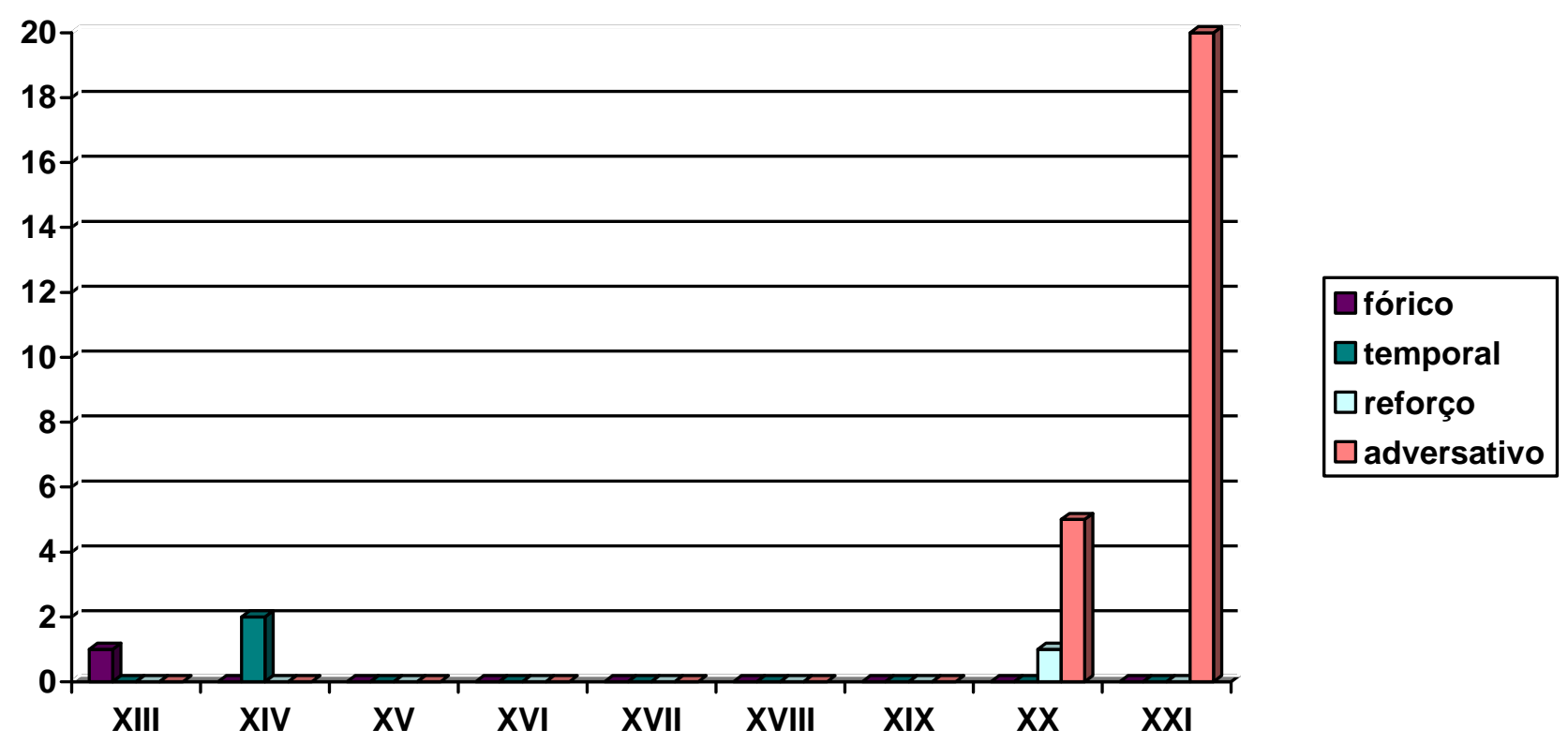

Gráfico 13: Os valores semânticos de no entanto dos séculos XIII ao XXI

Como afirmamos anteriormente, o fato de não termos encontrado ocorrências entre os séculos XV a XIX não nos permite afirmar como se deu exatamente a mudança semântica de no entanto de temporal para adversativo, o que será possível de projetar somente no cotejo entre os processos de mudanças de cada um dos itens. Diante do gráfico 13, constatamos que os usos fórico e temporal ocorrem nos séculos XIII e XIV, respectivamente. No século XX e XXI, identificamos apenas usos de no entanto como adversativo e como reforço de um outro item adversativo, esta última função verificada em apenas uma ocorrência do século XX. Com 
base em processos de abstratização, uma possível escala de gramaticalização das funções semânticas de no entanto seria a dada em (93).

$$
\text { FÓRICO > TEMPO > REFORÇO > ADVERSATIVO }
$$

Como vimos nos demais itens analisados, o fator presença de negação se apresentou relevante para explicar a instauração do valor adversativo. Sendo assim, é possível que esse fator também tenha favorecido o processo de mudança semântica de no entanto. Na tabela 16, apresentamos os percentuais de uso de no entanto em contextos de negação na primeira e na segunda oração.

\begin{tabular}{c|c}
\hline \multicolumn{1}{c|}{ Contexto Negativo } & Frequência \\
\hline Negação na primeira oração & $7(43,8 \%)$ \\
\hline Negação na segunda oração & $9(56,2 \%)$ \\
\hline Total & $16(100 \%)$ \\
\cline { 2 - 2 } &
\end{tabular}

Tabela 16: O uso de no entanto em presença de elemento de negação ao longo da história do português (séc XIII a XXI)

Para no entanto, o fator presença de negação também se mostrou relevante, uma vez que 55,2\% (16/29) das ocorrências investigadas se encontram em contexto de negação. Dessas 16 ocorrências, 56,2\% tem o elemento de negação na segunda oração e 43,8\%, na primeira. Diante desse percentual expressivo apresentado pelo uso de no entanto em contexto de negação, pode-se concluir que esse é um fator significante para a mudança semântica que deve ter sido instaurada durante as sincronias em que não encontramos, no corpus , ocorrências. ${ }^{5}$ Na ocorrência (93), exemplificamos o uso de no entanto em contexto de negação.

\footnotetext{
${ }^{5}$ Barreto (1999) encontra ocorrências de no entanto (entanto) nos séculos XVI e XX, mas a autora não explicita quais os valores encontrado em cada um dos séculos.
} 
(94) Parabenizo os repórteres Alencar Izidoro e Aureliano Biancarelli pela reportagem "Estado reduz passe livre a doentes" (Cotidiano, 29/10), por meio da qual conseguiram explicar e transmitir com fidelidade o objetivo da resolução que trata da concessão de gratuidade aos portadores de deficiência no transporte coletivo metropolitano. No entanto gostaria de registrar também que, infelizmente, não é possível fazer o mesmo comentário em relação ao título da reportagem, que, no meu entender, transmite a idéia equivocada de que o Estado esteja cometendo uma injustiça. (21FSP, nov.03)

Na ocorrência acima, a segunda oração - "no entanto gostaria de registrar também que, infelizmente, $\underline{\text { não }}$ é possível fazer o mesmo comentário em relação ao título da reportagem, que, no meu entender, transmite a idéia equivocada de que o Estado esteja cometendo uma injustiça" -, nega, por meio de no entanto, do prefixo -in e do elemento de negação não, a conclusão da primeira oração - Alencar Izidoro e Aureliano Biancarelli fizeram uma reportagem totalmente fiel ao fato.

Quanto aos usos adversativos de no entanto, observamos as diferentes estratégias argumentativas usadas nos séculos XX e XXI, em que há ocorrências adversativas do item. Os resultados se encontram na tabela abaixo.

\begin{tabular}{l|c|c|c}
\hline Estratégias argumentativas & XX & XX & Total \\
\hline contra-argumentação & 3 & 11 & $\begin{array}{c}14 \\
(53,8 \%)\end{array}$ \\
\hline $\begin{array}{l}\text { compensação } \\
\text { (acréscimo de informação) }\end{array}$ & 1 & 5 & $\begin{array}{c}6 \\
(23 \%)\end{array}$ \\
\hline negação de inferência & - & 3 & $\begin{array}{c}3 \\
(11,5 \%)\end{array}$ \\
\hline $\begin{array}{l}\text { direção independente } \\
\text { (acréscimo de novo argumento) }\end{array}$ & 1 & - & $\begin{array}{c}1 \\
(3,9 \%)\end{array}$ \\
\hline $\begin{array}{l}\text { oposição } \\
\text { Frequência token }\end{array}$ & 1 & - & $\begin{array}{c}1 \\
(3,9 \%)\end{array}$ \\
\hline $\begin{array}{l}\text { direção independente } \\
\text { (acréscimo de novo foco) }\end{array}$ & - & 1 & $\begin{array}{c}1 \\
(3,9 \%)\end{array}$ \\
\hline \multicolumn{1}{c|}{ Frequein type } & 4 & 4 & $\begin{array}{c}26 \\
(100 \%)\end{array}$ \\
\hline
\end{tabular}

Tabela 17: Estratégias argumentativas de no entanto (adversativo) dos séculos XX e XXI

Para no entanto, a estratégia argumentativa que apresentou alta frequência foi, como para os demais itens, a contra-argumentação, com 53,8\%. Tanto no século XX como no XXI, 
o item é usado em quatro estratégias, sendo que a de contra-argumentação e a de compensação por acréscimo de novo argumento ocorrem nos dois séculos. Em (94), temos uma ocorrência exemplificativa da estratégia de contra-argumentação.

(95) Com base em fatores como a imensa riqueza petrolífera e elevadas reservas internacionais, agências conferiram aos russos o "investment grade", status de pouquíssimo risco. Do ponto de vista estritamente financeiro, a decisão faz sentido.

Se esse "upgrade" no entanto significa também que o país disporia de estabilidade e transparência institucional em níveis suficientes para tranquilizar os donos do dinheiro volátil global, a avaliação é duvidosa. (21FSP, nov.03)

Em (95), no primeiro período, a relação de contra-argumentação é estabelecida no domínio epistêmico, pois o fato de o investimento ser rentável do ponto de vista financeiro favorece a conclusão de que o investimento não apresente nenhum risco. Essa conclusão se choca com a informação da segunda oração, de que o investimento apresenta riscos.

\subsubsection{Porém}

O advérbio juntivo porém, segundo Hoauiss (2001), tem uso datado a partir do século XIII sob a forma poren. Segundo Said Ali (1964), porém advém do advérbio latino proinde e da sua forma abreviada proin, ambos com o sentido de "por isso". Na linguagem da Renascença, segundo o autor, porém passa por uma transformação semântica, deixando de significar "por isso", "por essa razão" e passando a significar "mas", "apesar disso", “contudo", ou seja, deixa de expressar a noção de causa para denotar oposição de ideias. Além da transformação semântica, porém deixa de ser um advérbio e passa a funcionar como conjunção.

Nos textos investigados, encontramos as seguintes grafias: porende, poren, por em, porê e porém. A grafia atual é encontrada já em textos do século XIII. 
O comportamento da frequência token de porém nos séculos XIII a XXI é ilustrado no gráfico 14. A partir desse gráfico, observamos que porém aumenta de frequência token em dois momentos, durante os séculos XIII a XV e durantes os séculos XVII a XX. O declínio entre o século XV e XVI pode estar relacionado ao processo de constituição do valor adversativo por que o item estava passando. Pode também, segundo Mattos e Silva (1984), estar relacionado ao desuso de pero, conjunção que apresenta a mesma trajetória sintáticosemântica de porém, no português. Já o declínio entre o século XX e XXI, como já foi explicado anteriormente, pode estar relacionado ao corpus jornalístico que foi utilizado na pesquisa.

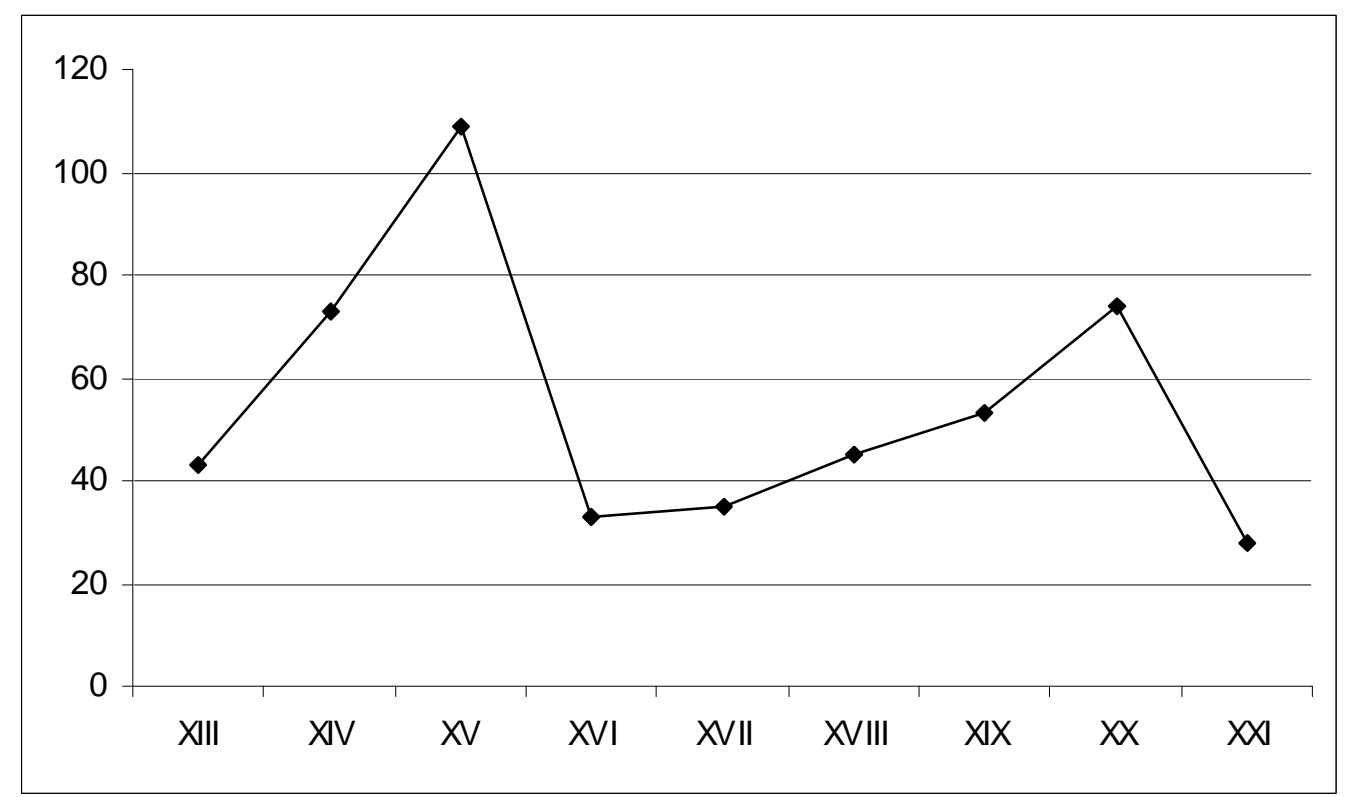

Gráfico 14: Frequência token de porém do século XIII ao XXI

Na tabela 18, à página seguinte, apresentamos as frequências token e type de porém nos séculos investigados. 


\begin{tabular}{|c|c|c|c|}
\hline Frequência & \multicolumn{3}{|c|}{ Frequência type } \\
\hline 493 & \multicolumn{3}{|c|}{04} \\
\hline & Categoria & Valor semântico & Totais \\
\hline & \multirow[t]{3}{*}{$\begin{array}{l}\text { Conjunção } \\
(33,6 \%)\end{array}$} & Conclusivo-explicativa & $\begin{array}{c}23 \\
(4,7 \%)\end{array}$ \\
\hline & & $\begin{array}{l}\text { Ambígua: conclusivo-explicativa/ adversa- } \\
\text { tiva }\end{array}$ & $\begin{array}{c}3 \\
(0,6 \%)\end{array}$ \\
\hline & & Adversativa & $\begin{array}{c}140 \\
(28,3 \%)\end{array}$ \\
\hline & \multirow{3}{*}{$\begin{array}{l}\text { Advérbio } \\
\text { juntivo } \\
(54 \%)\end{array}$} & Conclusivo-explicativo & $\begin{array}{c}92 \\
(18,7 \%)\end{array}$ \\
\hline & & $\begin{array}{l}\text { Ambíguo: conclusivo-explicativo/ adversa- } \\
\text { tivo }\end{array}$ & $\begin{array}{c}3 \\
(0,6 \%)\end{array}$ \\
\hline & & Adversativo & $\begin{array}{c}171 \\
(34,7 \%)\end{array}$ \\
\hline & \multirow[t]{2}{*}{$\begin{array}{l}\text { Advérbio } \\
(12,4 \%)\end{array}$} & Conclusivo-explicativo & $\begin{array}{c}46 \\
(9,4 \%)\end{array}$ \\
\hline & & Reforço & $\begin{array}{c}15 \\
(3 \%)\end{array}$ \\
\hline & & Total & $\begin{array}{c}493 \\
(100 \%)\end{array}$ \\
\hline
\end{tabular}

Tabela 18: Frequências token e type totais de porém na história do português (séc XIII a XXI)

Como se pode verificar na tabela acima, porém apresenta um total de 493 ocorrências entre os séculos XIII a XXI, distribuídas em 3 types sintáticos - advérbio, 12,4\%, advérbio juntivo, 54\%, conjunção, 33,6\%. Em relação aos types semânticos desempenhados por porém, há quatro types - conclusivo explicativo (32,8\%), adversativo (63\%), ambíguo $(1,2 \%)$ e reforço (3\%) -, distribuídos da seguinte maneira: o type conclusivo-explicativo ocorre predominantemente como advérbio juntivo $(18,7 \%)$ e ocorre também como conjunção $(4,7 \%)$ e como advérbio (9,4\%); o type adversativo ocorre como conjunção (28,3\%) e predominantemente como juntivo (34,7\%); o type ambíguo ocorre na mesma frequência, 0,3\%, tanto como conjunção quanto como advérbio juntivo; e o type reforço de um outro juntivo de mesmo valor ocorre como advérbio $(1,5 \%)$. 
Como se pode observar a partir dos percentuais apresentados na tabela 18, o type adversativo ocorre predominantemente no corpus investigado, correspondendo a $63 \%$ das ocorrências encontradas. Embora o uso como juntivo adversativo ainda detenha a maior percentagem, 34,7\%, o uso como conjunção adversativa já apresenta frequência próxima da desse uso juntivo, 28,3\%. Diante desses percentuais de usos adversativos e de uso como advérbio juntivo e como conjunção, podemos inferir que tanto a mudança semântica quanto a mudança sintática se encontram avançadas, em favor do uso adversativo e conjuncional, respectivamente, como veremos nas análises a seguir.

De (96) a (103), são apresentadas ocorrências exemplificativas de porém em cada um dos types sintático-semânticos.

\section{(96) Advérbio conclusivo-explicativo}

E quẽ quer que contra isto ueer ou fazer algũa cousa moyra porende e nõ seya leyxado uiuo. (13FR, p.4)

\section{(97) Reforço Adverbial}

As gallees d'Aragom como souberom que el-rrei de Castella desarmara a frota, desarmarom elles trinta gallees suas, e leixarom dez que andassem pello mar por fazer damno a algũus navios de Purtugall ou de Castella; e foi assi que o fezerom a algũus, mas poucos porém, e em pequenos navios. (15CDP, p.45)

\section{(98) Advérbio juntivo conclusivo-explicativo}

Esto foy quando o poboo de Ysrrael, que saya do Egito, duvidava entrar pelo mar ruyvo; e o tribo de Judá entrou primeiro depos Moyses, e porem mereceu o Reino. (14BMP, p.54)

\section{(99) Advérbio juntivo adversativo}

Não sei se poderei realizar, como tenho desejo, a exposição dogmatica das minhas idéas philosophicas. Quizera concentrar n'essa obra suprema toda a actividade dos annos que me restam a viver. Desconfio, porém, que não o conseguirei... (19CAQ, p.8)

\section{(100) Advérbio juntivo conclusivo-explicativo/adversativo}

$\mathrm{O}$ dia em que el Rey auia dauer sua rreposta, foi assijnado aaquelles senhores e leterados, no quall cada huu disse sua emtemçom, segundo a camtijdade de seu emtemder e saber, nom porem afastados de huu proposito. (15CTC, p.9)

\section{(101) Conjunção conclusivo-explicativa}

Porque semelhante amor quall el-rrei dom Pedro ouve a dona Enes rraramente he achado em algũua pessoa, porém disserom os antiigos que nẽhũu he tam verdadeiramente amado como aquell cuja morte nom tira da memoria o grande espaço do tempo. (15CDP, p.77) 
(102) Conjunção adversativa

Além disso, Deus também afirmou que nós deveríamos "crescer e nos multiplicarmos". Porém a própria igreja não segue essa afirmação divina ao exigir celibato para os padres. (21FSP, dez.04)

\section{(103) Conjunção conclusivo-explicativa/adversativa}

- Razõ darás a Deus da mha alma e a ti seera referida maldade de meus pecados se mi perlongares o baptismo, ca temo que per esta demorança caya em mããos daquel de que quero fogir e de cabo meter-m'ia a alma em seus laços. Eu fui maa e torpe e que deitey muyto ao mundo.(...) Porem te rogo que me faças outra vez nacer pela agua do sancto babtismo e dêsme em oferta a Deus. (14FS, p.19)

Na ocorrência exemplificativa (96), porém é usado com seu valor latino de origem, podendo ser parafraseado por por isso. É considerado advérbio fórico que traz uma circunstância de causa que predica sobre o verbo moyra (morra). Essa circunstância é estabelecida a partir da relação de foricidade do item que recupera o enunciado anterior $-e$ ver ou fazer alguma coisa contra isso.

Em (97), porém reforça o argumento defendido por meio da conjunção adversativa mas que o ataque a navios de Portugal ou Castela foi feito, mas, ao contrário de que o interlocutor esteja pensando, foi feito a poucos e pequenos navios. Esse uso, como demonstrado na tabela 18 , corresponde apenas a $3 \%$ do total de ocorrências encontradas.

Porém, em (98), ocupa posição medial, precedido da conjunção $e$, e estabelece a relação de conclusivo-explicativa entre os dois enunciados: a tribo de Judá e Moisés foram as primeiras a entrar no Mar Vermelho; logo mereceram o reino.

Na ocorrência (99), porém ocupa posição medial e estabelece apenas a relação semântica adversativa, enquanto a relação sintática acontece por justaposição. O argumento defendido pelo locutor é que, embora ele queira se dedicar a tal atividade todos os anos que ele ainda viverá, ele acredita que ele não conseguirá. A conclusão de não conseguir fazer tal atividade é contrária à conclusão de que ele irá fazer, uma vez que é algo a que ele almeja. 
Em (100), porém ocupa posição medial e permite duas leituras, uma conclusivoexplicativa e outra, adversativa. Essa ambiguidade ocorre devido à presença do elemento negativo não, que faz com que interpretemos o enunciado como "não por isso afastados de um propósito" (= o fato de os senhores e literatos terem dito sua intenção de acordo com o quanto entendia e sabia, não os afastaram por isso de um propósito). Segundo Said Ali (1964), esse contexto que permite a interpretação por não por isso, nem por isso foi o ponto de contato para porém adquirir valor adversativo. Numa leitura conclusivo-explicativa, a possível interpretação a ocorrência é que os senhores e literatos não estão afastados de um propósito pelo fato de terem dito suas intenções segundo seu entender e saber. Na leitura adversativa, por sua vez, temos que embora os senhores e literatos tenham dito suas intenções segundo seu entender e saber, eles não estão afastados de um propósito.

Em (101), o uso de porém é considerado conjuncional, pois o item ocupa posição inicial, promovendo articulação sintática e semântica. A leitura como conclusivo-explicativo é estabelecida a partir do fato de que, no primeiro enunciado, é exposto "o amor raro que Dom Pedro sentia por Dona Inês, que está morta" para, no segundo argumento, por causa de amor entre Dom Pedro e Dona Inês, "os antigos dizem que ninguém ama como aquele que a morte não tira da memória o grande espaço do tempo".

Em (102), ocorrência exemplificativa da sincronia atual, porém ocupa posição inicial, estabelecendo a relação sintática e semântica entre os dois enunciados. A leitura adversativa advém da contra-argumentação que há entre o fato de Deus afirmar que nós devemos crescer e multiplicar e a igreja, representante de Deus na terra, não seguir essa afirmação divina ao exigir o celibato para os padres.

Na ocorrência dada em (103), porém ocupa posição inicial e permite duas interpretações, uma, conclusivo-explicativa, em que o fato de o locutor ter sido uma pessoa má, desprezível e que se entregou a uma vida mundana é a razão pela qual ele roga a Deus 
que o faça nascer pela água do santo batismo; outra, adversativa, decorre da seguinte leitura: embora ele tenha sido uma pessoa má, desprezível e que se entregou a uma vida mundana, ele roga a Deus que o faça nascer de novo pela água do batismo.

Na tabela 19, expomos o percentual de ocorrências em cada uma das posições sintáticas - inicial, medial e final - ocupadas por porém.

\begin{tabular}{|c|c|c|}
\hline \multicolumn{2}{|c|}{ Posição/categoria } & Percentual \\
\hline \multirow[t]{3}{*}{ Inicial } & Advérbio & $\begin{array}{c}1 \\
(0,2 \%)\end{array}$ \\
\hline & $\begin{array}{l}\text { Advérbio } \\
\text { juntivo }\end{array}$ & $\begin{array}{c}3 \\
(0,6 \%) \\
\end{array}$ \\
\hline & Conjunção & $\begin{array}{c}166 \\
(33,7 \%)\end{array}$ \\
\hline \multirow[t]{2}{*}{ Medial } & Advérbio & $\begin{array}{c}42 \\
(8,5 \%)\end{array}$ \\
\hline & $\begin{array}{l}\text { Advérbio } \\
\text { juntivo }\end{array}$ & $\begin{array}{c}257 \\
(52,1 \%) \\
\end{array}$ \\
\hline \multirow[t]{2}{*}{ Final } & Advérbio & $\begin{array}{c}18 \\
(3,7 \%) \\
\end{array}$ \\
\hline & $\begin{array}{l}\text { Advérbio } \\
\text { juntivo }\end{array}$ & $\begin{array}{c}6 \\
(1,2 \%) \\
\end{array}$ \\
\hline & Total & $\begin{array}{c}493 \\
(100 \%)\end{array}$ \\
\hline
\end{tabular}

Tabela 19: Frequência das posições sintáticas de porém na história do português (séc. XIII a $\mathrm{XXI})$

Diante dos percentuais apresentados nessa tabela, constatamos que porém ocorre predominantemente na posição medial como advérbio juntivo, 52,1\%, seguida da posição inicial como conjunção, 33,7\%. Isso nos permite concluir que porém já se encontra num estágio de mudança sintática avançado em favor da cristalização na posição inicial, típica das conjunções prototípicas. Uma análise minuciosa dessa constatação pode ser feita pelo cruzamento dos fatores categoria e século, como se observa no gráfico 15. 


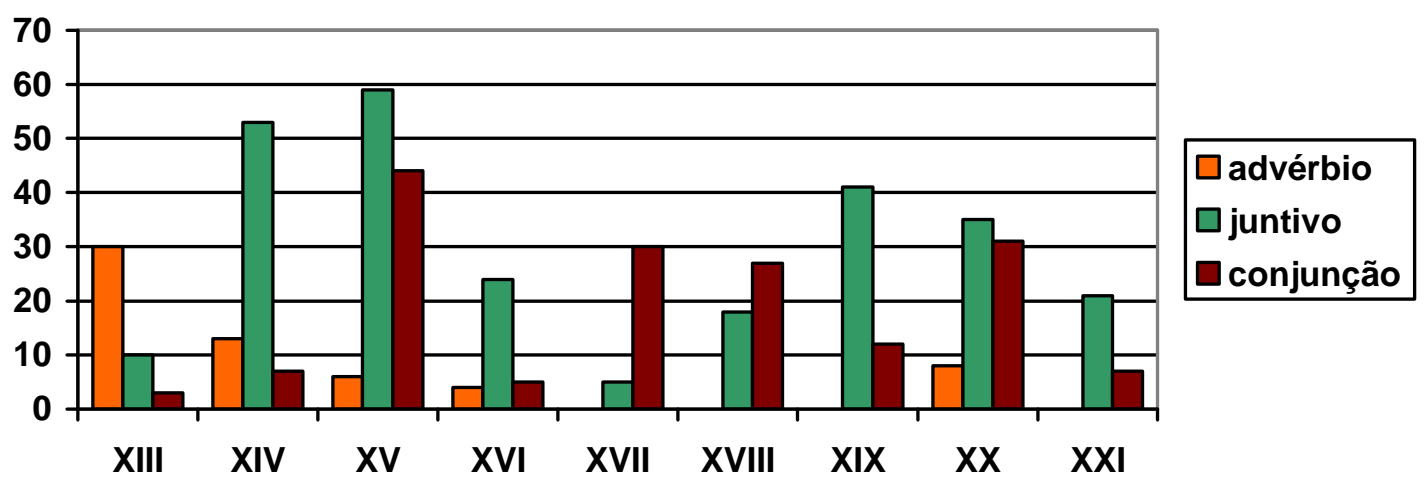

Gráfico 15: O desenvolvimento categorial de porém do século XIII ao XXI

O que se pode constatar, a partir do gráfico 15 , é que o uso adverbial, durante os séculos XIII a XVI, vai diminuindo, paulatinamente, desaparecendo durante os séculos XVII e XVIII, e reaparecendo, timidamente, no século XX na função de reforço adverbial, como veremos no gráfico 16.

Entre os séculos XIII e XVI e no século XX, há o convívio das três categorias advérbio, advérbio juntivo e conjunção. Nos séculos XVII e XVIII, há um percentual maior de usos conjuncionais, em relação aos usos juntivos, o qual diminui ao final do período investigado. Embora haja essa oscilação entre o uso juntivo e o conjuncional, pode-se dizer que a mudança, em favor de um uso também conjuncional, se instaura, de fato, a partir do século XVII, em que usos estritamente adverbiais se tornam raríssimos.

Diante dos resultados apresentados, uma possível escala de gramaticalização das categorias de uso de porém seria a dada em (104).

\section{ADVÉRBIO \\ (CONJUNÇÃO)}

Quanto ao aspecto semântico de porém, na tabela 18, constatamos que o item apresenta quatro types: (i) conclusivo-explicativo, (ii) adversativo, (iii) ambíguo entre 
conclusivo-explicativo e (iv) adversativo e reforço. No gráfico 16, apresentamos a distribuição dos valores semânticos de porém do século XIII a XXI.

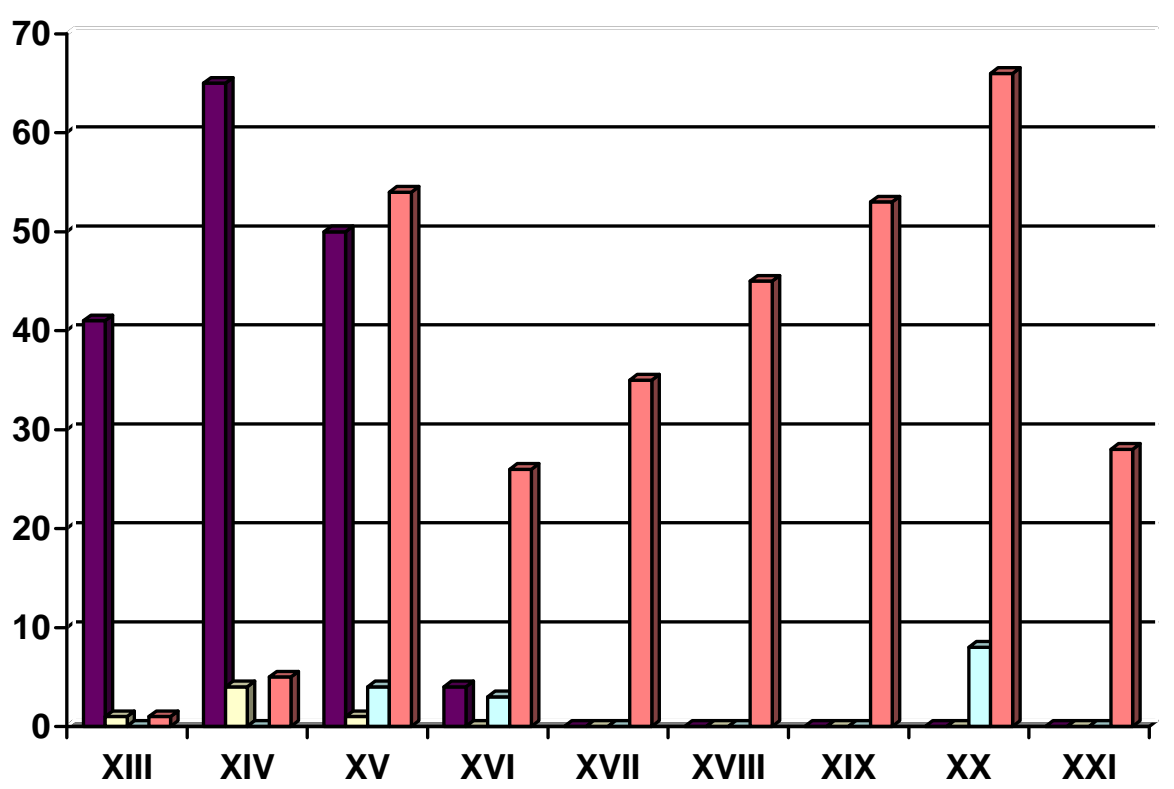

$\square$ conclusivo-explicativo $\square$ ambíguo $\square$ reforço $\square$ adversativo

Gráfico 16: Os valores semânticos de porém dos séculos XIII ao XXI

Como se observa, no gráfico 16, o valor original de porém, conclusivo-explicativo, ocorre até o século XVI, que, segundo Mattos e Silva (1984), foi o século em que porém se tornou adversativo e deixou de ser usado como conclusivo-explicativo. No corpus investigado, pode-se reconhecer o período dos séculos XIII ao XVI como o estágio de polissemia de porém, durante o qual se verificam todos os valores semânticos por ele experimentado. É a partir do século XVII que este estágio termina e que o item assume valor apenas adversativo. Depois de instaurada a mudança semântica do item, o uso adversativo aumenta a sua frequência entre os séculos XVI a XX, diminuindo no século XXI, devido ao fato da preferência por mas no texto jornalísticos, como já mencionado. Uma possível escala de gramaticalização das funções semânticas de porém seria: 
A mudança semântica, explicitada em (104), pode ser explicada por um viés metonímico ou metafórico. Pela metonímia, a proposta defendida por Said Ali (1964, p.187) de que "o ponto de contacto entre situações tão diversas está nas frases negativas, e foi naturalmente por elas que principiou a transição semântica", é comprovada, como veremos na tabela 20.

\begin{tabular}{l|l}
\hline \multicolumn{1}{c|}{ Contexto Negativo } & \multicolumn{1}{c}{ Frequência } \\
\hline Negação na primeira oração & $70(31,2 \%)$ \\
\hline Negação na segunda oração & $141(63 \%)$ \\
\hline Negação nas duas orações & $13(5,8 \%)$ \\
\hline Total & $224(100 \%)$
\end{tabular}

Tabela 20: O uso de porém em presença de elemento de negação ao longo da história do português (séc XIII a XXI)

O uso de porém em contexto negativo corresponde a 45,4\% das ocorrências investigadas. Com base nesses percentuais, o uso de porém, em contextos negativos, favoreceu a assimilação, via metonímia, do valor de negação, passando a expressar a negação do que tinha sido dito anteriormente. Em (105), apresentamos uma ocorrência que exemplifica esse contexto.

(106) Esta imperfeita execução da referida Lei durou até 9 de Março de 1832, época em que o Governo, autorisado pelo Artigo $15 \S 2 .^{\circ}$ da Lei de 15 de Novembro de 1831 , reformou a Academia pelos Estatutos daquella data. Então forão reunidas as duas Academias Militar , e de Marinha, segregando-se a maior parte do Curso philosophico , e creando-se Cadeiras de Construcção terrestre e naval : não se achando porêm conveniente a referida reunião, por Decreto de 22 de Outubro de 1833 se separárão de novo as duas Academias, conservando-se os Estatutos relativos á Militar, mas consideravelmente contrahidos. (19RNG, p.8)

Em (106), a relação adversativa é estabelecida entre ter feito a união da Academia Militar e da Marinha e a não conveniência dessa união. O uso do elemento não, na segunda oração, nega a inferência de que essa união feita anteriormente tivesse sido conveniente. $\mathrm{O}$ uso de porém, já como adversativo, colabora para estabelecer essa relação lógicoargumentativa. 
Por um viés metafórico, teríamos a atuação da escala espaço > tempo > (texto), proposta por Heine (1991). Como sabemos, espaço é uma categoria cognitiva que pode ser entendido como espaço do texto. De acordo com Rocha (2006), o pronome anafórico que compõe a forma porém, ende, perde a referência localizada no texto (domínio do espaço) e assume sentidos expressivos no texto, ao estabelecer a relação de contrajunção, uso eminentemente argumentativo e, portanto, mais abstrato que seu congênere anterior. $\mathrm{Na}$ escala abaixo, ilustramos a mudança, via metáfora.

(107)

\section{CONCLUSIVO-EXPLICATIVO > ESPAÇO}

ADVERSATIVO

TEXTO

Numa atuação conjunta da metáfora e da metonímia, teríamos que, enquanto aquela atua na abstratização do sentido do espaço, com auxílio do pronome anafórico ende, essa atua no contexto negativo que se mostra como favorável para instaurar a mudança. Uma escala que mostra a atuação dos dois mecanismos é apresentado em (108).

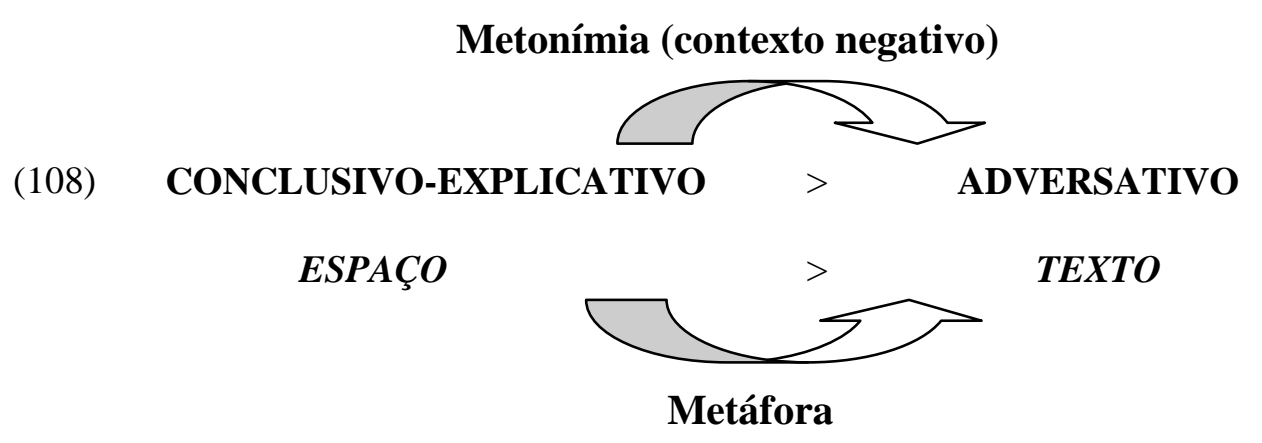

Em relação aos usos adversativos, controlamos as diferentes estratégias argumentativas empregadas por porém com valor adversativo, no decorrer dos séculos. Os resultados seguem na tabela 21 , a seguir. 


\begin{tabular}{|c|c|c|c|c|c|c|c|c|c|c|}
\hline Estratégias argumentativas & $\mathbf{X I I}$ & $\mathbf{X V}$ & $\mathbf{X V}$ & $\mathbf{X M}$ & XYI & XYII & $\mathbf{X X}$ & $\mathbf{X X}$ & $\mathbf{X X}$ & Total \\
\hline contra-argumentação & - & 3 & 31 & 10 & 13 & 14 & 23 & 34 & 9 & $\begin{array}{c}136 \\
(42 \%)\end{array}$ \\
\hline negação de inferência & - & 1 & 11 & 11 & 10 & 2 & 8 & 6 & 3 & $\begin{array}{c}52 \\
(16 \%)\end{array}$ \\
\hline $\begin{array}{l}\text { direção independente } \\
\text { (acréscimo de novo argumento) }\end{array}$ & - & - & 3 & 5 & 3 & 8 & 11 & 5 & 4 & $\begin{array}{c}39 \\
(12 \%)\end{array}$ \\
\hline $\begin{array}{l}\text { direção independente } \\
\text { (acréscimo de novo foco) }\end{array}$ & - & 1 & 2 & 1 & 4 & 4 & 4 & 10 & 4 & $\begin{array}{c}30 \\
(9,2)\end{array}$ \\
\hline $\begin{array}{l}\text { restrição } \\
\text { (acréscimo) }\end{array}$ & - & - & 4 & - & 4 & 7 & 2 & 1 & 1 & $\begin{array}{c}19 \\
(5,8)\end{array}$ \\
\hline $\begin{array}{l}\text { restrição } \\
\text { (pedido de informação) }\end{array}$ & - & - & - & - & - & 4 & - & 3 & - & $\begin{array}{c}7 \\
(2,1)\end{array}$ \\
\hline $\begin{array}{l}\text { restrição } \\
\text { (refutação) }\end{array}$ & - & - & 1 & - & - & - & - & 3 & - & $\begin{array}{c}4 \\
(1,2)\end{array}$ \\
\hline oposição & - & - & 2 & - & - & - & 1 & 1 & 3 & $\begin{array}{c}7 \\
(2,1)\end{array}$ \\
\hline marcador de surpresa & - & - & 2 & - & - & - & 1 & 2 & 1 & $\begin{array}{c}6 \\
(1,9) \\
\end{array}$ \\
\hline $\begin{array}{l}\text { direção independente } \\
\text { (acréscimo de novo tema) }\end{array}$ & - & - & - & - & - & 1 & 1 & 1 & 1 & $\begin{array}{c}4 \\
(1,2)\end{array}$ \\
\hline $\begin{array}{l}\text { compensação } \\
\text { (acréscimo de informação) }\end{array}$ & 1 & 1 & 1 & - & 1 & 5 & 1 & 5 & 2 & $\begin{array}{c}17 \\
(5,2)\end{array}$ \\
\hline $\begin{array}{l}\text { compensação } \\
\text { (exclusão de informação) }\end{array}$ & - & - & 2 & - & - & - & - & 1 & - & $\begin{array}{c}3 \\
(0,9)\end{array}$ \\
\hline $\begin{array}{l}\text { compensação } \\
\text { (substituição de informação) }\end{array}$ & 1 & - & 1 & - & - & - & 1 & - & - & $\begin{array}{c}3 \\
(0,9)\end{array}$ \\
\hline Frequência token & 2 & 6 & 60 & 27 & 35 & 45 & 53 & 72 & 28 & $\begin{array}{c}326 \\
(100)\end{array}$ \\
\hline Frequência type & 2 & 4 & 11 & 4 & 6 & 8 & 10 & 12 & 9 & 13 \\
\hline
\end{tabular}

Tabela 21: Frequência token e type totais de porém (adversativo) na história do português (séc XIII a XXI)

Como se verifica na tabela 21, a estratégia mais recorrente, na análise frequencial, como ocorreu nos demais itens, é a de contra-argumentação, usada em $42 \%$ das ocorrências investigadas. Na análise por século, observamos que o aumento das manobras argumentativas e o aumento da frequência token de porém é diretamente proporcional, corroborando com a hipótese de Bybee (2003) e Heine e Kuteva (2007). Observe-se a esse respeito que a tendência de fato é a de que maior é o número de funções quando é maior o número de ocorrências, como mostram os séculos XV (11/60), XIX (10/53) e XX (12/72).

Em (109), exemplificamos o uso de porém na estratégia de contra-argumentação. 
(109) E foram conversar na porta do Comércio e Indústria, à espera dos jornais. Só que agora estavam de cima, já bem menos numerosos, porém, mais vivazes e argumentadores, por gozarem das regalias da posição de oposição. (20GN, p.169)

Nessa ocorrência, estabelece-se a relação de contra-argumentação entre a conclusão que se faz a partir do primeiro enunciado - de que como eles estavam em uma quantidade menor, eles não seriam tão argumentadores - e a conclusão do segundo - de que eles, pelo contrário, são mais vivazes e argumentadores. A conclusão final tende para a conclusão defendida no segundo enunciado.

\subsection{Grupo de fatores pouco relevantes na análise dos juntivos}

$\mathrm{Na}$ análise apresentada para porém, contudo, entretanto, todavia e no entanto, na seção 4.2, alguns grupo de fatores não foram analisados, por se mostrarem pouco relevantes, uma vez que não serviram para diferenciar funções semânticas e categorias. Esses grupos são: nível de articulação, tipo de negação e correlação modo-temporal entre as orações.

O grupo de fator nível de articulação apresentou como altamente frequente, para todos os juntivos, o fator sentenças ou porções textuais independentes. Abaixo, nas tabelas (22) e (23), exemplificamos a frequência token extraída do cruzamento dos grupos nível de articulação X função semântica e nível de articulação X categoria, respectivamente. 


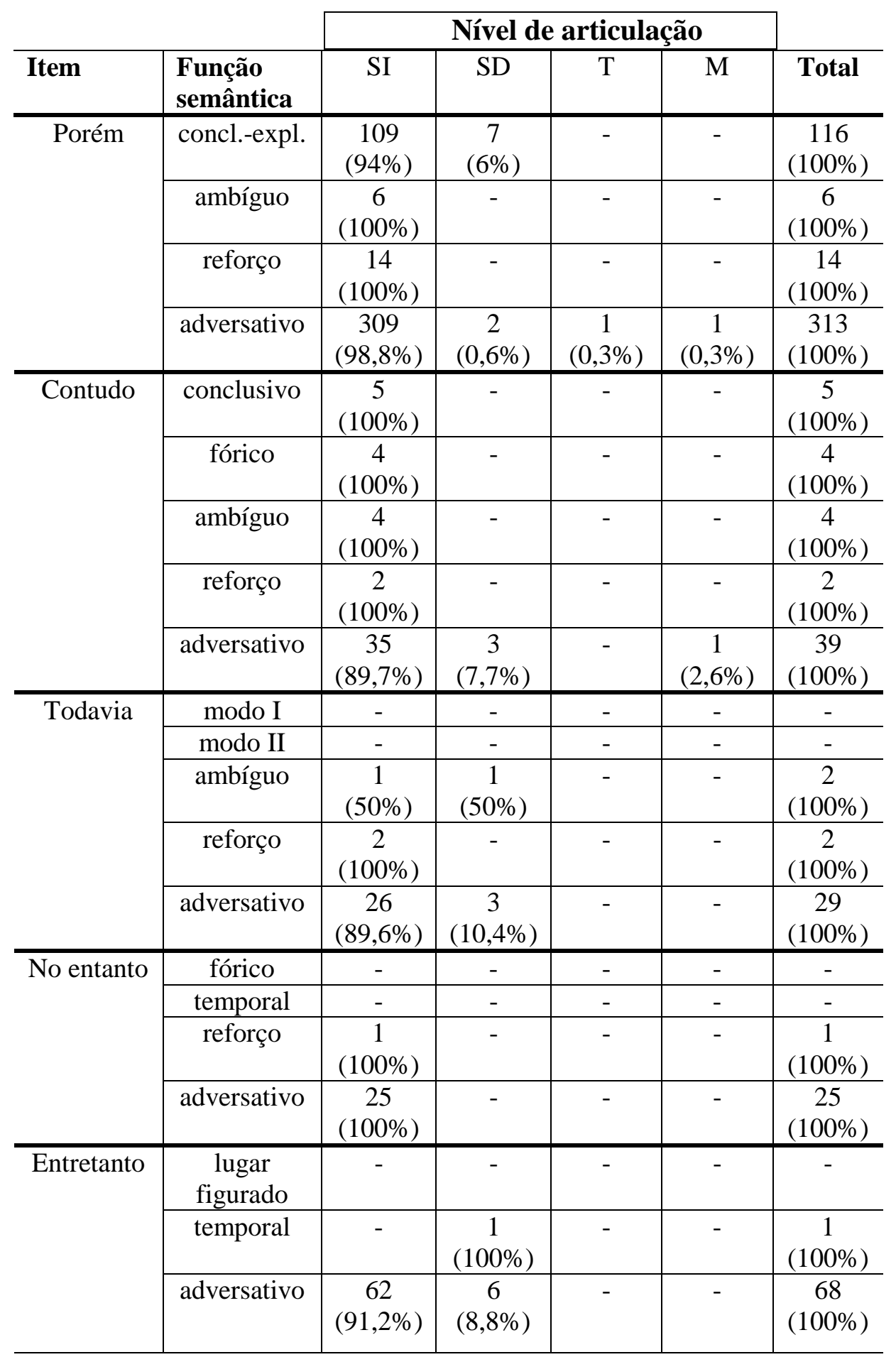

Tabela 22: As funções semânticas dos juntivos distribuídas nos níveis de articulação

De acordo com os percentuais apresentados na tabela acima, concluímos que não há nenhuma distinção entre função semântica e nível de articulação, pois, em todas as funções, a articulação predominante é entre sentenças ou porções textuais independentes. Em relação ao 
item porém, embora a articulação que predomine é a já apontada para os outros itens, esse item, na função adversativa, apresenta os quatro tipos de articulação, o que permite concluir que, devido ao estágio de gramaticalização avançado, em relação às categorias semânticas, o item não impõe restrição, quanto ao nível de articulação.

\begin{tabular}{|c|c|c|c|c|c|c|}
\hline \multirow[b]{2}{*}{ Item } & \multirow[b]{2}{*}{ Categoria } & \multicolumn{4}{|c|}{ Nível de articulação } & \multirow[b]{2}{*}{ Total } \\
\hline & & SI & SD & $\mathrm{T}$ & $\mathrm{M}$ & \\
\hline \multirow[t]{3}{*}{ Porém } & ADV & $\begin{array}{c}15 \\
(100 \%)\end{array}$ & - & - & - & $\begin{array}{c}15 \\
(100 \%)\end{array}$ \\
\hline & JUN & $\begin{array}{c}256 \\
(96,6 \%)\end{array}$ & $\begin{array}{c}9 \\
(3,4 \%)\end{array}$ & - & - & $\begin{array}{c}265 \\
(100 \%) \\
\end{array}$ \\
\hline & $\mathrm{CONJ}$ & $\begin{array}{c}165 \\
(98,8 \%) \\
\end{array}$ & - & $\begin{array}{c}1 \\
(0,6 \%) \\
\end{array}$ & $\begin{array}{c}1 \\
(0,6 \%) \\
\end{array}$ & $\begin{array}{c}167 \\
(100 \%) \\
\end{array}$ \\
\hline \multirow[t]{3}{*}{ Contudo } & $\mathrm{ADV}$ & $\begin{array}{c}7 \\
(100 \%) \\
\end{array}$ & - & - & - & $\begin{array}{c}7 \\
(100 \%) \\
\end{array}$ \\
\hline & JUN & $\begin{array}{c}28 \\
(87,5 \%)\end{array}$ & $\begin{array}{c}3 \\
(9,4 \%)\end{array}$ & - & $\begin{array}{c}1 \\
(3,1 \%)\end{array}$ & $\begin{array}{c}32 \\
(100 \%)\end{array}$ \\
\hline & $\mathrm{CONJ}$ & $\begin{array}{c}15 \\
(100 \%) \\
\end{array}$ & - & - & - & $\begin{array}{c}15 \\
(100 \%) \\
\end{array}$ \\
\hline \multirow[t]{3}{*}{ Todavia } & ADV & $\begin{array}{c}2 \\
(100 \%)\end{array}$ & - & - & - & $\begin{array}{c}2 \\
(100 \%)\end{array}$ \\
\hline & JUN & $\begin{array}{c}18 \\
(81,8 \%)\end{array}$ & $\begin{array}{c}4 \\
(18,2 \%)\end{array}$ & - & - & $\begin{array}{c}22 \\
(100 \%)\end{array}$ \\
\hline & CONJ & $\begin{array}{c}9 \\
(100 \%)\end{array}$ & - & - & - & $\begin{array}{c}9 \\
(100 \%)\end{array}$ \\
\hline \multirow[t]{3}{*}{ No entanto } & $\mathrm{ADV}$ & $\begin{array}{c}1 \\
(100 \%)\end{array}$ & - & - & - & $\begin{array}{c}1 \\
(100 \%)\end{array}$ \\
\hline & JUN & $\begin{array}{c}13 \\
(100 \%)\end{array}$ & - & - & - & $\begin{array}{c}13 \\
(100 \%)\end{array}$ \\
\hline & $\mathrm{CONJ}$ & $\begin{array}{c}12 \\
(100 \%)\end{array}$ & - & - & - & $\begin{array}{c}12 \\
(100 \%) \\
\end{array}$ \\
\hline \multirow[t]{3}{*}{ Entretanto } & ADV & - & $\begin{array}{c}1 \\
(100 \%)\end{array}$ & - & - & $\begin{array}{c}1 \\
(100 \%)\end{array}$ \\
\hline & JUN & $\begin{array}{c}39 \\
(86,7 \%) \\
\end{array}$ & $\begin{array}{c}6 \\
(13,3 \%) \\
\end{array}$ & - & - & $\begin{array}{c}45 \\
(100 \%)\end{array}$ \\
\hline & $\mathrm{CONJ}$ & $\begin{array}{c}23 \\
(100 \%)\end{array}$ & - & - & - & $\begin{array}{c}23 \\
(100 \%)\end{array}$ \\
\hline
\end{tabular}

Tabela 23: As categorias sintáticas dos juntivos distribuídas nos níveis de articulação

Diante dos percentuais apresentados na tabela 23 , também constatamos a pouca relevância do nível de articulação para distinção entre as categorias, ou seja, em todas as 
categorias, os itens articulam, preferencialmente, sentenças ou porções textuais independentes.

Um outro grupo de fator que não se mostrou relevante foi tipo de negação, pois a maioria dos casos de negação ocorre com negação explícita, como pode ser observado na ocorrência exemplificativa (110).

(110) Além disso, Deus também afirmou que nós deveríamos "crescer e nos multiplicarmos". Porém a própria igreja não segue essa afirmação divina ao exigir celibato para os padres.

Em (110), a negação ocorre na segunda oração e é explicitada por meio do elemento negativo não que, juntamente com porém, estabelece a relação de negação de inferência.

Quanto ao grupo correlação modo-temporal entre as orações, encontramos mais de 60 correlações para todos os itens considerados, o que dificulta expor os dados estatísticos para cada um dos itens. Entretanto o que observamos de comum entre eles é que prevalece, em todos os casos, a correlação presente do indicativo com presente do indicativo, que pode ser explicada pela seguinte formulação de base icônica: a marcação temporal dos enunciados articulados reflete o tempo da articulação dos argumentos, ou seja, o momento sempre presente do ato de fala.

Em relação às diferentes correlações encontradas, podemos concluir que, por estarem avançando na escala de gramaticalização rumo a uma função adversativa, os itens, em geral, não impõem restrições sobre a correlação modo-temporal, embora haja uma tendência de articular dois enunciados no presente do indicativo, respeitando-se o caráter de maior subjetivização desses usos adversativos, como quisemos expressar com a formulação expressa no parágrafo anterior. 


\subsection{Análise comparativa de porém, contudo, todavia, entretanto e no entanto}

Na seção 4.2, analisamos os itens adversativos, a fim de depreendermos o processo de mudança sintática, semântica e pragmática desses itens nas sincronias investigadas. Para tanto, levamos em consideração vários fatores que permitiram investigar a mudança. Nesta seção, cumprindo um dos objetivos deste trabalho, apresentamos análise comparativa que permite averiguar a ordem de emergência do uso conjuncional dos itens investigados, para, num segundo momento, propormos uma escala de gramaticalidade onde eles possam ser situados. Para essa análise, consideraremos dois fatores principais: relação semânticodiscursiva e categoria do item.

No gráfico 17, abaixo, apresentamos, conjuntamente, os itens investigados, a fim de compararmos os diferentes comportamentos ao longo dos séculos estudados.

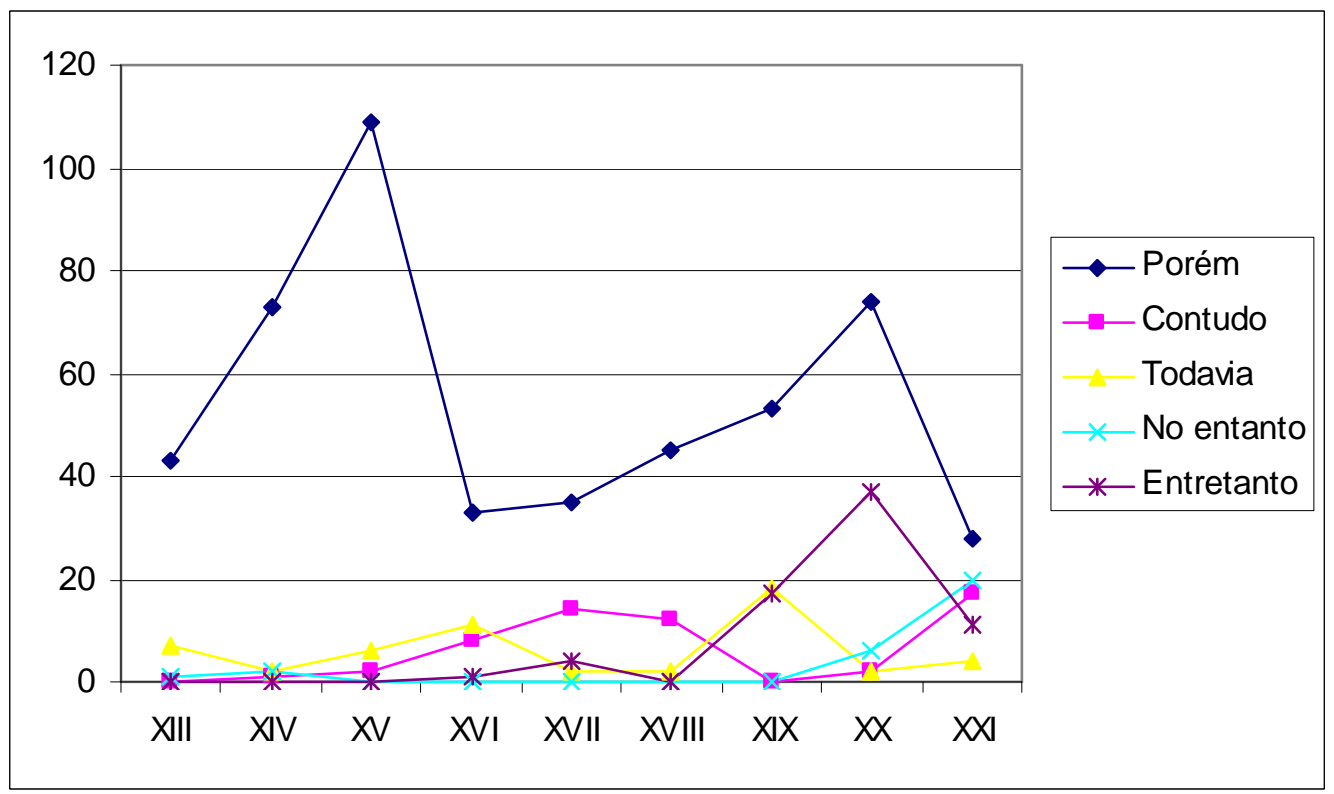

Gráfico 17: A trajetória dos itens investigados na história da língua portuguesa

Como se observa, porém, independentemente do valor contextual, é a forma que destaca das demais em todas as sincronias. As formas contudo e todavia se destacam timidamente, em termos de frequência, até o século XVIII. Em termos de frequência de uso, pode-se afirmar que a constituição do paradigma das adversativas, tal como ele se apresenta 
no PB atual, é relativamente recente, mais especificamente, a partir do século XXI, uma vez que é somente neste século que as formas apresentam comportamento pouco mais equilibrado.

Uma análise minuciosa, conjuntamente, dos itens nos séculos investigados, levando em consideração sua categoria e função semântica, nos permitirá estabelecer o século em que o valor mais gramaticalizado - conjuncional adversativo - emergiu para cada item e a relação entre emergência do valor mais gramaticalizado e frequência de uso sincronicamente. Para tanto, vejamos a tabela 24 , a seguir, que focaliza a categoria sintática e a relação adversativa de cada item.

\begin{tabular}{c|c|c|c|c|c|c|c|c|c|c}
\hline \multirow{2}{*}{ Item } & \multirow{2}{*}{ Cat. } & \multicolumn{10}{|c}{ Séculos } \\
\cline { 3 - 11 } & & XIII & XIV & XV & XVI & XVII & XVIII & XIX & XX & XXI \\
\hline \multirow{2}{*}{ Porém } & JUN & 1 & 4 & 27 & 21 & 5 & 18 & 41 & 35 & 21 \\
\cline { 2 - 11 } & CONJ & - & - & 28 & 5 & 30 & 27 & 12 & 31 & 7 \\
\hline \multirow{2}{*}{ Contudo } & JUN & - & 1 & - & 3 & 7 & 2 & - & 1 & 14 \\
\cline { 2 - 11 } & CONJ & - & - & - & 1 & 4 & 3 & - & 1 & 2 \\
\hline \multirow{2}{*}{ Todavia } & JUN & 1 & - & 1 & 2 & 1 & 2 & 13 & 2 & 1 \\
\cline { 2 - 10 } & CONJ & - & - & - & 1 & - & - & 2 & - & 3 \\
\hline \multirow{2}{*}{ Entretanto } & JUN & - & - & - & - & 1 & - & 9 & 32 & 3 \\
\cline { 2 - 10 } & CONJ & - & - & - & - & 2 & - & 8 & 5 & 8 \\
\hline \multirow{2}{*}{ No entanto } & JUN & - & - & - & - & - & - & - & 2 & 11 \\
\cline { 2 - 10 } & CONJ & - & - & - & - & - & - & - & 3 & 9 \\
\hline
\end{tabular}

Tabela 24: A relação adversativa para os diferentes itens na história da língua portuguesa

De acordo com os dados apresentados na tabela acima, observamos que o valor juntivo adversativo é o que mais se destaca para todas as formas. Há, no entanto, em alguns séculos, uma frequência maior do valor conjuncional adversativo, como se verifica para porém (séculos XV, XVII e XVIII), para contudo (século XVIII), para no entanto (século $\mathrm{XX)}$ e para todavia e entretanto (século XXI). A frequência maior do valor conjuncional adversativo em algumas sincronias pode evidenciar um processo de gramaticalização em curso, mais acelerado para alguns itens, como é o caso de porém, e mais lento para outros. A 
partir dessas considerações e dos dados apresentados na tabela, uma possível escala da emergência do valor conjuncional adversativo é apresentada abaixo.

(111) Ordem de emergência do uso conjuncional adversativo

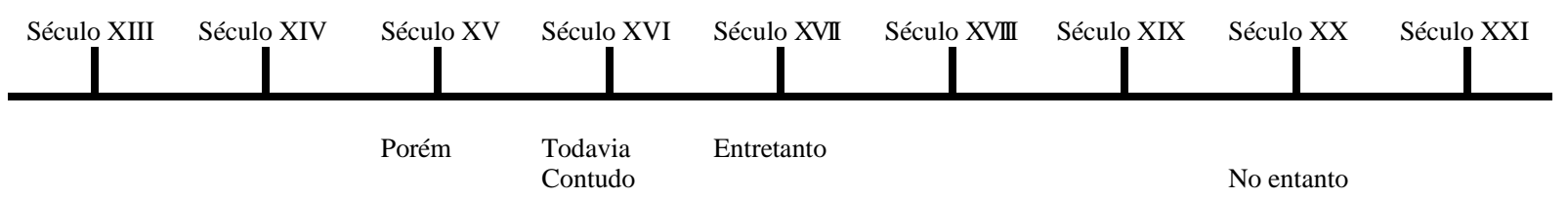

Se cruzarmos essas informações contidas na tabela 24 com a frequência de uso dos itens na sincronia atual, ${ }^{6}$ verificaremos que a relação forma mais gramaticalizada - forma mais frequente, postulada por Bybee (2003), precisa ser relativizada, no caso das adversativas. Comparemos, a esse respeito, a escala mostrada em (111) e a escala em (112) abaixo, que leva em conta a frequência do uso conjuncional dos itens no PB contemporâneo.

(112) Frequência do uso conjuncional adversativo no PB contemporâneo

\begin{tabular}{|c|c|c|c|}
\hline PORÉM & ENTRETANTO & $\begin{array}{c}\text { NO } \\
\text { ENTANTO }\end{array}$ & CONTUDO, TODAVI \\
\hline $\begin{array}{c}38 \\
\text { ocorrência: }\end{array}$ & $\begin{array}{c}13 \\
\text { ocorrências }\end{array}$ & $\begin{array}{c}12 \\
\text { ocorrências }\end{array}$ & $\begin{array}{c}3 \\
\text { Ocorrências }\end{array}$ \\
\hline
\end{tabular}

Como podemos verificar do confronto das duas escalas, o item porém é único adversativo a que se aplica a relação maior gramaticalidade, maior frequência de uso. Com os demais itens, ocorre exatamente o inverso, isto é, contudo e todavia, que são formas menos frequentes no PB contemporâneo, adquiriram valor conjuncional adversativo antes dos adversativos entretanto e no entanto, que são o segundo e o terceiro mais frequentes.

Diante desses resultados e da análise empreendida individualmente para os itens, concluímos que, no caso das adversativas, constatamos que a frequência no processo de mudança não seria a principal influência para a constituição do uso conjuncional adversativo.

\footnotetext{
${ }^{6}$ Consideramos, aqui, sincronia atual os séculos XX e XXI.
} 
Sendo assim, num primeiro momento, a emergência temporal dos usos mais gramaticalizados parece-nos plausível para explicar a gramaticalização dos itens adversativos na história do português, como ilustrada em (111).

A partir dessas conclusões, a escala (113) ilustra a gramaticalização dos juntivos adversativos na história do português.

(113) escala de gramaticalização dos itens adversativos na história do português.

PORÈM > TODAVIA, CONTUDO > ENTRETANTO > NO ENTANTO

Neves (1998), ao estabelecer a escala de gramaticalidade entre os adversativos, também considera porém como o mais gramaticalizado depois do prototípico mas, porém, para os demais itens, a autora não faz uma distinção na escala, apresentando-os conjuntamente. Essa falta de distinção entre os demais itens reconhecida por Neves e constatada por nós no confronto das escalas (112) e (113) leva-nos a ter de abrandar a conclusão dada na escala (113). Assim não parece sensato afirmar categoricamente a escala de gramaticalidade dos adversativos na história do português, uma vez que, por trabalharmos com dados efetivos da língua, a limitação do corpus é fator que influencia tanto na frequência de uso quanto na determinação temporal da constituição do valor conjuncional adversativo. 


\section{CONSIDERAÇÕES FINAIS}

$\mathrm{Na}$ presente pesquisa realizamos um estudo concomitante e comparativo da gramaticalização dos advérbios porém, contudo, todavia, entretanto e no entanto na história do português, a fim de analisar a trajetória de mudança advérbio > conjunção, pela qual os itens estão passando, de depreender os elementos que colaboraram para o surgimento da leitura de oposição dos itens e, além disso, de identificar fatores semântico-discursivos envolvidos nesse processo, observando, principalmente, as diferentes estratégias veiculadas por esses juntivos no estabelecimento de relações lógico-argumentativas. Destacamos, sincronicamente, o grau de gramaticalidade desses juntivos.

No primeiro capítulo, fizemos uma explanação do arcabouço teórico que guiou o trabalho, expondo as diferentes concepções sobre gramaticalização; a distinção entre unidade lexical e gramatical; a necessidade de um tratamento não dicotômico de sincronia e diacronia, uma vez que a investigação do nosso trabalho é baseada na junção das duas perspectivas; o princípio da unidirecionalidade; os mecanismos de metáfora, metonímia, reanálise e analogia. Nesse capítulo, apresentamos também trabalhos anteriores (BARRETO, 1999, ROCHA, 2006 e LONGHIN-THOMAZI, 2009) que abordaram os juntivos adversativos ou conjuntamente, como os trabalhos de Barreto, 1999 e Rocha, 2006, ou alguns deles, como Longhin-Thomazi, 2009, que enfoca a os aspectos semânticos da mudança de porém.

Diante das concepções apresentadas no capítulo I, os resultados alcançados nesta pesquisa serviram para reafirmar a concepção mais clássica da gramaticalização compreendida como uma mudança gradual que ocorre, em determinados contextos, fazendo com que construções lexicais assumam funções gramaticais. 
Dando continuidade a parte teórica do trabalho, no capítulo II, apresentamos a discussão que há na literatura acerca da proposta de incluir os juntivos estudados no rol das conjunções adversativas. De acordo com Neves (2000), porém, contudo, todavia, entretanto e no entanto são itens de caráter fluido que funcionam na oração como uma conjunção por estabelecer uma relação anafórica, mas não estão totalmente integrados ao paradigma das conjunções por não atenderem a determinadas propriedades. A esses itens, a autora dá o nome de advérbios juntivos, nomenclatura adotada nesse trabalho. Num segundo momento deste capítulo, abordamos o modo de articulação dentro das coordenadas, com enfoque nas coordenadas adversativas, apresentando um conjunto de características que permite definir uma estrutura coordenada adversativa, com base em Bally (1965), Carone (1988), Azeredo (1990), Perini (1995), Van Dijk (1977) e Dik (1989). Por fim, discutimos o tratamento da mudança semântica das conjunções, sob a perspectiva de Traugott e König (1991), Traugott (1982, 1999) e Sweetser (1990). Diante do ponto de vista desses autores, podemos concluir que os juntivos estudados são itens que estão seguindo a trajetória textual (valor anafórico) > expressivo. As postulações de Sweetser (1990) permitiram estabelecer uma discussão comparativa sobre o processo de mudança semântica de todavia, em português, tuttavia, em italiano e anyway, em inglês, a qual nos conduziu à conclusão de que o uso adversativo mais gramaticalizado de todavia é uma extensão do significado físico de via.

O capítulo III foi dedicado a relatar os procedimentos metodológicos desta pesquisa, começando pela composição dos corpora, constituído de textos de diversos gêneros dos séculos XIII a XXI. Os critérios de análise adotados foram apresentados em formato de grupo de fatores e consideraram aspectos formais e funcionais como: relação semântico-discursiva; posição do item no enunciado; co-ocorrência com outros juntivos; funcionamento semânticopragmático no valor adversativo; nível de articulação; presença e tipo de negação; correlação modo-temporal entre as orações; possibilidade de paráfrase por mas. No final 
deste capítulo, apresentamos nossa expectativa acerca dos fatores que permitiriam identificar e distinguir os usos adverbiais e conjuncionais dos itens.

$\mathrm{Na}$ análise de dados, primeiramente, foram descritos os aspectos sintáticos, semânticos e pragmáticos de cada item, focalizando a mudança de categoria, advérbio > advérbio juntivo (> conjunção), e a mudança semântica, a favor da constituição do valor adversativo. Das análises empreendidas, verificamos que o significado adversativo de porém, contudo, todavia se instaura antes do uso conjuncional adversativo, forma mais gramaticalizada que emerge primeiramente para porém, e depois para contudo e todavia, e, mais tardiamente, para entretanto e no entanto.

Uma hipótese levantada nesta pesquisa é a de que os juntivos adversativos adquiriram, primeiramente, valor adversativo, estabelecendo relação semântica entre orações, principalmente, em contextos em que co-ocorriam com conjunções prototípicas como e e mas, que, por serem consideradas conjunções por excelência, se responsabilizavam pela ligação sintática das orações. Levando em consideração essa hipótese, a trajetória de gramaticalização dos itens obedece à precedência da semântica sobre a sintaxe, corroborando postulados funcionalistas como os de Dik (1989) e Givón (1979).

As análises individuais de cada juntivo nos permitiram chegar à conclusão de que todos eles encontram-se em processo de gramaticalização, seguindo a trajetória advérbio > advérbio juntivo > conjunção. A análise comparativa dos itens baseada nos fatores relação semântico-discursiva e classe categorial do item nos permitiu verificar que porém, em todas as sincronias investigadas, se destacou como adversativo conjuncional, enquanto para os demais itens esse valor foi se estabelecendo mais tardiamente, ao longo dos séculos. Se considerarmos que o juntivo no entanto foi o último a adquirir o uso conjuncional adversativo, apenas no século XX, a constituição completa do paradigma das adversativas, em 
termos de frequência de uso, como vimos no capítulo IV, atinge certo equilíbrio somente a partir do século XXI.

Na definição da escala de gramaticalidade dos juntivos adversativos, observamos que há um embate entre a frequência de uso dos itens e o surgimento do uso conjuncional adversativo para cada um deles. Se determinarmos a escala de gramaticalidade, a partir da hipótese defendida por Bybee (2003) de que a forma mais gramaticalizada é a mais frequente, teríamos porém como mais gramaticalizada, entretanto e no entanto ocupando posições intermediárias na escala, sendo que adquiriram o uso conjuncional adversativo posterior a contudo e todavia. Diante dessa falta de coesão no paradigma das adversativas, consideramos que a forma mais gramaticalizada é aquela cujo uso conjuncional adversativo emergiu há mais tempo. Sendo assim, uma possível escala de gramaticalidade dos juntivos adversativos, proposta nesse trabalho é: porém > todavia, contudo > entretanto > no entanto. 


\section{REFERÊNCIAS BIBLIOGRÁFICAS}

AZEREDO, J. C. Iniciação à sintaxe português. 7.ed. Rio de Janeiro: Jorge Zahar Ed., 2001.

BARRETO, T. M. M. Gramaticalização das conjunções na história do português. 1999. Tese de doutorado - Universidade Federal da Bahia, Salvador (Bahia) UFBa, Salvador (Bahia).

BALLY, C. Linguistique Générale et Linguistique Française. 4.ed. Berne: Francke.

BECHARA, E. Moderna Gramática Portuguesa. 37.ed. Rio de Janeiro: Lucerna, 1999.

BYBEE, J., PERKINS, R., PAGLIUCA, W. The evolution of grammar. Chicago/London: The University of Chicago Press, 1994.

BYBEE, J. Cognitive processes in grammaticalization. In: THOMASELLO, M. (Ed.) The New Psychology of Language. vol. II. New Jersey: Lawrence Erlbaum Associates Inc., 2002.

BYBEE, J. Mechanisms of change in grammaticization: the role of frequency. In: JANDA, R.; JOSEPH, B. (Eds.) The handbook of historical linguistics. Oxford: Blackwell, 2003. p. 602-623.

CÂMARA JR, J. História e estrutura da língua portuguesa. 2. ed. Rio de Janeiro: Padrão, 1975.

CARONE, F. Subordinação e coordenação: confrontos e contrastes. São Paulo: Ática, 1988.

CASTILHO, C.M.M. Locativos, fóricos, articuladores discursivos e conjunções no português medieval. Gramaticalização de ende/en e de porende/porém. Filologia e linguística portuguesa, São Paulo, Humanitas/FFLCH/USP, n.6, p. 53-100, 1997.

Unidirecionalidade ou multidirecionalidade? O problema da gramaticalização. In: KOLLOQUIUM IN MÜNSTER 2003: DANS BRASILIANISCHE PORTUGIEISCH: PERSPEKTIVEN DER GEGENWÄRTIGEN FORSCHUNG, 1-18 de Janeiro, 2003, n.19, 1997, p.25-64.

CEGALlA, D. Novíssima gramática da língua portuguesa. São Paulo: Nacional, 1967.

CUNHA, A.G. Dicionário etimológico da Língua Portuguesa. 2.ed. Rio de Janeiro: Nova Fronteira, 1986.

DUCROT, O. Princípios de semântica linguística [Dizer e Não Dizer]. São Paulo: Cultrix, 1977. 
FRASER, B. Approaches to discourse particles. Elsevier Science, 2006.

GONÇALVES, S.C.L.; LIMA-HERNANDES, M.C.; CASSEB-GALVÃO, V.C. (Orgs.). Introdução à gramaticalização: princípios teóricos e aplicação. São Paulo: Parábola, 2007.

HAIMAN, J. Ritualization and the Development of Language. In: Wm. Pagliuca (Ed.). Perspectives on Grammaticalization. Amsterdam: John Benjamins, p.3-28.

HEINE, B. et al. Grammaticalization: a conceptual framework. Chicago: The University of Chicago Press, 1991.

On the role of context in grammaticalization. In: Wisher, I. (Ed.) New Reflections on Grammaticalization. PA, USA: John Benjamins Publishing Company, 2002.

HEINE, B.; KUTEVA, T. The Genesis of Grammar: A Reconstruction. Oxford: Oxford University Press, 2007.

HOPPER, P.; TRAUGOTT, E. Grammaticalization. Cambridge: Cambridge University Press, 2003.

HOUAISS, A.; VILlAR, M. Dicionário Houaiss da Língua Portuguesa. Rio de Janeiro: Objetiva, 2001.

KEWITZ, V. Gramaticalização e semanticização da preposição A e PARA no português do Brasil. Tese de doutorado. São Paulo: USP, 2007.

KOCH, I. Argumentação e linguagem. 2.ed. São Paulo: Cortez, 1987.

A inter-ação pela linguagem. 3.ed. São Paulo: Contexto, 1997.

LONGHIN-THOMAZI, S.R. A perífrase conjuncional "só que": invariância e variantes. Alfa, v.47, nº 2, p.139-152, 2003.

Corpus diacrônico do Português. UNESP/São José do Rio Preto. 2007. Disponível em: www.cdp.ibilce.unesp.br.

Grammaticalization of conjunctions. In: CASTILHO, A. T. (Org.) História do Português Paulista. Campinas: UNICAMP/Publicações IEL, 2009.

MATTOS e SILVA, R. V. Pero e Porém: mudanças em curso na fase arcaica da língua portuguesa. Boletim de Filologia, Lisboa: Centro de Linguística de Lisboa, v. II, Tomo XXIX, fasc. 1-4, 129-151, 1984. 
MEILLET, A. Linguistique historique et linguistique générale. Paris: Libraire Honoré Champion, 1948.

MÓDOLO, M. A gramaticalização das conjunções correlativas no português. Tese de doutorado. São Paulo: USP, 2004.

NEVES, M.H.M. A coordenação interfrasal em português. 1984. Tese (Livre-docência em Linguística) - UNESP.

O coordenador interfrasal mas - invariância e variantes. Alfa, v. 28, p. 21-42, 1984b.

A gramática funcional. São Paulo: Martins Fontes, 1997.

NEVES, M.H.M. A gramaticalização e a articulação de orações. Estudos linguísticos, p. 46$56,1998$.

Gramática de usos do português. São Paulo: Editora UNESP, 2000.

NUNES, J.J. Compêndio de gramática histórica portuguesa. 8.ed. Lisboa: Livraria Clássica Editora, 1975.

PERINI, M. Gramática descritiva do português. 2.ed. São Paulo: Ática, 1995.

PEZATTI, E. G.; LONGHIN-THOMAZI, S. R. As construções coordenadas. In: ILARI, R.; NEVES, M.H.M. (Orgs.) Gramática do português culto falado no Brasil - classes de palavras e processos de construção. Campinas (SP): Editora da Unicamp, p. 865-932, 2008.

ROCHA, A.P.A. Gramaticalização de conjunções adversativas em português: em busca da motivação conceptual do processo. 2006. Tese (Doutorado em Linguística) - Departamento de Letras do Centro de Teologia e Ciências Humanas, PUC-Rio, Rio de Janeiro.

Mudanças semânticas apresentadas por conjunções adversativas em português: o papel da categoria espaço. In: CASTILHO, A. T. (Org.) História do Português Paulista. Campinas: UNICAMP/Publicações IEL, 2009.

SAID ALI, M. S. Gramática histórica da língua portuguesa. 3.ed. São Paulo: Melhoramentos, 1964.

SILVA, T. M. A constituição do adversativo porém em dados do português arcaico. (Relatório de Iniciação Científica). UNESP/São José do Rio Preto, 2007.

SIMÕES, J. Sintaticização, discursivização e semanticização do gerúndio no português brasileiro. Tese de doutorado. São Paulo: USP, 2007. 
STALNAKER, R. Pragmatics. In: DAVIDSON, D.; HARMAN, G. (Ed.). Semantic of natural languages. Dordrecht: D. Reidel Publishing Company, 1972. p. 380-397.

SWEETSER, E. Grammaticalization and Semantic Bleaching. In: Proceedings of the Fourteenth Annual Meeting of the Berkeley Lingusitics Society. Eds. Axmaker, S., Jaisser, A., Singmaster, H, 1988.

From Etymology to pragmatics. Cambridge: Cambridge University Press, 1990.

TRAUGOTT, E. From propositional to textual and expressive meanings: some semanticpragmatic aspects of grammaticalization. In: Lehmman, C., Malkiel (Orgs.). Amsterdam studies in the theory and history of linguistic science. 24: 245-271, 1982.

From subjectification to intersubjectification. Paper presented at the Workshop on Historial Linguistics, Vancouver, Canadá, 1999.

TRAUGOTT, E.; HEINE, B. (orgs.) Approaches to grammaticalization. vol. 1. John Benjamins Publishing Company, 1991.

TRAUGOTT, E; KÖNIG, E. The semantic-pragmatics of grammaticalization revisited. In: TRAUGOTT, E., HEINE, B. (Orgs.) Approaches to grammaticalization. Vol. 1. John Benjamins Publishing Company, 1991.

VAN DIJK, T. A. Text and context. London and New York: Longman, 1977.

VOGT, C \& DUCROT, O. De magis a mas: uma hipótese semântica. In: VOGT, C. Linguagem, Pragmática e Ideologia. 2.ed. aum. São Paulo: Hucitec, 1989. 


\section{ANEXO \\ RELAÇÃO DE TEXTOS INVESTIGADOS}

\begin{tabular}{|c|c|}
\hline Sigla & Texto \\
\hline 13FR & $\begin{array}{l}\text { Foro Real de Afonso X [ ] Edição de José de Azevedo Ferreira. Lisboa: } \\
\text { Instituto Nacional de Investigação Científica, Vol. I, Edição de Estudo } \\
\text { Ling?te;stico, } 1987 .\end{array}$ \\
\hline 13LA & $\begin{array}{l}\text { Excertos de Legislação Antiga. Edição de J.J. Nunes. In: Crestomatia } \\
\text { Arcaica. 4.ed. Livraria Clássica Editora, s.d. }\end{array}$ \\
\hline 13DSG & $\begin{array}{l}\text { A demanda do Santo Graal [1220] Reprodução fac-similar e transcrição } \\
\text { crítica do códice } 2594 \text { da Biblioteca Nacional de Viena. Organizado por } \\
\text { Augusto Magne. Rio de Janeiro: Instituto Nacional do Livro, Vol. II, } 1970 .\end{array}$ \\
\hline $14 \mathrm{FS}$ & $\begin{array}{l}\text { Flos Sanctorum. In: MACHADO FILHO, A. V. L. Um flos sanctorum } \\
\text { trecentista em português. Brasilia: Universidade de Brasilia, } 2007 .\end{array}$ \\
\hline 14BMP & $\begin{array}{l}\text { Bíblia Medieval Portuguesa. Histórias d abreviado Testamento Velho, } \\
\text { segundo o Meestre das Historias Scolasticas. Texto apurado por Serafim } \\
\text { da Silva Neto. Rio de Janeiro: Instituto Nacional do Livro, } 1958 \text {. }\end{array}$ \\
\hline 14CGE & $\begin{array}{l}\text { Crónica Geral de Espanha de 1344. Edição crítica de Luís Filipe Lindley } \\
\text { Cintra. In Fontes Narrativas da História Portuguesa. Lisboa: Academia } \\
\text { Portuguesa da História. Vol. II, 1954; Vol. IV, } 1990 .\end{array}$ \\
\hline $15 \mathrm{BD}$ & $\begin{array}{l}\text { Boosco Deleitoso. MAGNE, A. Rio de Janeiro: Instituto Nacional do } \\
\text { Livro, vol. I, 1950. p. 3-13. }\end{array}$ \\
\hline $15 \mathrm{CDF}$ & $\begin{array}{l}\text { Crónica de D. Fernando. LOPES, Fernão. Introdução, seleção e notas de } \\
\text { Torquato de Sousa Soares. Coleção Clássicos Portugueses. Lisboa: } \\
\text { Livraria Clássica Editora, } 1945 \text {. }\end{array}$ \\
\hline $15 \mathrm{CFG}$ & $\begin{array}{l}\text { Crónica dos Feitos de Guiné. Azurara, Gomes Eanes. Trechos } \\
\text { selecionados por álvaro J. C. Pimpão. Coleção Clássicos Portugueses. } \\
\text { Lisboa: Livraria Clássica Editora, vol. II, 1942. }\end{array}$ \\
\hline $15 \mathrm{CTC}$ & $\begin{array}{l}\text { Crónica da Tomada de Ceuta. ZURARA, Gomes Eanes. Edição crítica } \\
\text { de Alfredo Pimenta. Lisboa: Livraria Clássica Editora, } 1942 .\end{array}$ \\
\hline $15 \mathrm{LC}$ & $\begin{array}{l}\text { Leal Conselheiro. D. DUARTE. Trechos escolhidos por F. C. Marques. } \\
\text { Coleção Clássicos Portugueses. Lisboa: Livraria Clássica Editora, } 1942 .\end{array}$ \\
\hline $15 \mathrm{LO}$ & $\begin{array}{l}\text { Livro dos Ofícios. CICERAM, Marco Tullio. Edição crítica, segundo o } \\
\text { ms. de Madrid, prefaciada, anotada e acompanhada de glossário, por } \\
\text { Joseph M. Piel. Coimbra: Por Ordem da Universidade, } 1948 \text {. }\end{array}$ \\
\hline $15 \mathrm{CC}$ & $\begin{array}{l}\text { A Carta de Pero Vaz de Caminha. CORTESAO, J. (ed.). Lisboa: } \\
\text { Portugalia, } 1967 .\end{array}$ \\
\hline $15 \mathrm{CDP}$ & Crónica de D. Pedro. LOPES, F. (Edizione critica, con introduzione e \\
\hline
\end{tabular}




\begin{tabular}{|c|c|}
\hline & $\begin{array}{l}\text { glossário a cura di Giuliano Macchi. Roma: Edizioni dell'Ateneo, } 1966 . \\
\text { pp. 119-121, 207-229. }\end{array}$ \\
\hline 16JA & $\begin{array}{l}\text { Livro de José de Arimateia. CASTRO, I. (ed.). Lisboa: Faculdade de } \\
\text { Letras de Lisboa, } 1984 .\end{array}$ \\
\hline $16 \mathrm{NB}$ & $\begin{array}{l}\text { Notícias do Brasil. SOUSA, G. S. (ed.). (Transcrição de Maria da Graça } \\
\text { Pericao). Lisboa: Publicacoes Alfa, } 1989 \text {. }\end{array}$ \\
\hline $16 \mathrm{CDA}$ & $\begin{array}{l}\text { Crônica del-Rei D. António. FRIAS, Pedro. Estudo e leitura de Mário } \\
\text { Alberto Nunes Costa. Acta Universitatis Conimbrigensis. Coimbra: } \\
\text { Coimbra Editora Ltda, } 1955 \text {. }\end{array}$ \\
\hline $16 \mathrm{CPJ}$ & $\begin{array}{l}\text { Cartas dos primeiros jesuítas do Brasil (1538-1553). SERAFIM LEITE, } \\
\text { S.I. Comissão do IV Centenário da Cidade de São Paulo, vol. I, s.d. }\end{array}$ \\
\hline $16 \mathrm{HSC}$ & $\begin{array}{l}\text { Historia da prouincia de Sãcta Cruz a que vulgarme[n]te chamamos } \\
\text { Brasil... G } \square \text { DAVO, Pero de Magalhães. Lisboa: Officina Antonio } \\
\text { Gonsalvez, } 1576 \text {. }\end{array}$ \\
\hline $16 \mathrm{CDM}$ & $\begin{array}{l}\text { Crônica do Felicíssimo Rei D. Manuel. GóIS, D. Nova edição conforme } \\
\text { a primeira de 1566. Parte I. Coimbra: Por Ordem da Universidade, } 1949 .\end{array}$ \\
\hline $16 \mathrm{CDJ} 3$ & $\begin{array}{l}\text { LETTERS OF JOHN III - king of Portugal. FORD, J. D. M. } \\
\text { Cambridge: Harvard University Press, 1931. Edição digital do Projeto } \\
\text { BIT-PROHPOR (Banco Informatizado de Textos do Programa para a } \\
\text { História da Língua Portuguesa), coordenado pela Prof }{ }^{\text {a. }} \text { Dr }^{\text {a. }} \text { Rosa Virgínia } \\
\text { Mattos e Silva, Instituto de Letras da Universidade Federal da Bahia. }\end{array}$ \\
\hline $17 \mathrm{CA}$ & $\begin{array}{l}\text { Corte na Aldeia, e Noites de Inverno. LOBO, Francisco Rodrigvez. } \\
\text { Oferecido ao Senhor Dom Dvarte. Lisboa: Pedro Crasbeeck, } 1619 .\end{array}$ \\
\hline 17FLS & $\begin{array}{l}\text { Frei Luis de Sousa. Trechos de várias obras selecionados por Alfredo } \\
\text { Pimenta. Coleção Clássicos Portugueses. Lisboa: Livraria Clássica } \\
\text { Editora, 1943. }\end{array}$ \\
\hline $17 \mathrm{HA}$ & $\begin{array}{l}\text { Historiografia de Alcobaça (Frey Bernardo de Brito e Frei Antonio } \\
\text { Brandão). Trechos escolhidos Alfredo Pimenta. Lisboa: Livraria Clássica } \\
\text { Editora, 1943. }\end{array}$ \\
\hline $17 \mathrm{LPG}$ & $\begin{array}{l}\text { Livro Primeiro do Governo do Brasil (1607-1633). Prefácio de J. C. de } \\
\text { Macedo Soares. Ministério das Relações Exteriores. Rio de Janeiro: Seção } \\
\text { de Publicações do Serviço de Documentação. }\end{array}$ \\
\hline $17 \mathrm{SS}$ & $\begin{array}{l}\text { Serman da Sexagésima. VIEIRA, P. Antonio. In: Magne (org) Sermões } \\
\text { de Padre Vieira. Reprodução facsimilada da edição de 1679. São Paulo: } \\
\text { Editora Anchietana, s.d }\end{array}$ \\
\hline 17JVC & $\begin{array}{l}\text { Jornada dos Vassalos da Coroa de Portugal. GUERREIRO, Padre } \\
\text { Bartolomeu. Coleção Rodolfo Garcia. Rio de Janeiro: Divisão de } \\
\text { Publicações e Divulgação, } 1966 .\end{array}$ \\
\hline $17 \mathrm{CBS}$ & $\begin{array}{l}\text { Cartas Baianas Setecentistas. In: LOBO, Tânia (org.) Cartas Baianas } \\
\text { Setecentistas. São Paulo: Humanitas /FFLCH, USP, 2001. }\end{array}$ \\
\hline
\end{tabular}




\begin{tabular}{|c|c|}
\hline $18 \mathrm{D}$ & $\begin{array}{l}\text { Directório, que se deve observar nas Povoações dos índios do Pará, e } \\
\text { Maranhaõ em quanto Sua Magestade naõ mandar o contrario. Lisboa, } \\
\text { Na Officina de Miguel Rodrigues, Impressor do Eminentíssimo Senhor } \\
\text { Cardial Patriarca. MDCCLVIII. }\end{array}$ \\
\hline $18 \mathrm{NA}$ & $\begin{array}{l}\text { Necessario Aviso acerca da Igreja e Doutrina dos Papas em Roma. } \\
\text { Amorosa e fielmente dado para a advertencia dos que estão na Ditta Igreja. } \\
\text { Pelos Missionários Inglezes em Madras. Calcutta, Impressa na Officina da } \\
\text { Missão. Ano MDCCLXXXV. }\end{array}$ \\
\hline $18 \mathrm{OS}$ & $\begin{array}{l}\text { A Ordem da Salvação ou A Doutrina Christaã brevemente em } \\
\text { perguntas e respostas declarada e provada com principaes testemunhos da } \\
\text { escritura sagrada. Tranquebar. Em índia Oriental na Costa de Coromandel. } \\
\text { Na Estampa dos Missionários delRey de Dennemarck. Anno } 1712 \text {. }\end{array}$ \\
\hline $18 \mathrm{UA}$ & $\begin{array}{l}\text { Do Uso, e Abuso das minhas Agoas de Inglaterra, pello inventor das } \\
\text { mesmas Agoas, J. de Castro Sarmento, doutor em Medicina, do Collegio } \\
\text { Real dos Médicos de Londres, e Sócio da Sociedade Real. Impresso em } \\
\text { Londres, Em Caza de Guilherme Strahan, anno MDCCLVI. }\end{array}$ \\
\hline $18 \mathrm{TM}$ & $\begin{array}{l}\text { Theorica verdadeira das Mares, conforme a philosophia do } \\
\text { incomparável cavalhero Issac Newton, pello Dr. Jacob de Casto Sarmento. } \\
\text { Impressa em Londres, anno MDCCXXXVII. }\end{array}$ \\
\hline $18 \mathrm{COPB}$ & $\begin{array}{l}\text { Cartas oficiais da Paraíba dos Séculos XVIII e XIX. Fonseca, Maria } \\
\text { Cristina de Assis (org.). João Pessoa: Idéia, } 2004 .\end{array}$ \\
\hline 19CAQ & $\begin{array}{l}\text { Cartas de Antero de Quental com um prefacio de Teixeira de Carvalho. } \\
\text { Coimbra: Imprensa da Universidade, } 1921 \text {. }\end{array}$ \\
\hline 19CGM & $\begin{array}{l}\text { Chronica Geral e Minuciosa do Império do Brazil. Desde a descoberta } \\
\text { do Novo Mundo ou America até anno de } 1879 \text {. Pelo Dr. Mello Moraes } \\
\text { (A.J. de). Rio de Janeiro: Dias da Silva J?, Typographo-editor, } 1879 \text {. }\end{array}$ \\
\hline 19DMA & $\begin{array}{l}\text { Discurso recitado pelo Exmo Presidente Miguel de Souza Mello e } \\
\text { Alvim, no dia } 07 \text { de janeiro de } 1842 \text {, por ocasião da abertura da } \\
\text { Assembléia Legislativa da Província de São Paulo. São Paulo: } \\
\text { Typographia Imperial de Silva Sobral, } 1812 \text {. }\end{array}$ \\
\hline 19IRP & $\begin{array}{l}\text { A Idéia Republicana no Pará. Coletânea de artigos publicados no Diário } \\
\text { de Notícias, do Pará, em 1988. Organizados por Lauro Sodré in: Crenças e } \\
\text { Opiniões. Belém: Typographia do Diário Oficial, } 1896 .\end{array}$ \\
\hline $19 \mathrm{RNG}$ & $\begin{array}{l}\text { Relatório da Repartição dos Negócios da Guerra, apresentado } \\
\text { Assembléia Geral Legislativa, em } 14 \text { de janeiro de 1843, pelo respectivo } \\
\text { Ministro e Secretário d?Estado José Clemente Pereira. Rio de Janeiro: Na } \\
\text { Typographia Nacional, } 1845 \text {. }\end{array}$ \\
\hline $19 \mathrm{RV}$ & $\begin{array}{l}\text { Relatório de viagem exploradora de Matto-Grosso ao Pará pelo rio } \\
\text { Xingu, apresentado ao Ministro da Guerra ? em } 1885 \text { ? pelo então Capitão } \\
\text { Francisco de Paula Castro. Revista ?O Arquivo?, vol. I. Cuiabá Fundação } \\
\text { J?Campos, } 1904 \text {. }\end{array}$ \\
\hline
\end{tabular}




\begin{tabular}{|c|c|}
\hline 19SPDD & $\begin{array}{l}\text { OLIVEIRA, Klebson. Textos escritos por africanos e afro-descendentes } \\
\text { na Bahia do século XIX: Fontes do nosso latim vulgar? 2003. v. } 2 . \\
\text { Dissertação (Mestrado em Letras) - Instituto de Letras, Universidade } \\
\text { Federal da Bahia, Salvador. }\end{array}$ \\
\hline \multirow{12}{*}{ 20BLA-CRO } & Gazeta de Notícias 2/8/1903 - PESSOAS. Eça de Queirós \\
\hline & Gazeta de Noticias 19/8/1900 - ZOLA \\
\hline & Gazeta de Notícias 5/10/1902 - JOSÉ DO PATROCINÍO \\
\hline & Gazeta de Notícias 8/3/1903 - CARLOS GOMES \\
\hline & Gazeta de Notícias 21711905 - ARTUR AZEVEDO \\
\hline & Gazeta de Notícias 25/10/1908 - EMÍLIO ROUÈDE \\
\hline & Correio Paulistano 13/6/1908 - LITERATURA. ALUÍSIO AZEVEDO \\
\hline & $\begin{array}{l}\text { Boitempo (A Falta que Ama) Carlos Drummond de Andrade. Editora } \\
\text { Sabiá Ltda, } 1968\end{array}$ \\
\hline & $\begin{array}{l}\text { Cronicas Efêmeras - Paulo Barrte } \\
\text { JOÃO DO RIO) JOÃO DO RIO NA REVISTA DA SEMANA - } 1916 \\
\text { EDITORA GIORDANO - SÃO PAULO - SP }\end{array}$ \\
\hline & $\begin{array}{l}\text { Um episódio em Porto Alegre ( Uma fada no front) } \\
\text { Rubem Braga Editora Record ( Rio de Janeiro 2002) - crônicas do ano } \\
1939\end{array}$ \\
\hline & $\begin{array}{l}\text { Os Filhos da Candinha Mario de Andrade. In: Obras completas de Mário } \\
\text { de Andrade. Livraria Martins Editôra, } 1942\end{array}$ \\
\hline & $\begin{array}{l}\text { Paulicéia - Ronda da Meia Noite } \\
\text { SYLVIO FLOREAL } 1^{a} \text { EDIÇÃO DEZEMBRO DE } 2002 \text { - BOITEMPO } \\
\text { EDITORIAL EDIÇÃO ORIGINAL - SÃO PAULO - } 1925\end{array}$ \\
\hline \multirow{2}{*}{ 20CE-C } & CE-C - Cartas Escolhidas \\
\hline & $\begin{array}{l}\text { Monteiro Lobato Ano do original: } 19591^{\circ} \text { e } 2^{\circ} \text { tomo, Editora Brasiliense: } \\
\text { São Paulo, } 1959 .\end{array}$ \\
\hline $20 \mathrm{GN}$ & Gazeta de Notícias. $1^{\text {a }}$ metade do século XX. \\
\hline 21FSP & Folha de São Paulo. ano: 2001 a 2009. \\
\hline
\end{tabular}


Autorizo a reprodução xerográfica para fins de pesquisa.

São José do Rio Preto, 18 de maio de 2010. 